Fall 1931

\title{
1931 Cedrus Yearbook
}

\section{Cedarville College}

Follow this and additional works at: https://digitalcommons.cedarville.edu/yearbooks

Part of the Higher Education Commons, Organizational Communication Commons, and the Public Relations and Advertising Commons

\section{Recommended Citation}

Cedarville College, "1931 Cedrus Yearbook" (1931). Yearbooks. 77.

https://digitalcommons.cedarville.edu/yearbooks/77

This Book is brought to you for free and open access by DigitalCommons@Cedarville, a service of the Centennial Library. It has been accepted for inclusion in Yearbooks by an authorized administrator of DigitalCommons@Cedarville. For more information, please contact digitalcommons@cedarville.edu. 



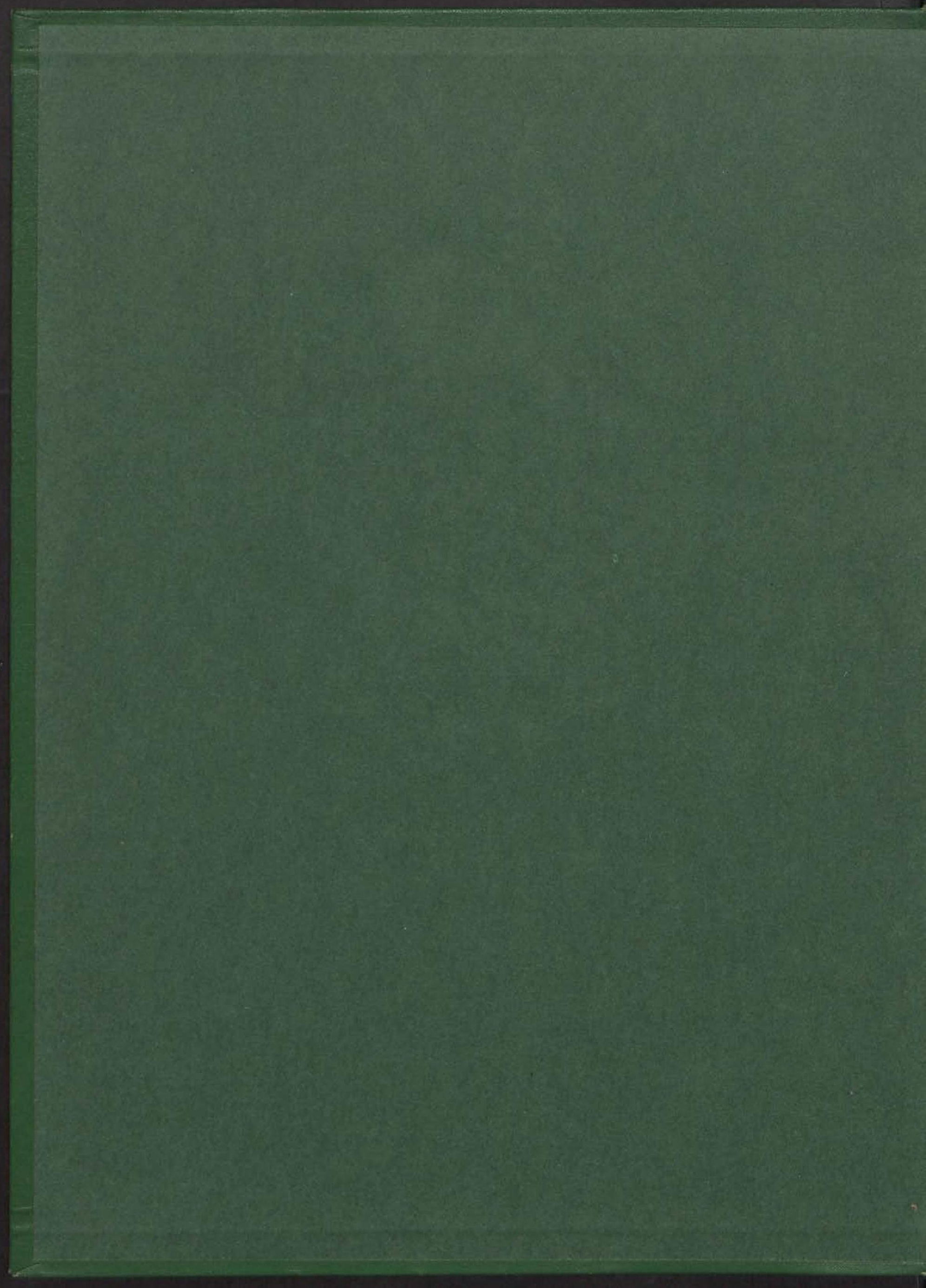




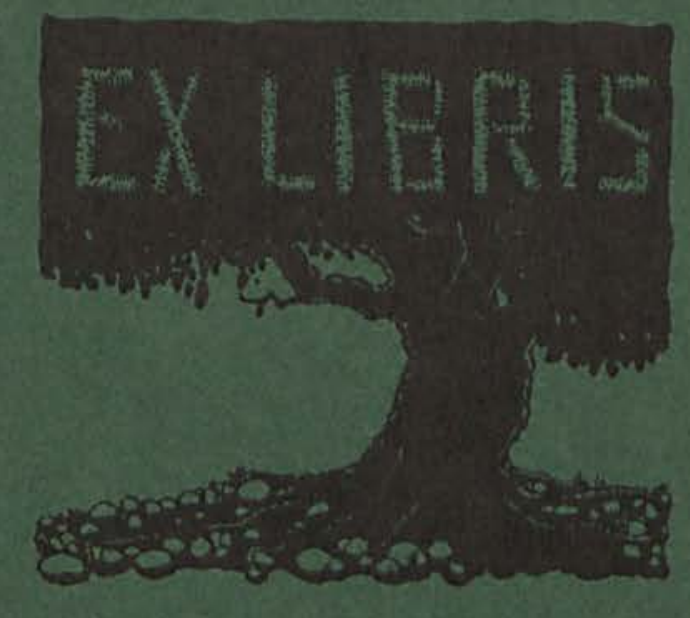

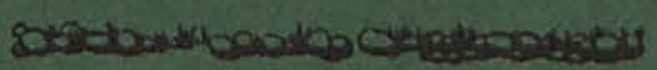




$$
\begin{aligned}
& \text { THE } 1931 \\
& \text { CEDRUS }
\end{aligned}
$$

PUBLISHED ACCORDING TO

THE STANDARDS

OF

THE STUDENT BODY

\author{
OF \\ CEDARVILLE COLLEGE
}

Published by

THE CEDRUS STAFF

Elected by

THE STUDENT BODY

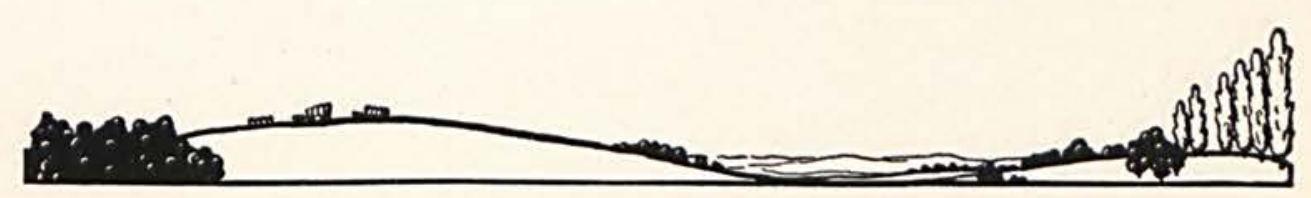




\section{Starting on a Journey}

Starting on a journey

Preparing for the ordeal

Winding our way onward

Searching for things which are ideal.

Conquering foes which are new

Searching for obstacles to abate

We do not carry a chip on our shoulder

Nor do we carry the spirit of hate

We carry only a search for knowledge

A search for something we cannot lose

We know we shall profit from this journey

So this is the course which we choose.

A. W. B. 


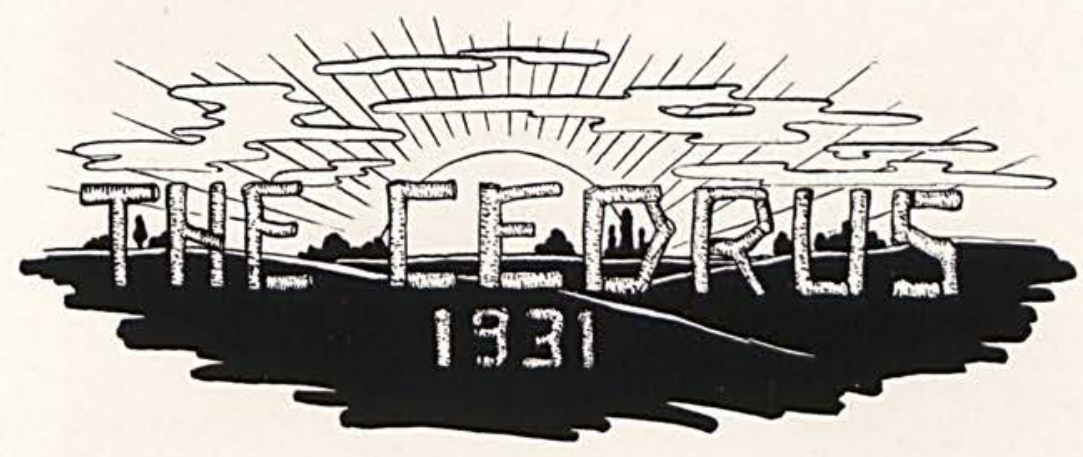




\section{F O R E W O R D}

WE seek life before us, unfolding its many allurments, influences and enjoyments. We wander into unknown and unheralded realms. This has been so in our college regime and it shall be so in our life to come. We are merely controlled by a higher element, playing our role in life.

We need guidance of a good, moral, Christian nature. These guiding influences take many forms not recognizable at times. We are thankful for these guiding principles, one of which is our dear school which boosts us upward. We shall try to portray for your approval some of the life existing around us which creates our very dear memories and guides us toward our goal.

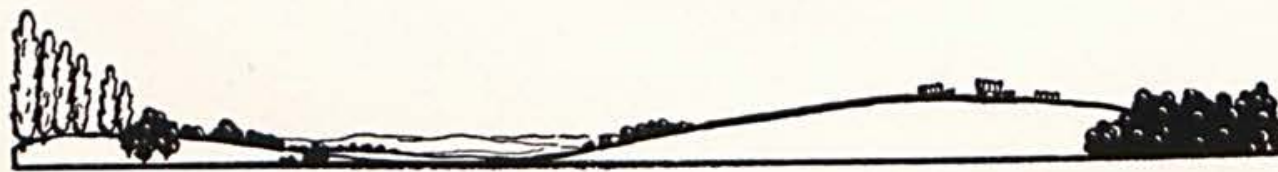




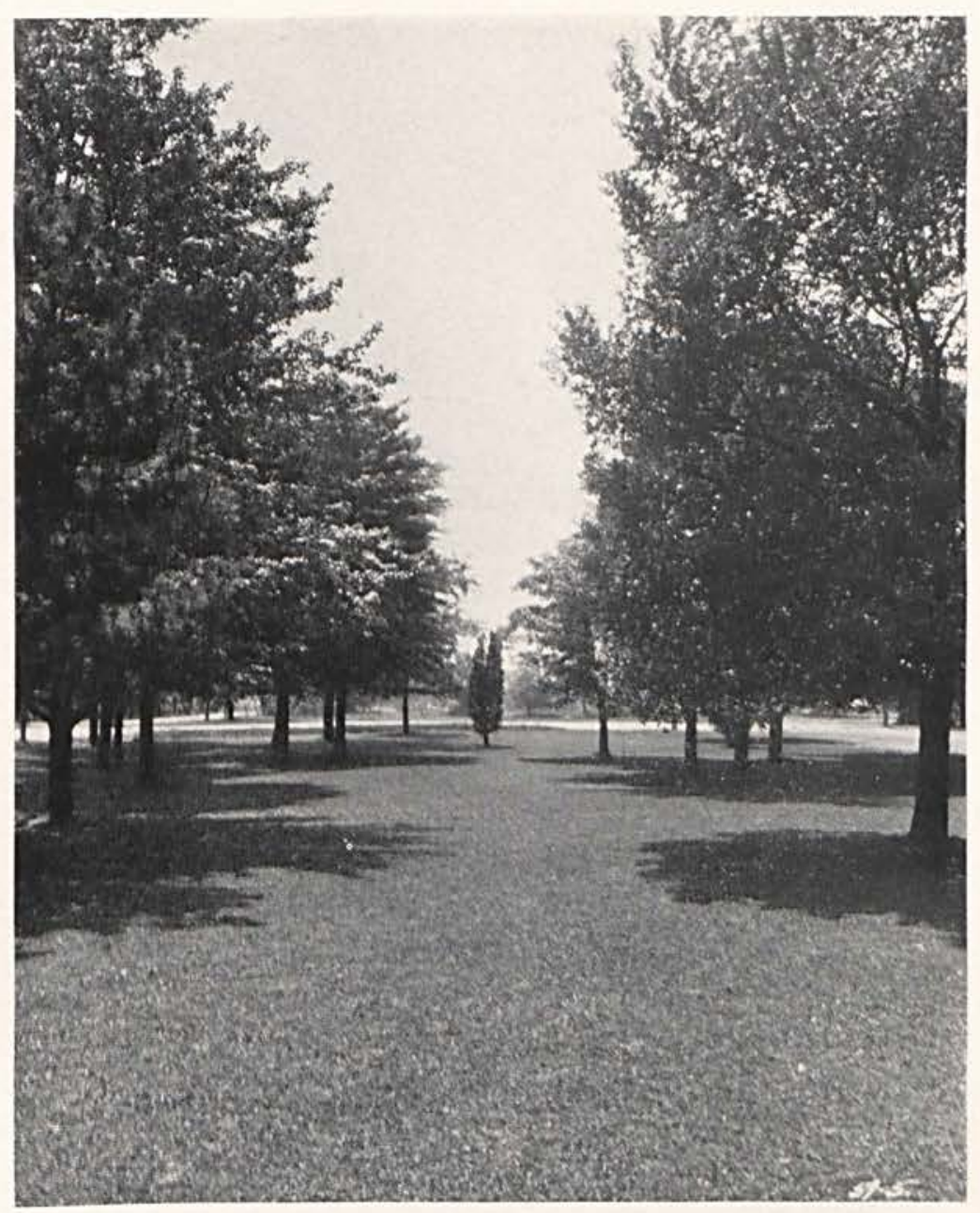

Whenever the moon and stars are set

Whenever the wind is high

It is things such as these

That make it hard to say good-bye.

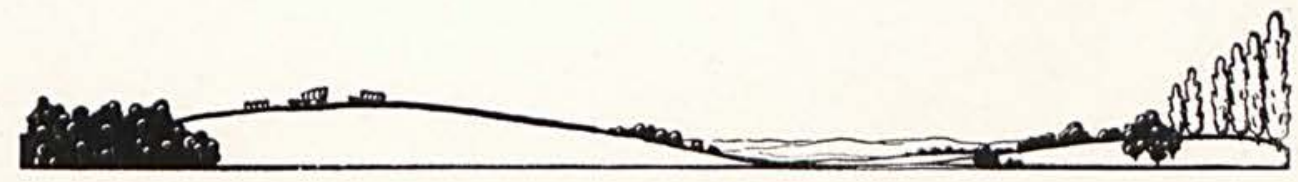


C E D R U S

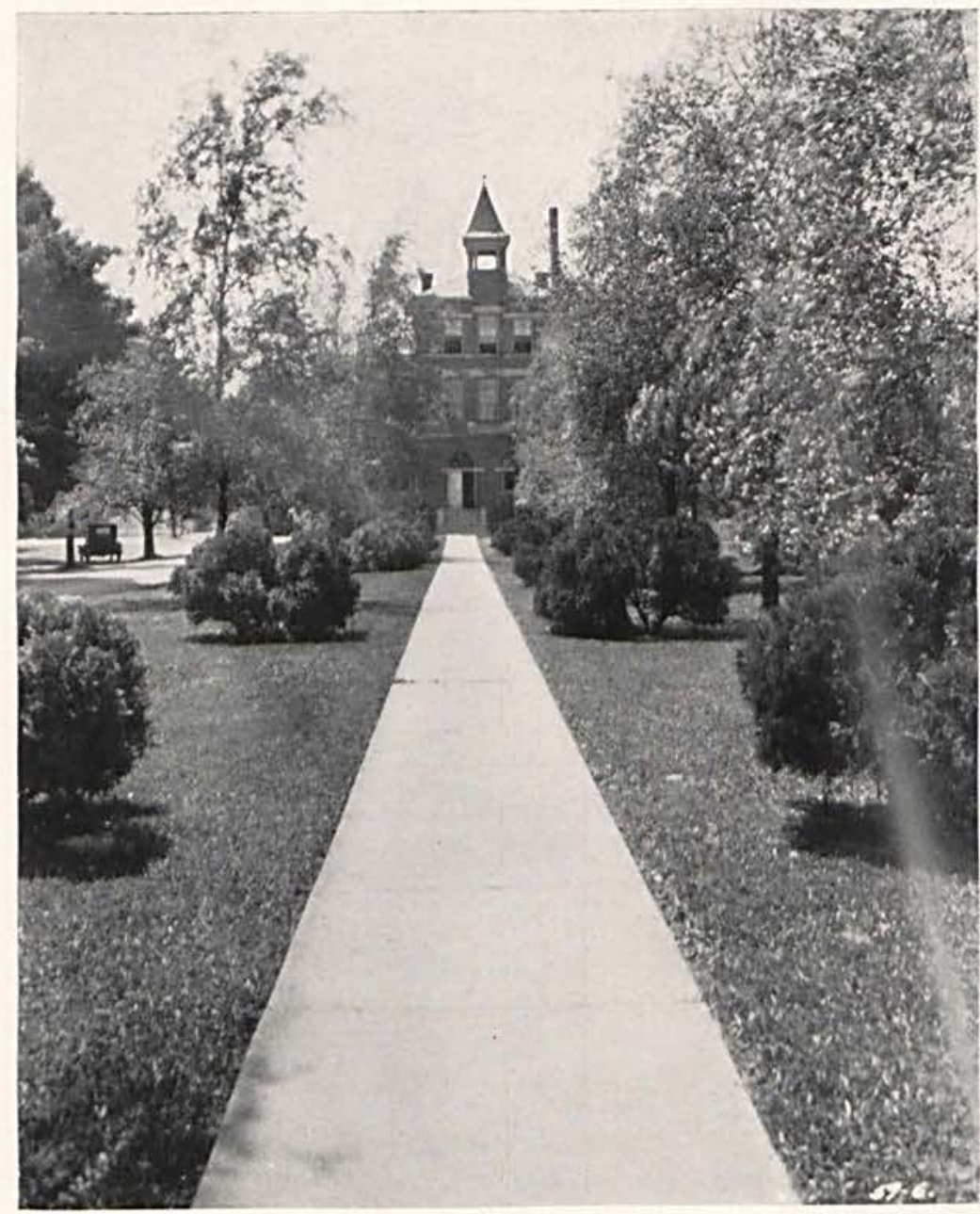

COLLEGE HALL

Lord God of Hosts be with us yet, Lest we forget, lest we forget.

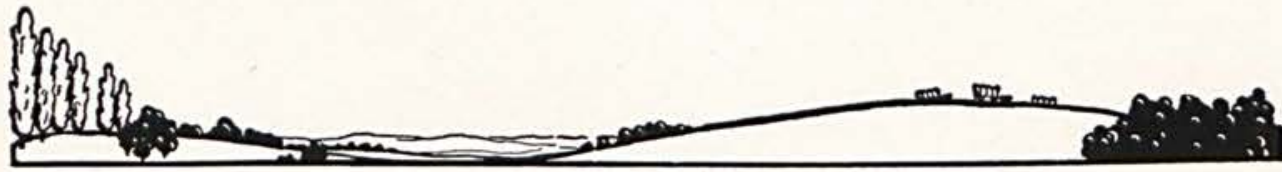




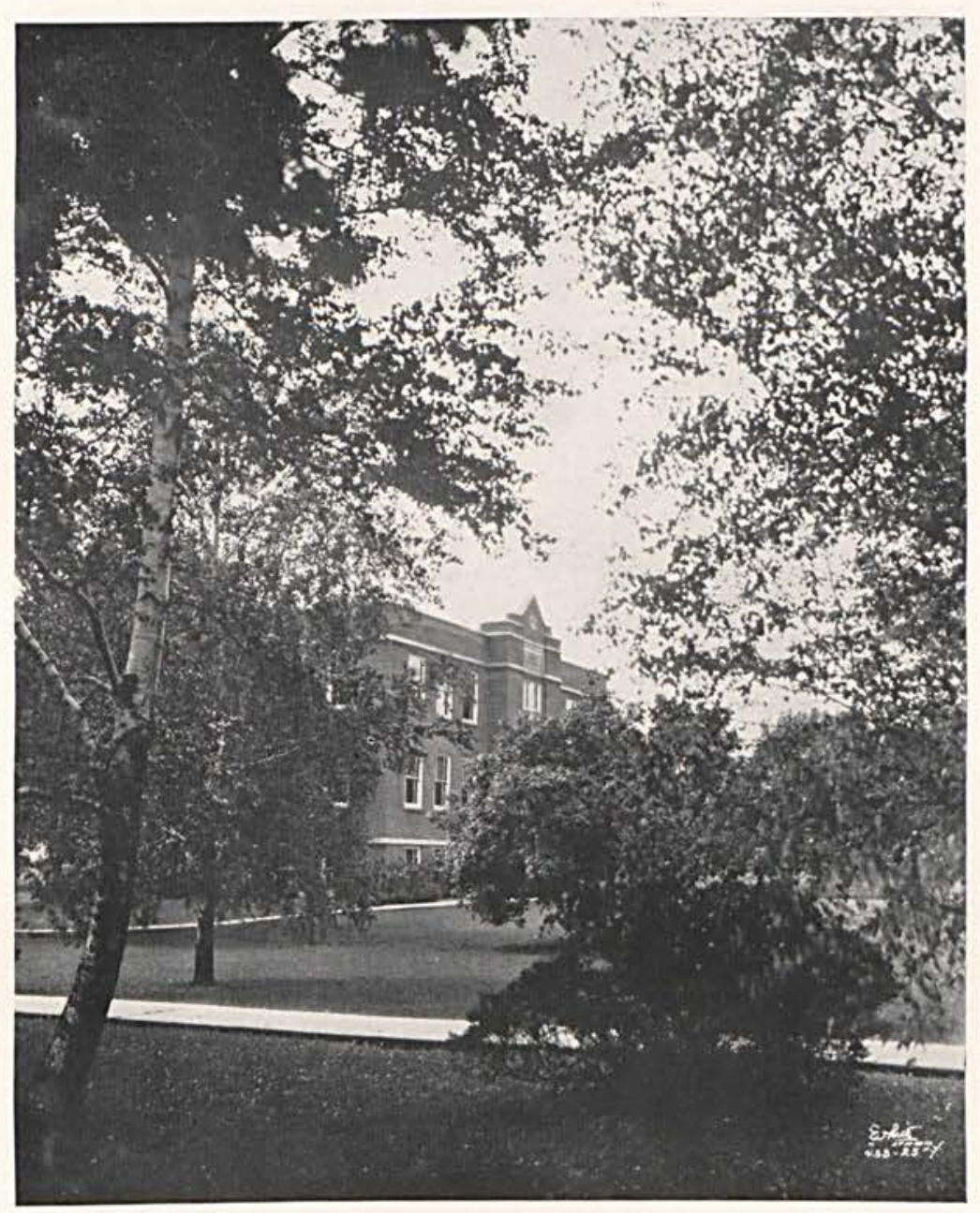

SCIENCE HALL

We lose sight of the grind spent here

When our mind lifts us up to memories dear.

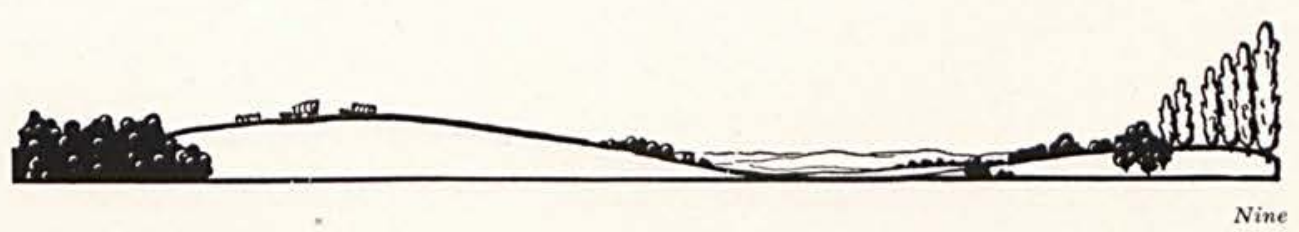




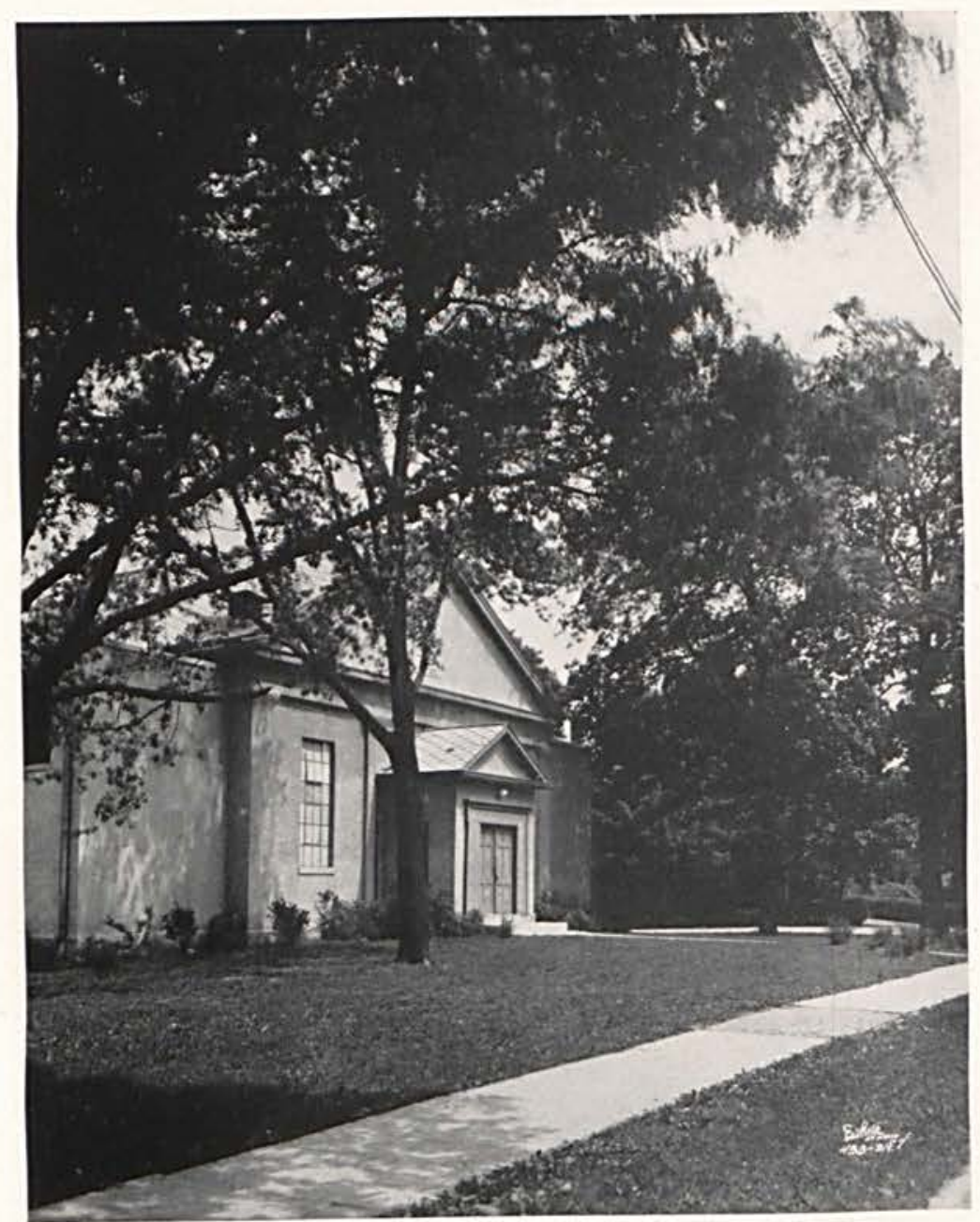

$$
\text { GYMNASIUM }
$$

Building our bodies toward supremacy

Teaching us the ideals of sportsmanship

Giving us a better understanding of our fellow students 


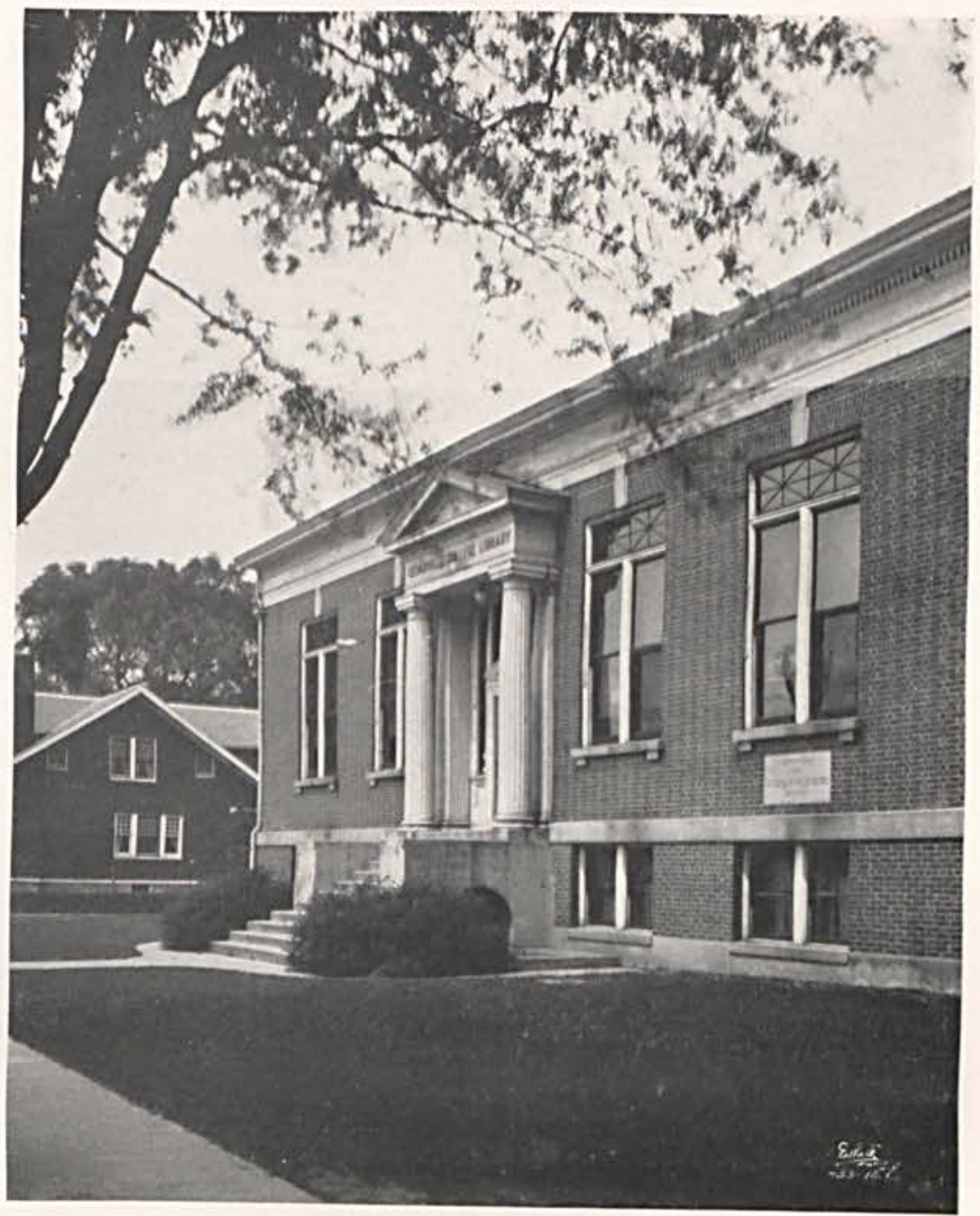

LIBRARY

If I might control the literature of the house-

hold, I would guarantee the well-being of church and state.

-Bacon

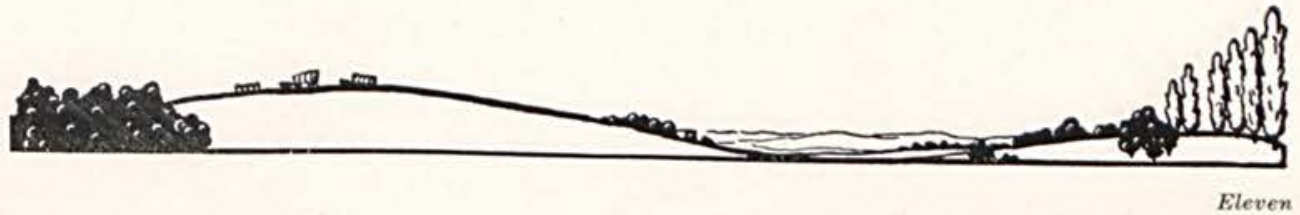




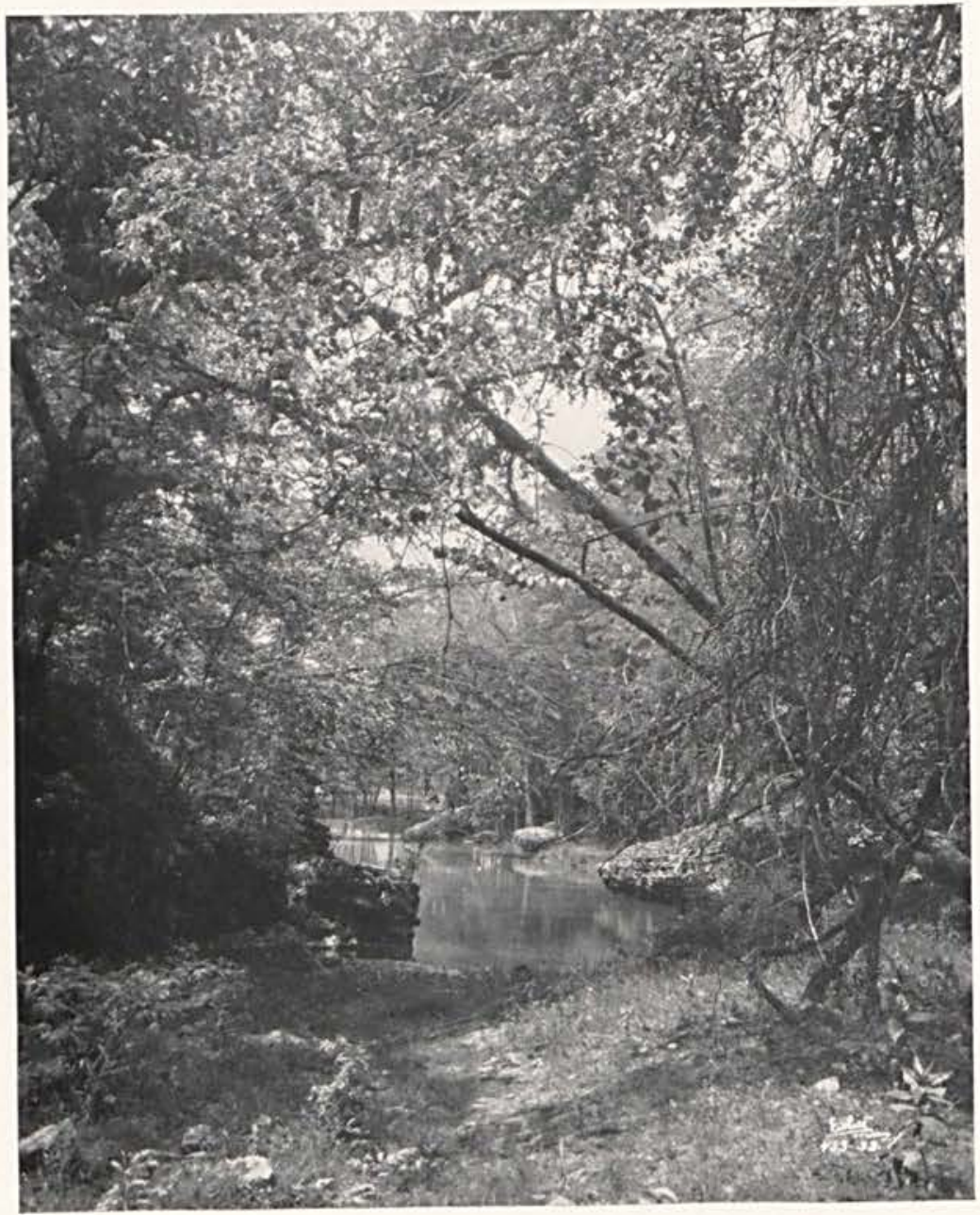

"Nature in all its splendor

Doth blend water, rock and shrubbery

Giving us heart-aching memories."

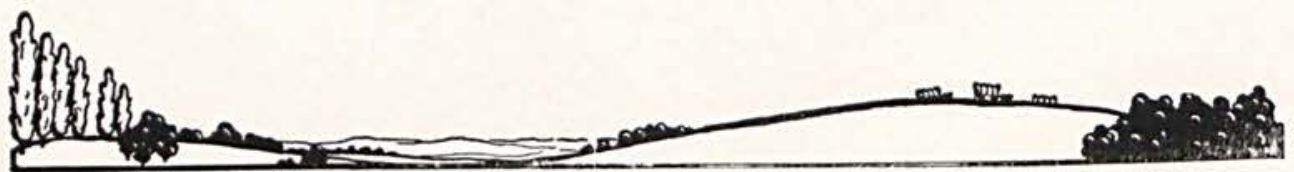




\section{Faculty}

Our faculty; not many have we

But what is lacking in number is made up in quality

They some times clamp down their iron hand

But we must remember, it is hard for students to understand.

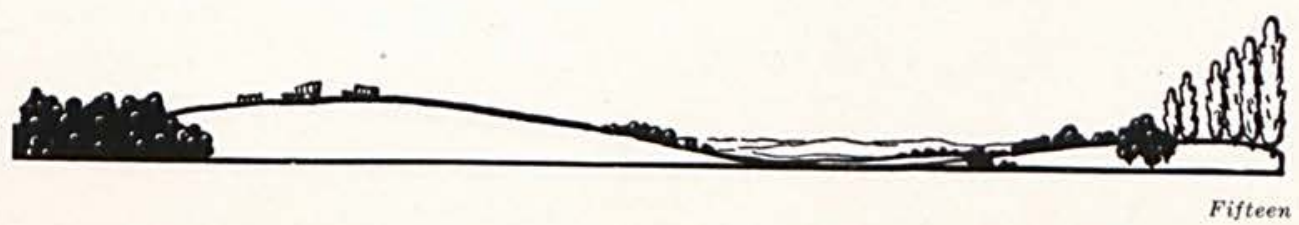


Out of the night that covers me

Black as the pit, from pole to pole, I thank whatever gods may be

For my unconquerable soul.

In the fell clutch of circumstance, I have not winced nor cried aloud. Under the bludgeonings of chance My head is bloody but unbowed.

Beyond this place of wrath and tears

Looms but horror of the shade

And yet the menace of the years,

Finds and shall find me unafraid.

It matters not how straight the gate,

How charged with punishment the scroll.

I am master of my fate,

I am captain of my soul.

—William E. Henley.

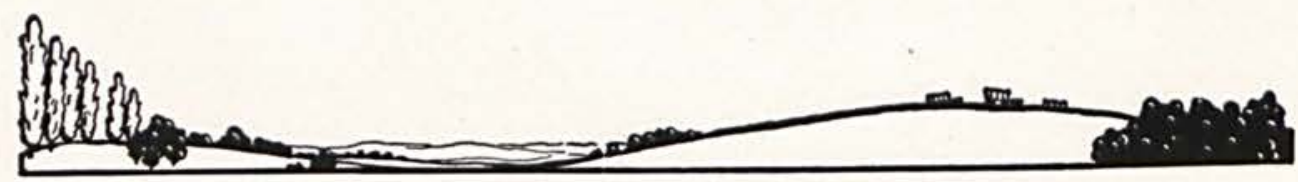




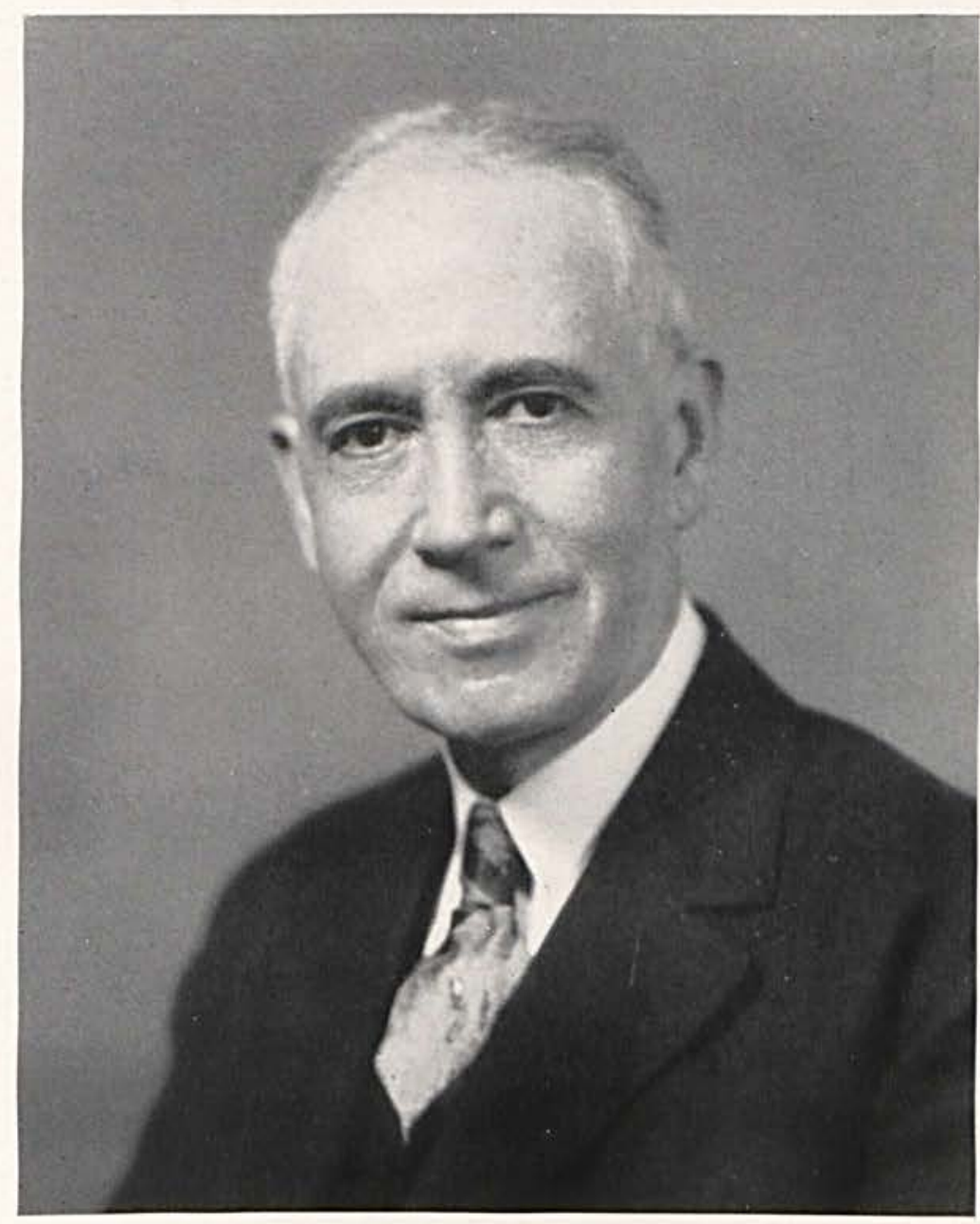

WILBERT RENWICH McCHESNEY, Ph.D., D.D.

President of Cedarville College

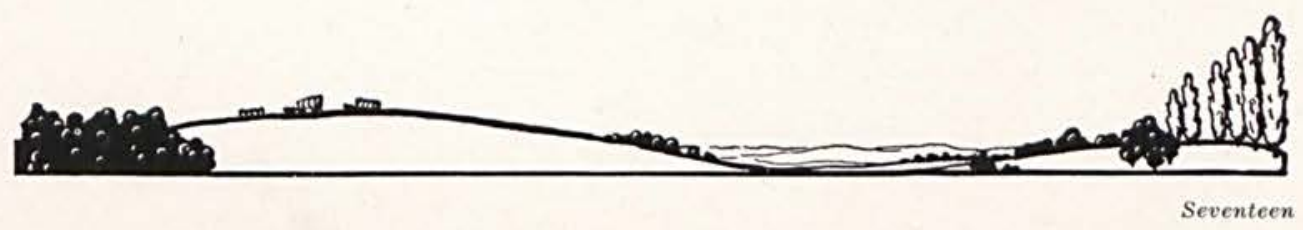




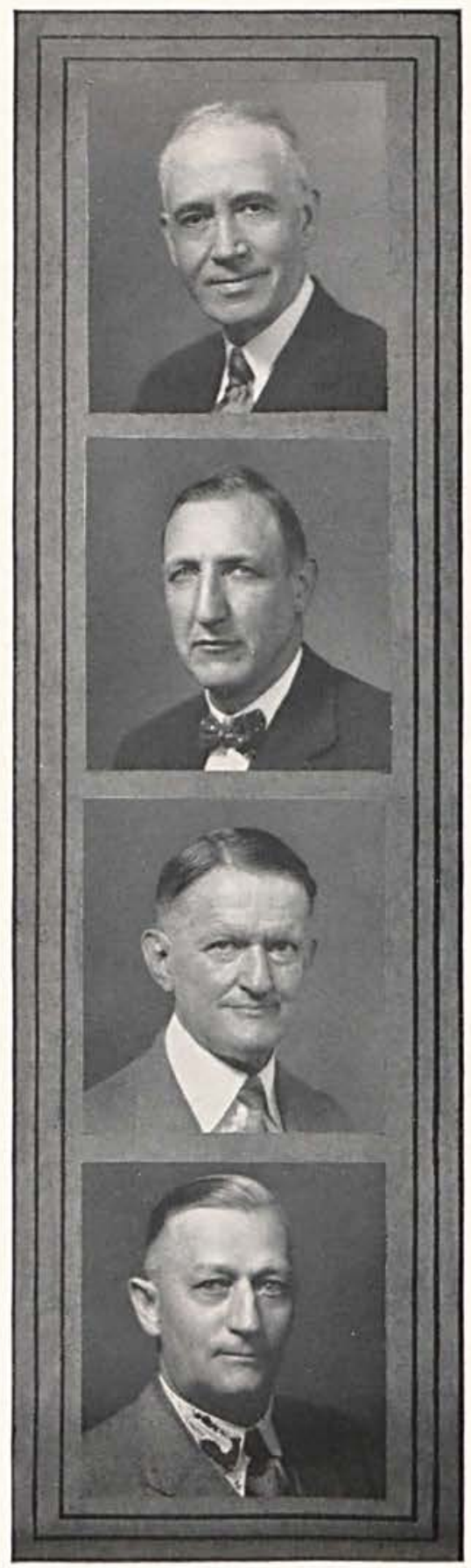

W. R. MCCinesNey

\section{President}

Peter Gibson Professor of Philosophy and Greek

A.B., Franklin College

A.M., Franklin College

Ph.D., Franklin College

D.D., Tarkio College

Frank A. Jurkat

Treasurer

Professor of languages and history

A.B., Franklin College

A.M., Franklin College

LL.D., Franklin College

A.M., Wittenberg

\section{J. A. Dickinson}

Vice-President

A.B., Wooster College

A.M., Wooster College

C. W. Steele

$$
\text { Dean of Men }
$$

Professor of Social Sciences and Bib'c

A.B., Indiana State Normal

Chicago University

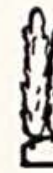

Eighteen 


\section{The Faculty}

$\mathrm{W}$

HAT we are we owe, in a large part, to our faithful and understanding faculty. Likening our school to a large family our faculty may be compared to parents, teaching, guiding, and keeping a kind and faithful arm around us. We wish to take this place to say what is in our hearts about our beloved faculty and to thank them for all they have made us.

Dr. McChesney, president of our college, has been the untiring father of Cedarville College since 1894. He has created in the hearts of hundreds of Cedarville College students the ideals of a loving kindness, wisdom, and a creative nature.

Dr. Jurkat, the treasurer of our little family, has been another one of our goals toward which to aim. As professor of history and German we have learned to love and reverence his ability and knowledge.

Dean Steele has been our adviser for two of the five years he has been with us. Every year has brought to us a warmer place in our hearts for him. An understanding nature and a smile for everyone. Professor of Bible and Sociology.

Dean Angevine, professor of English and Latin, has been our mother for two years and has guided us over many rough spots. We wish to extend to her all of the good wishes of the Student body.

Professor Hostetler, a man of extensive and unlimited ability. A director in the Educational Department and a man whose influence is state wide.

Professor Kuehrmann has built up the Science Department greatly. He is head of the Department of Science and a capable, likeable man.

Professor Davis, head of the Department of Mathematics, has added much to not only this department but to the welfare and work of the entire College.

Miss Berkley, head of the Department of Music, is to be greatly commended for her untiring efforts and her progress with this department. Her perseverance and ability has made our music department a leader among many of the larger colleges.

Mrs. Corry, assistant in the Department of Music, is also an able and energetic music instructor as well as being an active member of those who influence the community musically.

Coach Borst, Spanish instructor and Coach of our College, should be very highly commended upon his achievements in sports in the past years. He has done much to further the progress of Cedarville College and also to elevate the standards of Athletics in Cedarville College. He has spread Cedarville College's name through many of the large schools of Ohio and he has given us a high type of sportsmanship for an aim.

Miss Wolfe, who is a new member of our happy family, has gained the respect

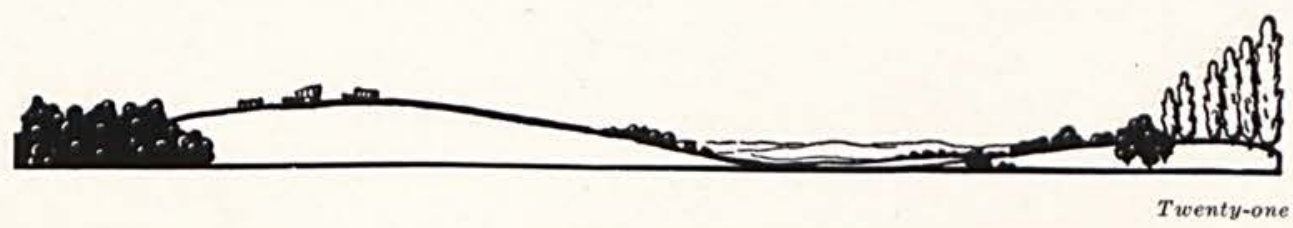




\section{E D R U S}

and love of the student body in the short time she has been with us. She is quiet and reserved, but let us not forget, "still water runs deep."

And now let us look at our faculty as a whole. We ask you confidentially: have you ever seen any other faculty which have the quality and class that ours has. May God always provide for Cedarville College, the quality of faculty members which have been provided in the past five years.

We express our gratitude to you faculty. We love you, every one of you and we wish you luck.
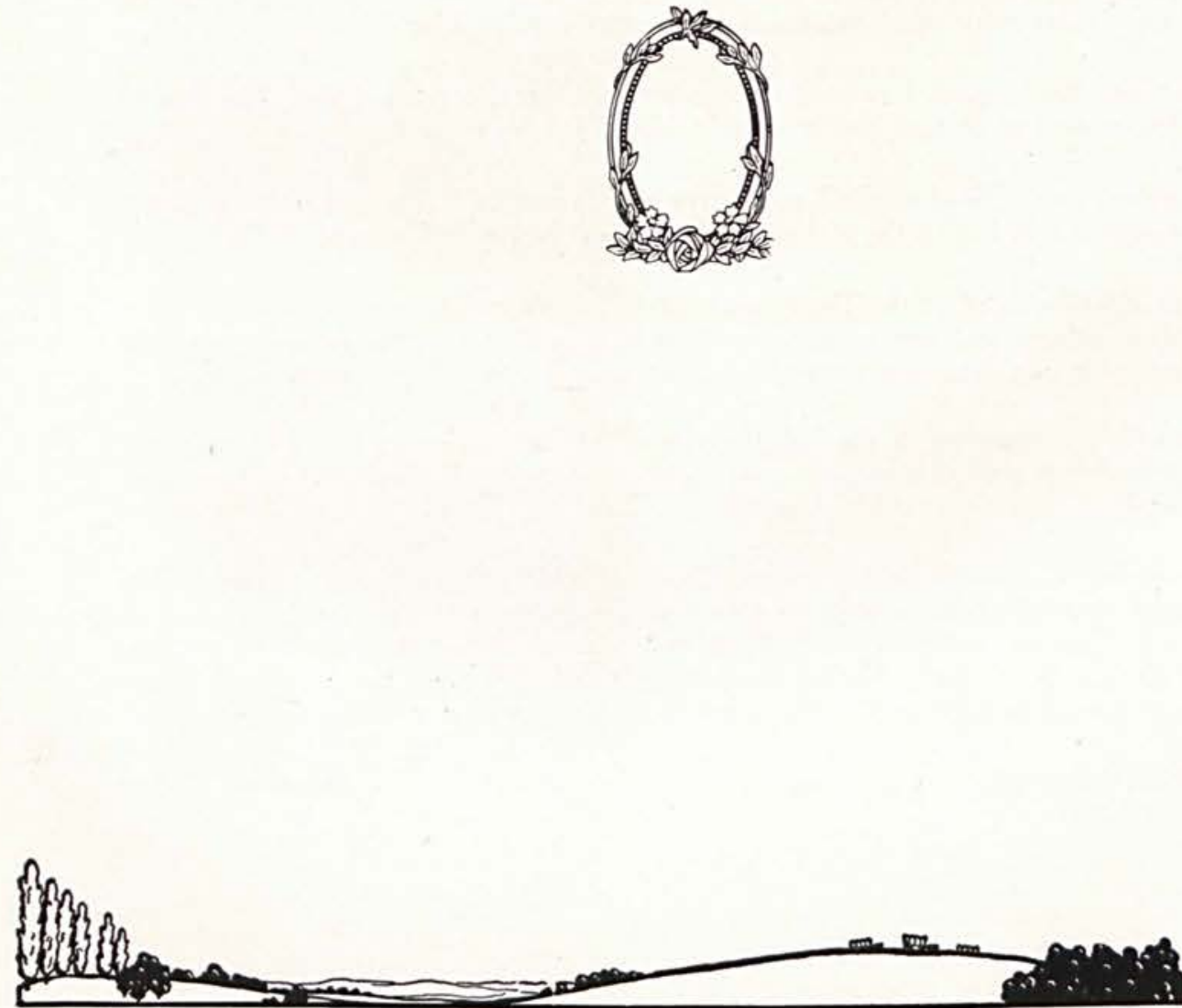


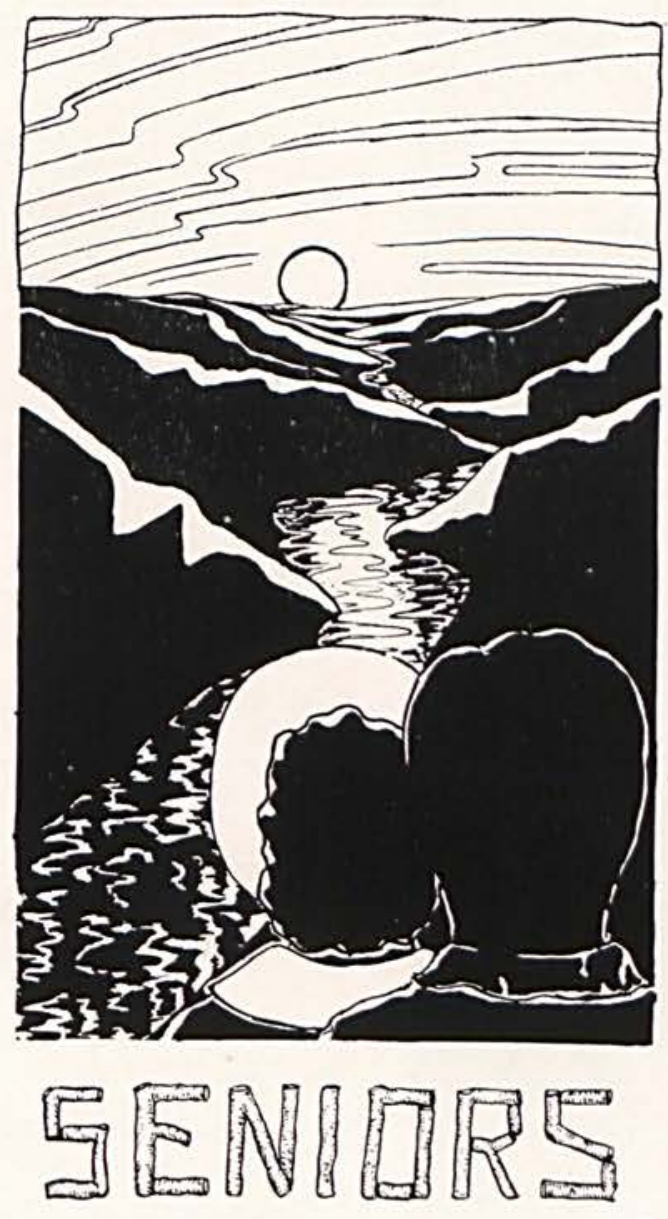





\section{ALFRED TOWNSLEY}

A. B. in Education

Cedarville, Ohis

\author{
Cedarville High School
}

"He gave to misery all he had, a tear.

He gained from heaven ('twas all he wished) a friend."

Y. M. C. A. 1, 2; Football 1, 2, 3, 4; Baseball 2, 3, 4; Basketball 3, 4; Class Officer 3; Junior Class Play 3; Club Steward 4; Address Junior-Senior Banquet 3.

\section{EDITH ELIZABETH FOSTER}

A. B.

Hamilton, Ohio Hamilton High School

" $A$ whole I planned,

Youth shows but half; trust God: see all, nor be afraid!

Western College for Women 1, 2, 3; Y. W. C. A. 4; Philosophic Literary Society 4; Mock Wedding Party 4; Bible Reading Contest 4; Social Committee 4 .

\section{J. ROBERT COLLINS}

A. B. in Education

Cedarville, Ohio

"Think then you are Today what Yesterday

You were-Tomorrow you shall not be less."

Football 2, 4; Basketball 3, 4; Tennis 4; Social Committee 2, 3, 4; Banquet Committee 3; Junior Play 3; Cedrus Staff 4; Cedrus Play 4; Philosophic Literary Society 2, 3, 4; Y. M. C. A. 1, 2, 3, 4; Minstrel 1, 3; Class Officer 4; Student Body President 4; Assistant in Chemical Laboratory 4.
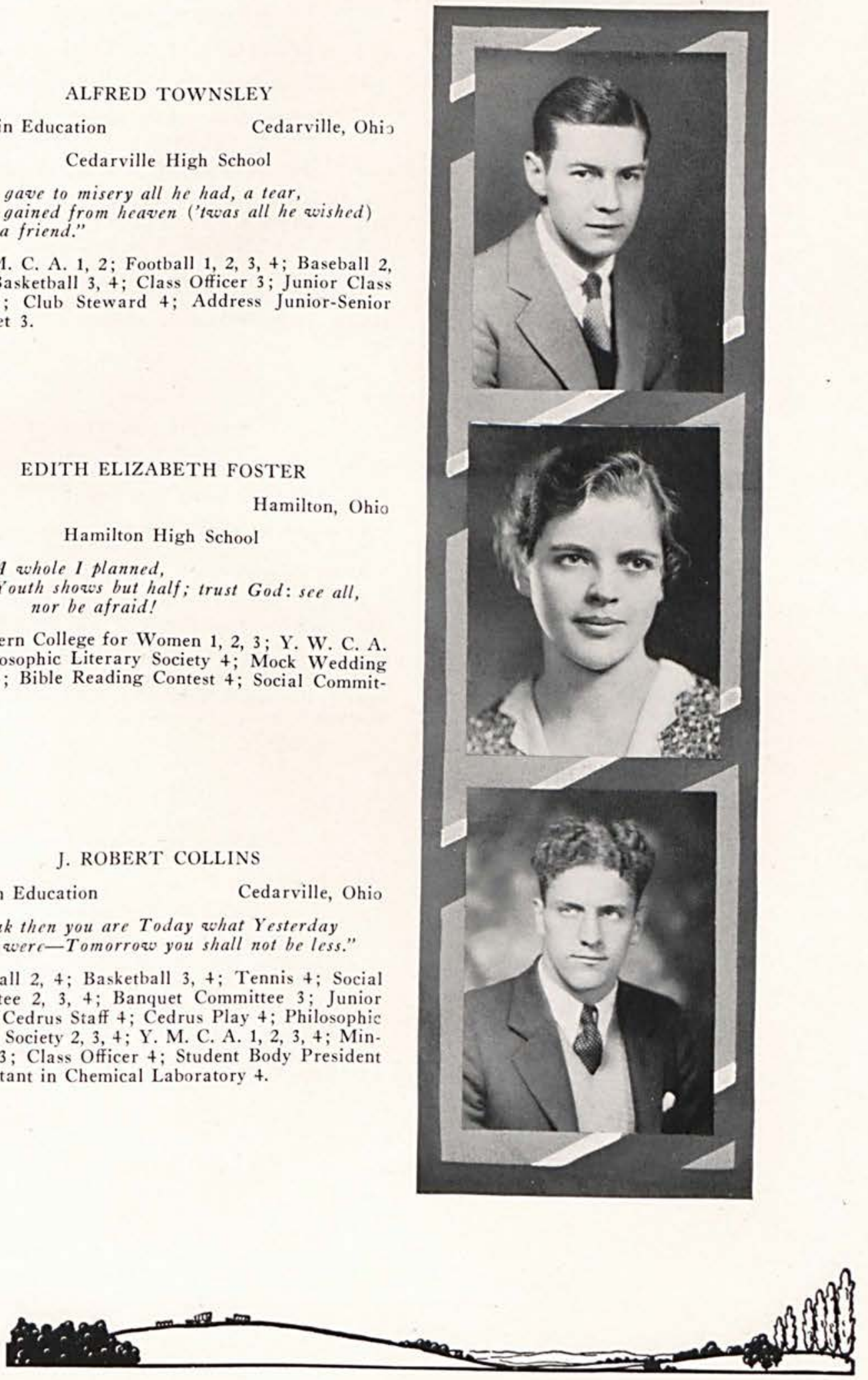

Twenty-sever 


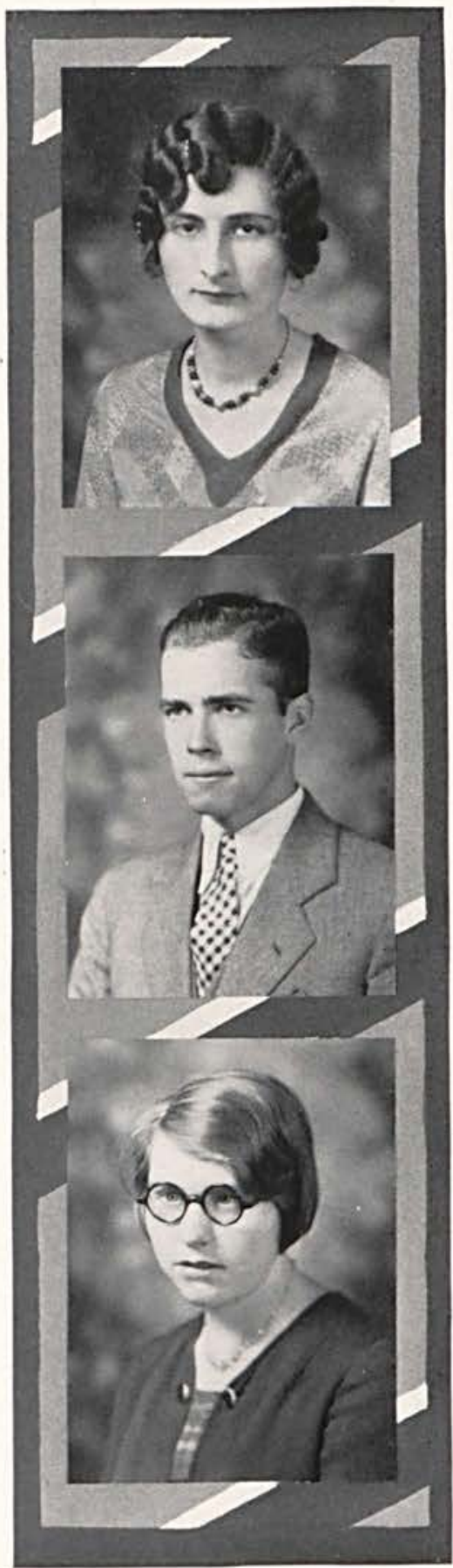

MILDRED M. CARLE

A. B. in Education

Xenia, Ohio

Caesarcreek High School

"My mind to me a kingdom is,

Such present joys therein I find

That it excells all other bliss

That carth affords or grows by kind;"

Y. W. C. A. 1, 2, 3, 4; Secretary and Treasurer 4; Crown Club 3; Giris Student Council 3; Basketball 1, 2, 3, 4; Manager 3, 4; Philosophic Literary Society 1, 2, 3, 4; College Club 1, 2, 3; Junior Ciass Play 4; Class Secretary 3; Cedrus Staff Play 2; Attendant to May Queen 4; Mock Wedding 3; Groom 4; Bible Reading Contest 4; Class History 3 .

\section{JOSEPH FOSTER}

A. B.

Hamilton, Ohio

Hamilton High School

"No man heath walked about our roads with step So active, so inquiring eye, or tongue

So varied in discourse."

Class Secretary 2; Chairman Play Committee 3; Philosophic Literary Society 2, 3, 4; Bible Reading Contest 4; Y. M. C. A. 2, 3, 4; Business Manager Junior Class Play 3; Assistant Business Manager Cedrus Play 4; Men's Glee Club 3; Baseball Manager 4; Basketball Manager 4; College Minstrel 3; Football 2, 3.

\section{BERNICE LEAH BRYANT}

A. B. in Education

Cedarville, Ohio

Cedarville High School

"True worth is in being, not seemingIn doing, each day that goes by,

Some little good-not in dreaming Of great things to do bye and bye."

Wittenberg Summer School 1, 2; Y. W. C. A. 1, 3, 4; Publicity Chairman 4; Mock Wedding 4; Glee Club 4; Bible Reading Contest 1, 3, 4.

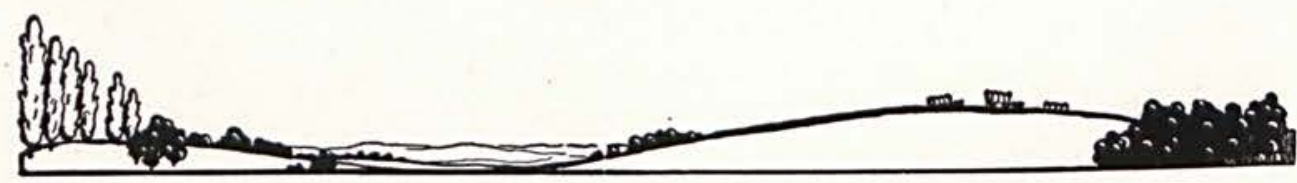




\section{E D R U S}

\section{HELEN K. POWERS}

A. B. in Education

Cedarville, Ohio

Selma High School

"Was it a vision, or a waking dream?

Fled is that music:-Do I wake or sleep?"

Graduate in Pianoforte 1; Graduate of C. C. Preparatory Department 2; Bible Reading Contest 2, 3, 4; Third Prize 3; Glee Club 2, 3, 4; Philosophic Literary Society 1, 2, 3; Y. W. C. A. 1, 2, 3, 4; Mock Wedding, Bride 4; Invitation Committee 4; Commencement Committee 3; Junior Class Plays 3,4 ; Class Historian 4 .

\section{WENDELL BOYER}

A. B. in Education

Goodhope, Ohio

Wayne High School

"So much one man can do

That does both act and know."

Y. M. C. A. 1, 2; Philosophic Literary Society 1 ; Cedrus Staff, Editor 4; Student Body 4; Glee Club 3; Minstrel 3; Football 3, 4; Basketball 2, 3, 4; Baseball 2, 3, 4 ; Class Play 3, 4 ; Cedrus Staff Play 4 ; Bible Reading Contest 3, 4 .

\section{CHRISTINE RIFE}

B. S. in Education

Cedarville, Ohio

Cedarville High School

"And still she slept an azure-lidded sleep, In blanched linen, smooth and lavendered."

Philadelphian Literary Society 1; Philosophic Literary Society 3, 4; Class Play 3; Play Committee 4; Y. W. C. A. 1, 2, 3, 4; Glee Club 2, 3.
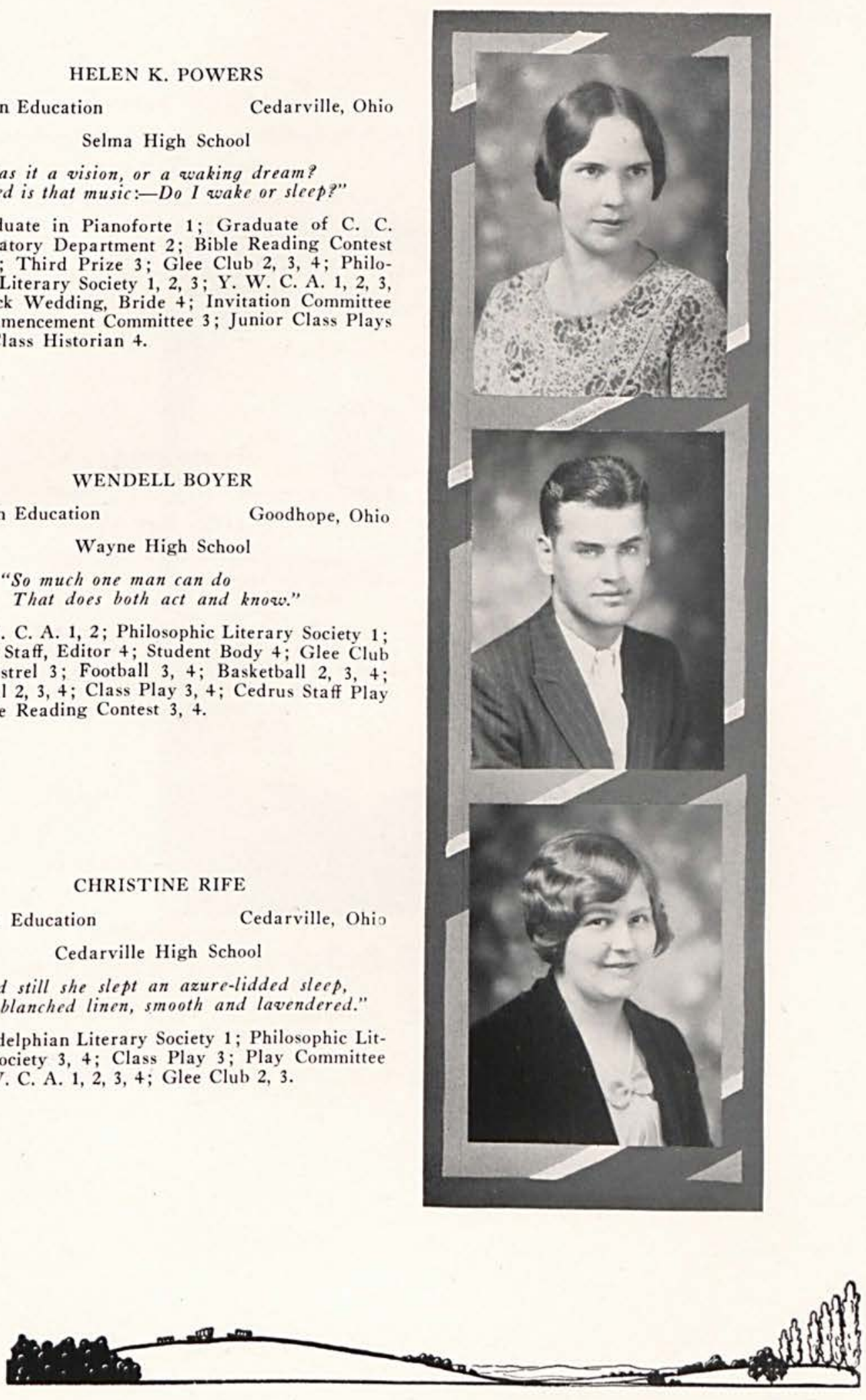


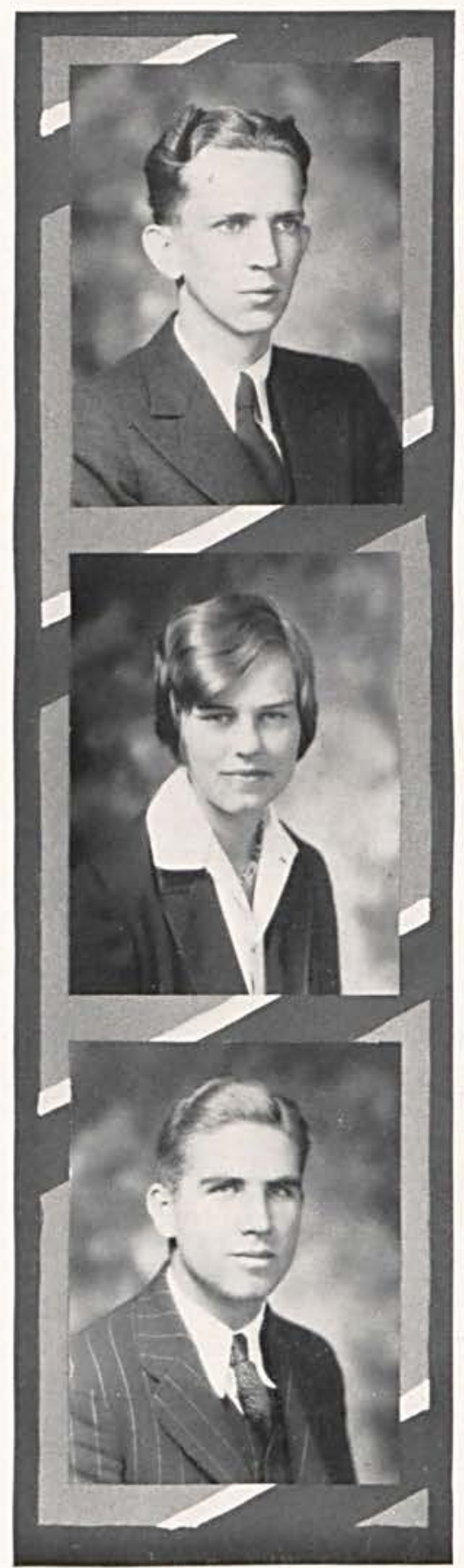

\section{J. VERNON HICKMAN}

A. B. in Education

Springfield, Ohio

Xenia High School

"True wit is nature to advantage dressed,

What oft was thought, but ne'er so well expressed."

Y. M. C. A. 1, 2, 3, 4; President 4; Class Treasurer 4; Glee Club 3; College Band 3; Class Play 3, 4 ; Bible Reading Contest 3; Cedrus Staff 4; Toastmaster Junior-Senior Banquet 3.

\section{WILMA CURRY}

A. B. in Education

Wellsville, Ohio

Wellsville High School

"Our sincerest laughter with some pain is fraught, Our squeetest songs are those that tell of saddest thought."

Y. W. C. A. 1, 2, 3, 4; Cheerleader 1, 2, 3; Philosophic Literary Society 1, 2, 3, 4; Cedar Day 2, 3, 4; May Queen Attendant 3; Banquet Committee 3 ; Cedrus Play 2; Cedrus Staff 2, 3; Glee Club 2, 3, 4 ; Junior Play Committee 3 ; Senior Play 4.

\section{BRENTON R. TURNER}

A. B. in Education Quincy, Mass.

Quincy High School

"Calm in his voice, calm within his eye-

Not always sign with him of calmest mood."

President of Class 1; Y. M. C. A. 3; Cedrus Play 1, 2; Pilosophic Literary Society 3; College Quartette 4; Cedrus Staff 2, 3; Baseball 1, 2, 3, 4; Y. M. Cabinet 2, 3,4; College Minstrel 1, 3; President of Tennis Club 4.
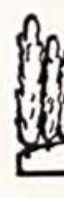


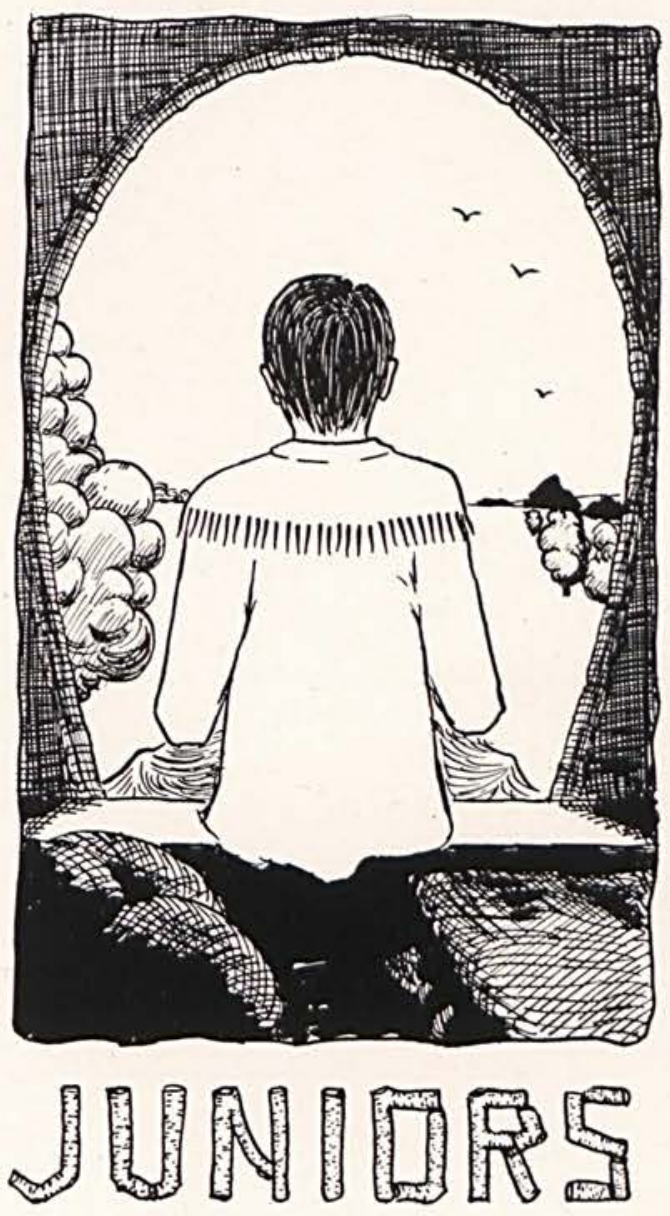




\section{Juniors}

The Juniors, witty and with their cultivated sense;

Made so by their three years of experience,

Do not know how little they know,

But they will find;

And if you don't believe us ask the Seniors, kind;

You shall reap just what you sow.

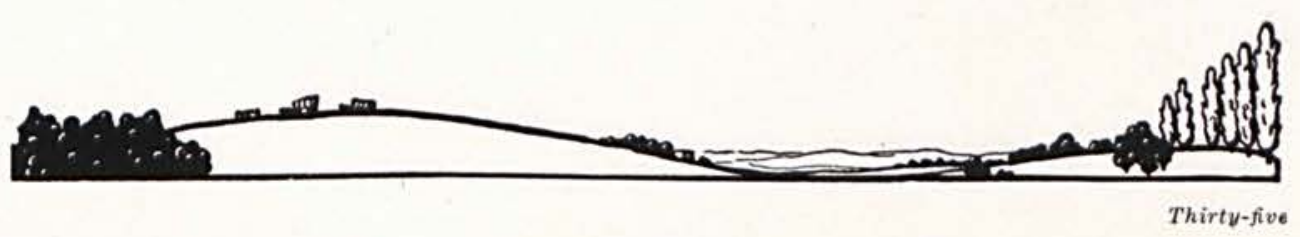




\section{E D R U S}
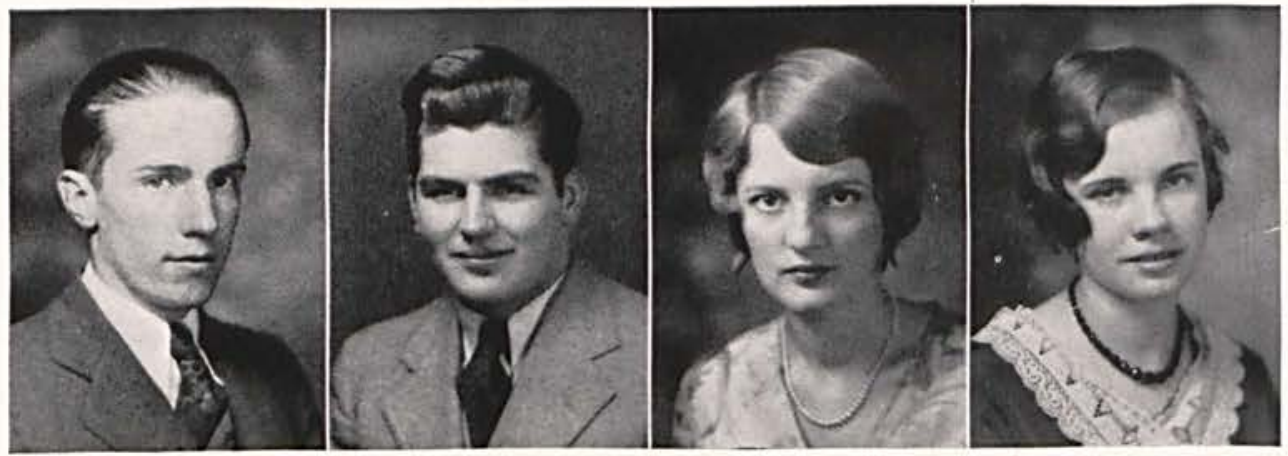

\section{Junior Class}

Robert Wilson President

Edward Irons Vice President

Martha Waddle Secretary and Treasurer

Rachel Daulthet Business Manager

\section{JUNIOR CLASS HISTORY}

T seems altogether fitting that since we are nearing the sunset of our college days we should review some of the gallant deeds done by our members.

In the fall of 1928 we embarked upon our voyage. We were properly initiated by the upper-classmen, and thanks to them some of our boys received free haircuts. We had two delightful feeds with the remainder of the student body joining to make it a grand success. Most of these freshmen returned in 1929 and had a very prosperous year.

We try to neglect no field of endeavor. We have maintained our standing in the line of athletics. Some of the flashiest members of the squad were found from our ranks. The girls went out for basketball and glee club gained a name for themselves in both places. In classrooms, sports, literary activities, spreads, and various organizations you will find the necessary quota of Juniors. Every college needs a cheerleader and one of our rank naturally stepped into that position. Then we also shine in the classroom. In scholastic standing the Juniors hold their own.

This year we laid the foundation for a great class, and true to all plans, our class has made its appearance in every activity of the college. On the eighth of April we presented the play "Old Lady 31." Now we are planning to entertain the Seniors in a royal manner.

We have just one more year in which to gain greater fame. If our crew all pulls together there is no limit to the heights we can attain.

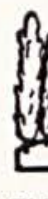

Thirty-gix 


\section{SARAH MARGARET CHANCE}

She's just a real pal and one who can be depended upon. Has a weakness for preachers' sons. There's more than paying the preacher!

\section{HENRY IDDINGS}

The college clown! From the top of his head up; he has all of us beaten in brains. Likes his teachers, but not his books.

\section{LENORA SKINNELL}

Lenora as charmed all of us more than once with her music and pleasing manner, but be careful Nancy, lullabies are different.

\section{DONALD ALLEN}

Chcppy doesn't let his eight o'clock classes interfere with his sleep. Was afraid of women for one evening but, no doubt, he made up for lost time.

\section{RACHEL DOUTHETT}

Few have such a genuine friendliness, made up of a winning smile, a rare sense of humor and a sincere interest in others.
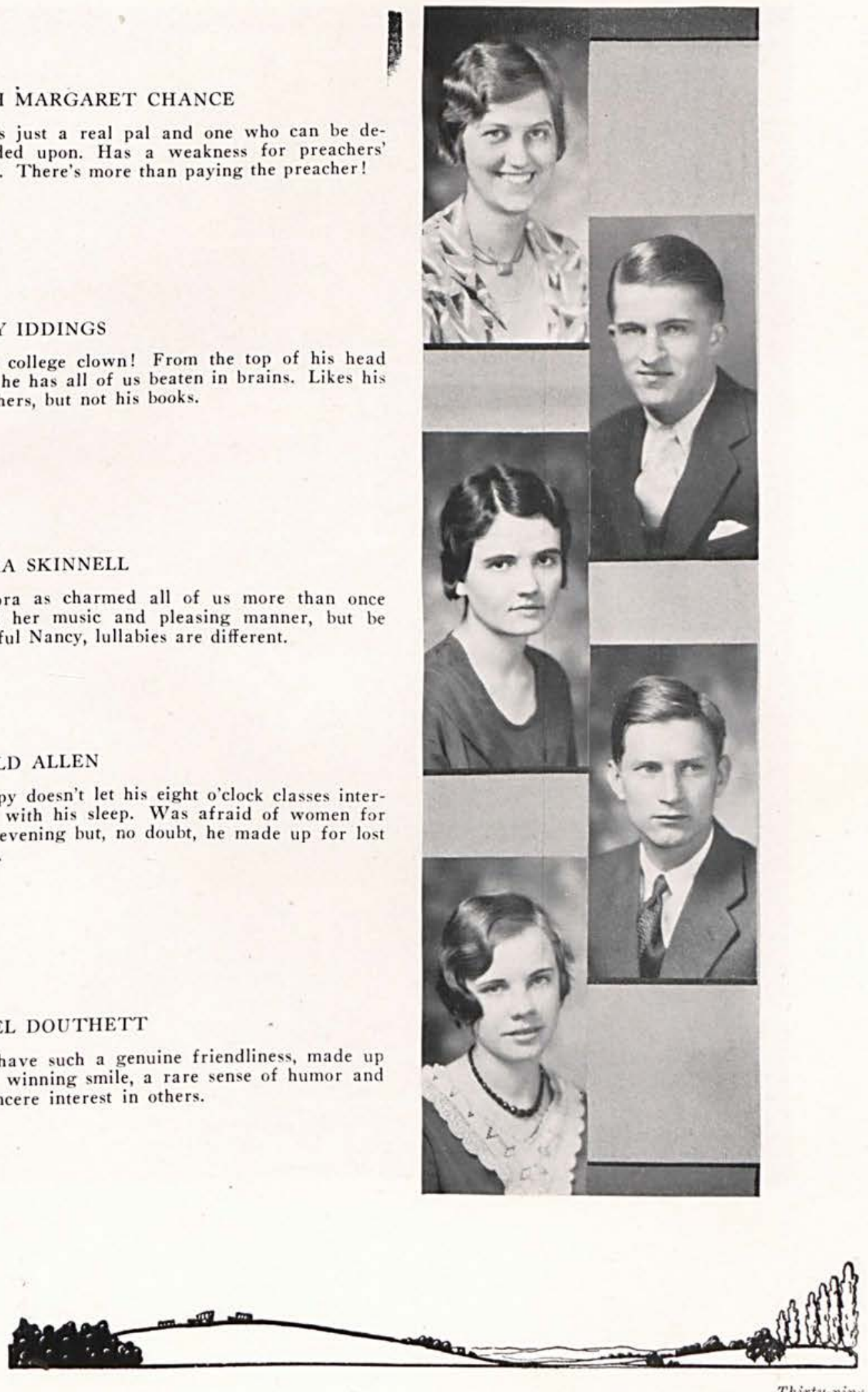

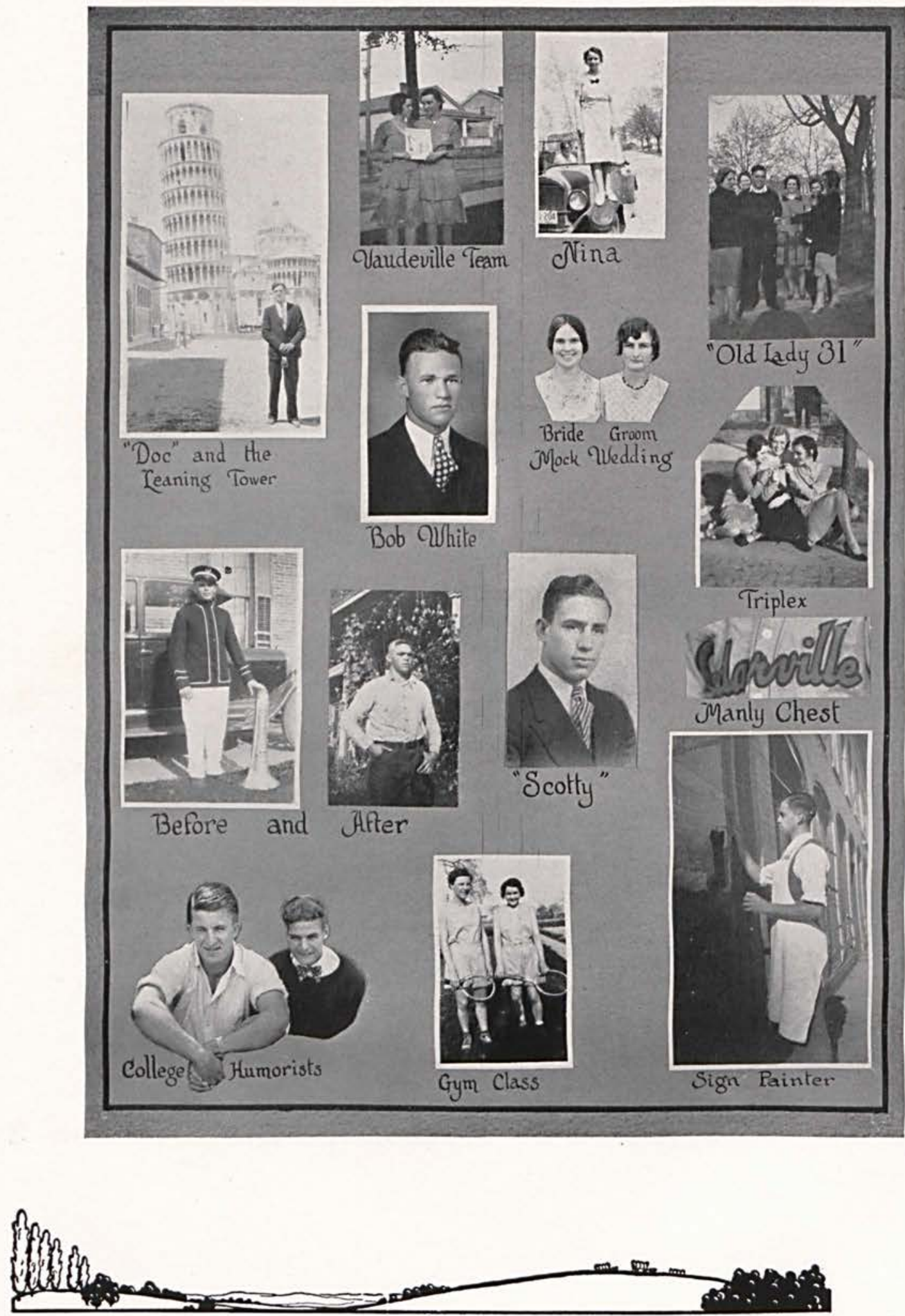


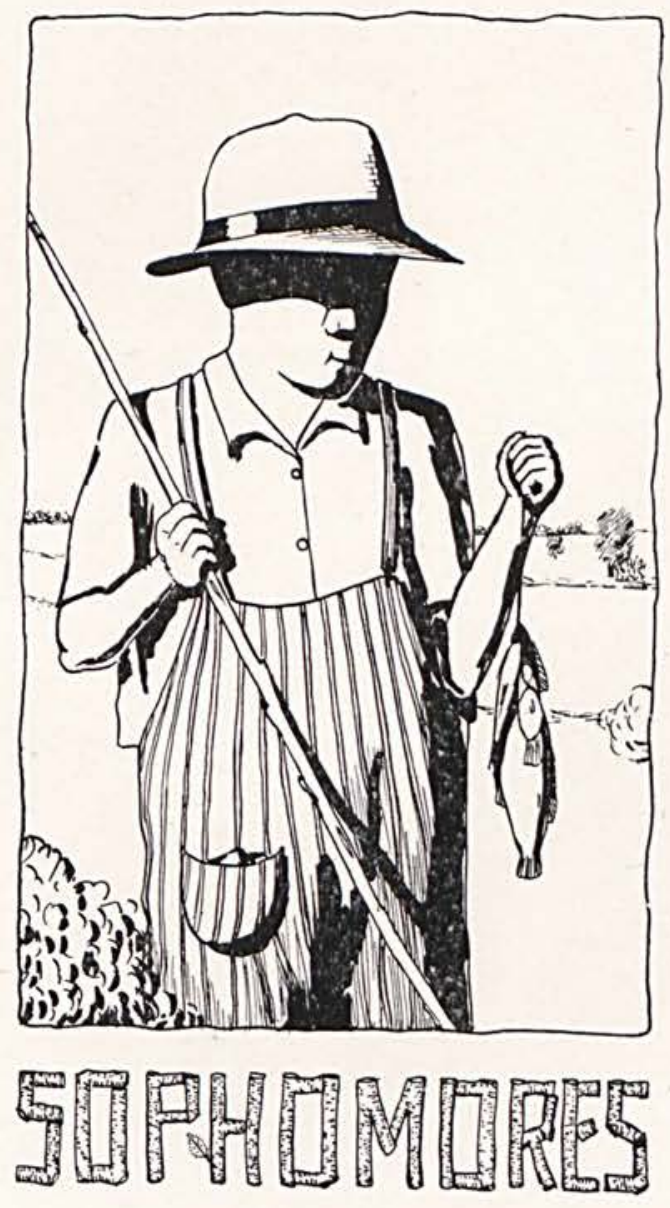


C E D R U S

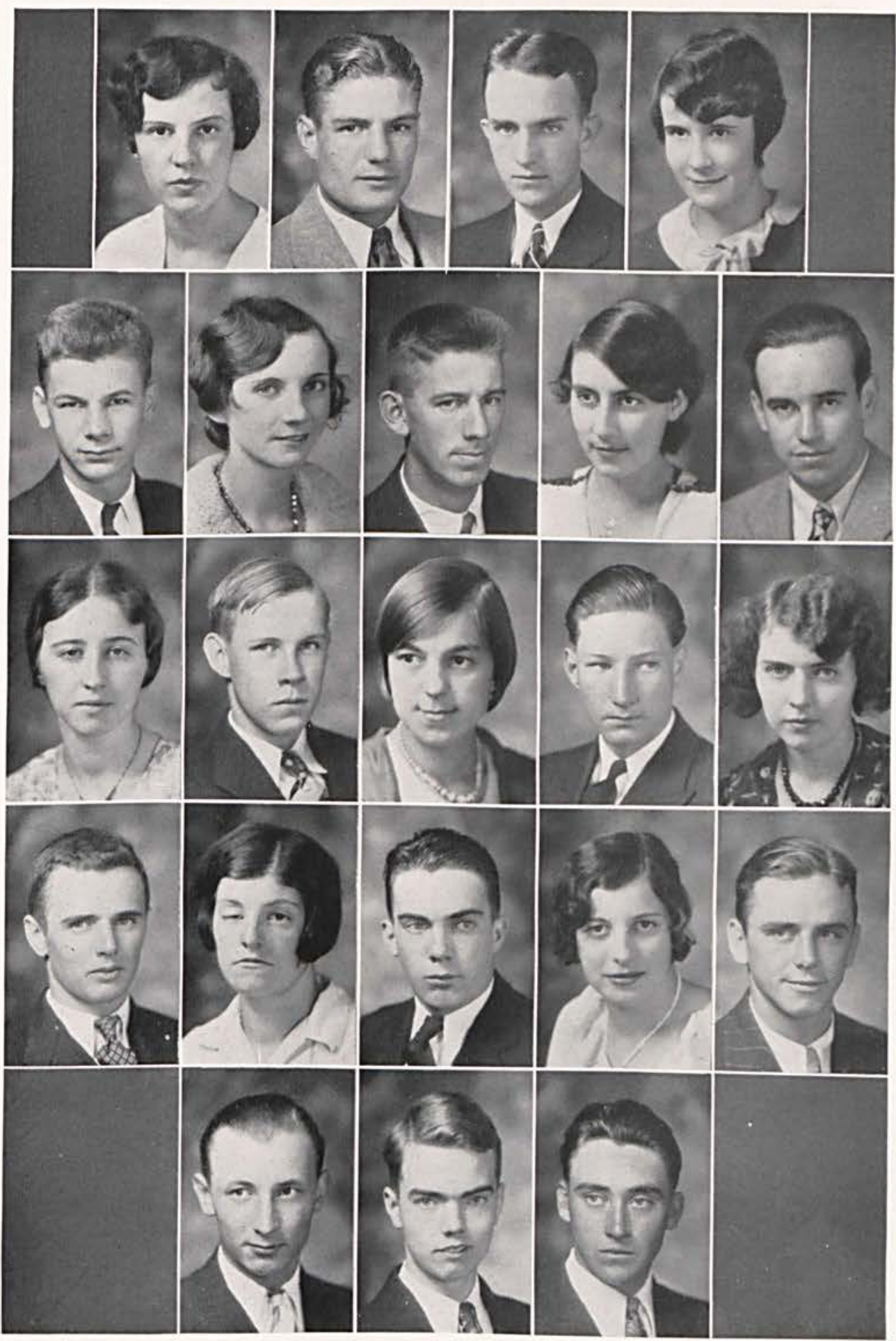

Bernice Elias, Winthrop Ballard, Lewis McLaughlin, Dorothy Swaly, Harold Baker, Lucille Stroup, Preston Garlow, Ruth Sprinkle, Jack Osborn, Viola Harbull, Robert Gichards, Marjory Cotton, Chas, Bost, Edith McDonald, Edwin Bull, Mary Andrus, Willis Spencer.

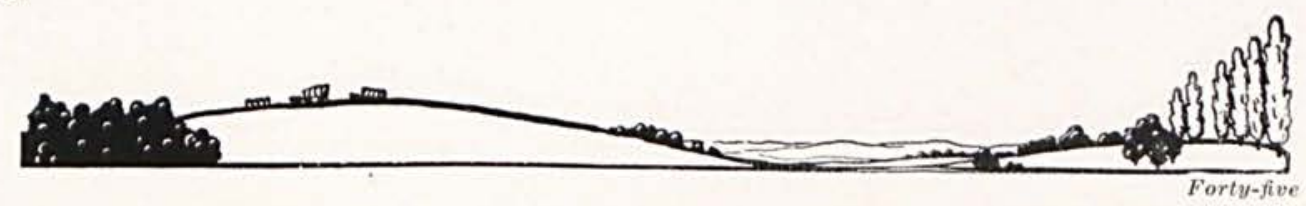


C E D R U S
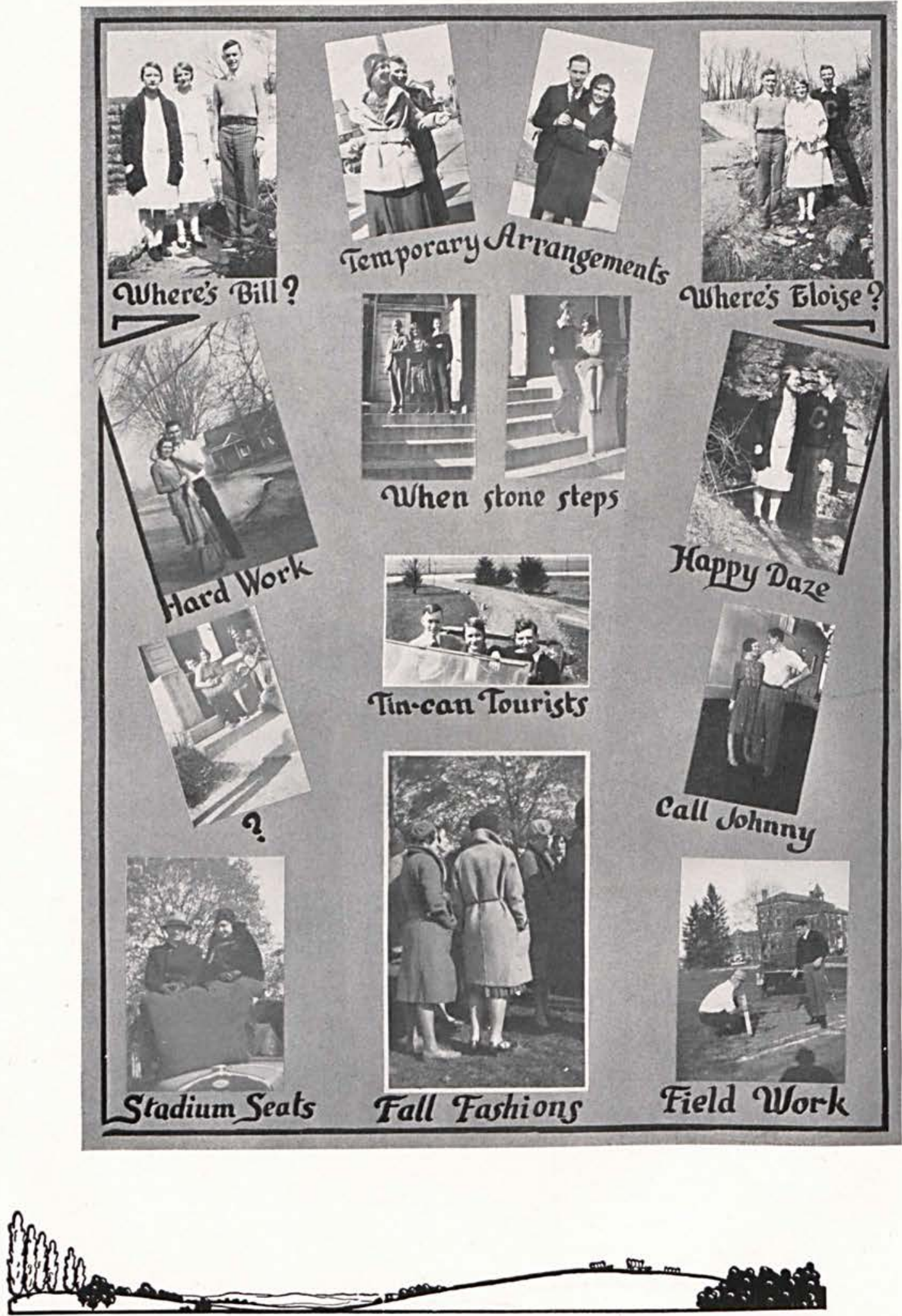


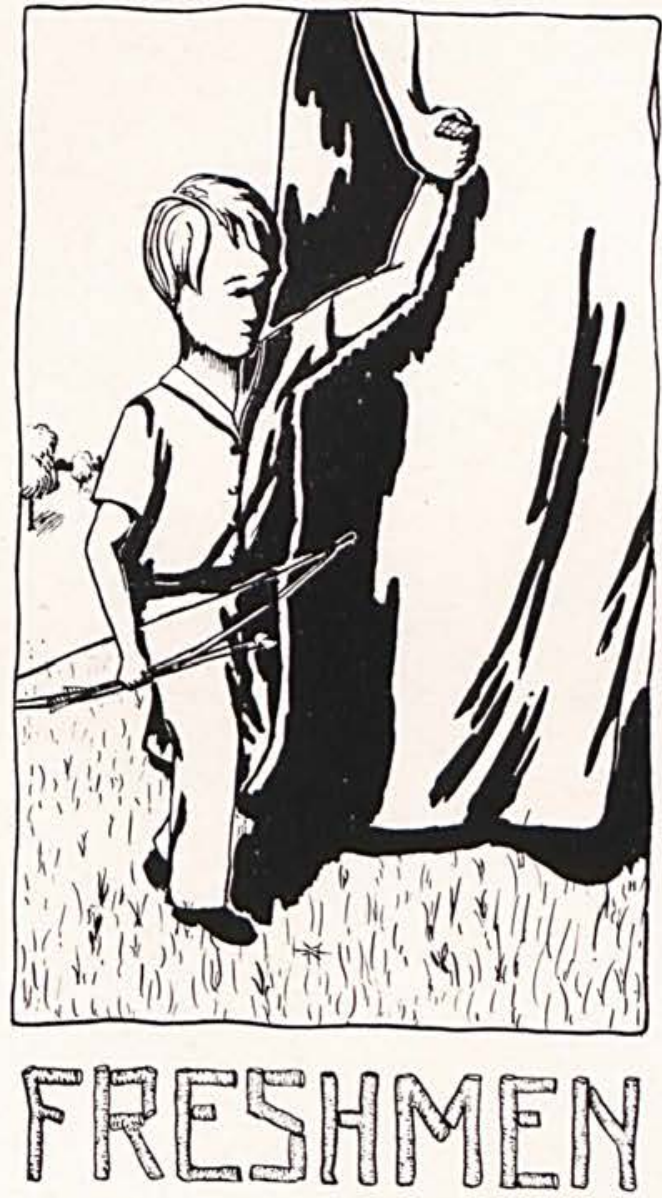





\section{Freshmen}

There are exceptions to all rules.

We grant that, do we not?

Sure we know Freshmen are supposed to be green,

And really are not meant to be seen.

Our Freshmen are true blue and white

But of course we must challenge them to fight.

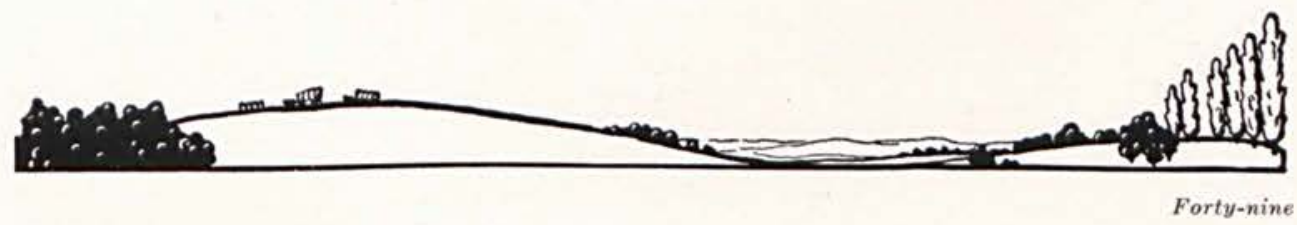




\section{Freshman Concord Hymn}

By these stately halls which make for education

Their flag to April's breeze unfurled;

Here once the Seniors tore up creation,

But here now Freshmen lie like contented kittens curled.

The Faculty long since in silence slept;

Alike the conqueror silent sleeps;

And in time these stately halls will sweep

The Freshmen down the stream.

Spirit, that made these Freshmen dare

To enter College and leave homes so free,

Bid time and nature gently spare

This honor we give to them and thee.

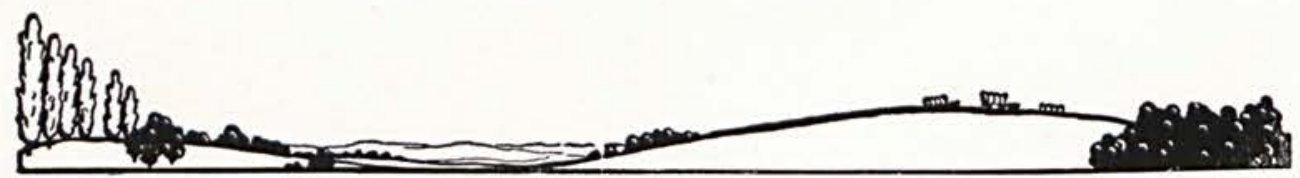





\section{E D R U S}

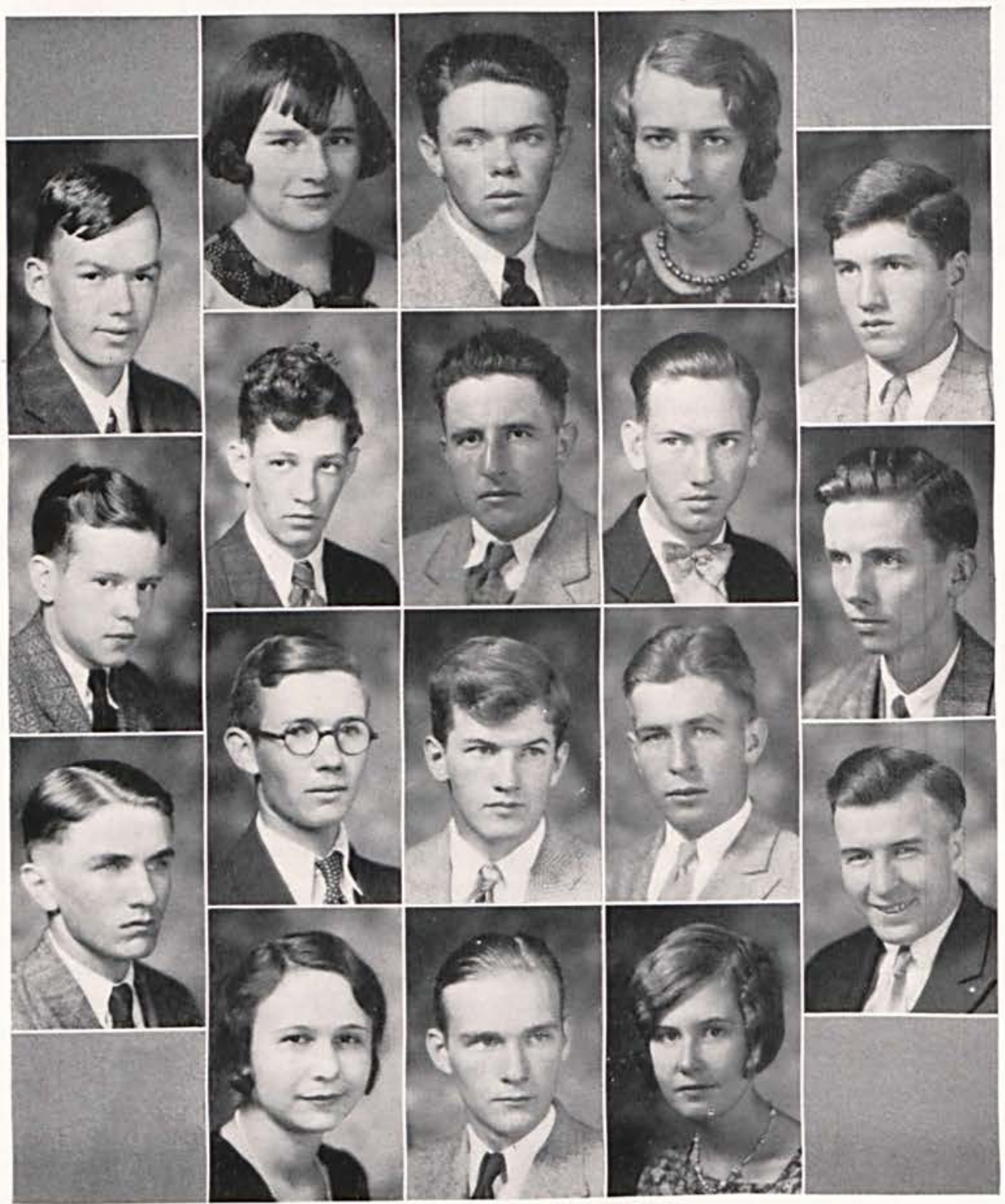

Martha Lackey, John Mills, Doris Hartman, W. Kilpatrick, Jo. Finney, Hutchison, Geo. Keunfield, Rob. Hopkins, W. Waddle, O. Dobbins, Malcom Finny,

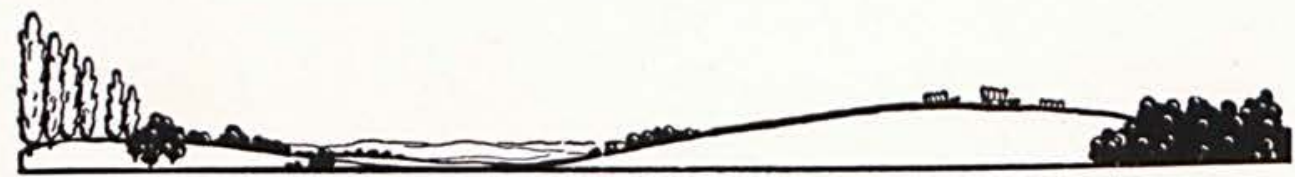




\section{Athletics}

Sports, true, noble, and fine,

Look us over and give us a hand,

We can prove it if you give us time,

As we have to many a man.

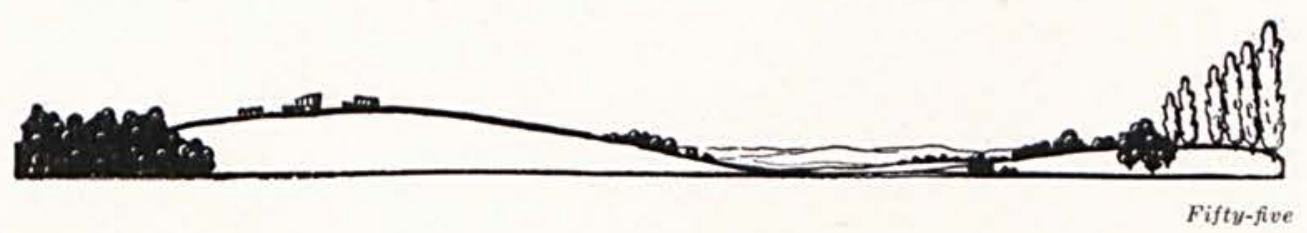




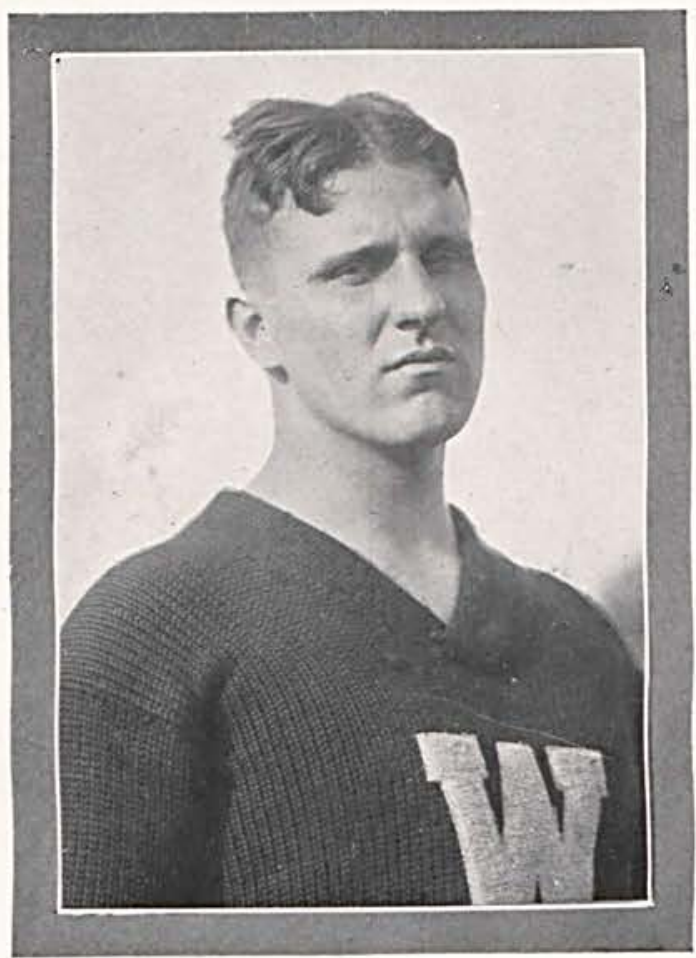

W

E take great pride in our athletic teams. We take pride in them not because of their victories but because of their spirit and type of play. Nowhere in the state of Ohio will you find a better spirited, cleaner group of athletes than you will find in Cedarville College. Our school does not engage in "tramp athletes" and there is no compensation whatever other than the love of the games and the enjoyment received from going out there and putting our heart out for old C. C. With this idea in mind we do fight our heads off to win. And we do it in the attitude which is found predominant throughout the whole college. The attitude of fairness.

The question is, who creates this attitude and spirit in athletics? The answer is, our coach. Coach Borst cannot be given too much praise for his never-ending work and success with the athletic teams. When you think of our athletic department, we ask you to please stop and consider just how much in debt we are to our coach. Let us all stand and give "Pops" a great big hand.

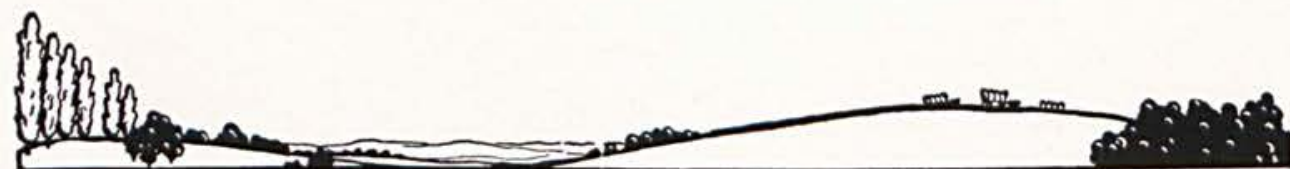




\section{E D R U S}

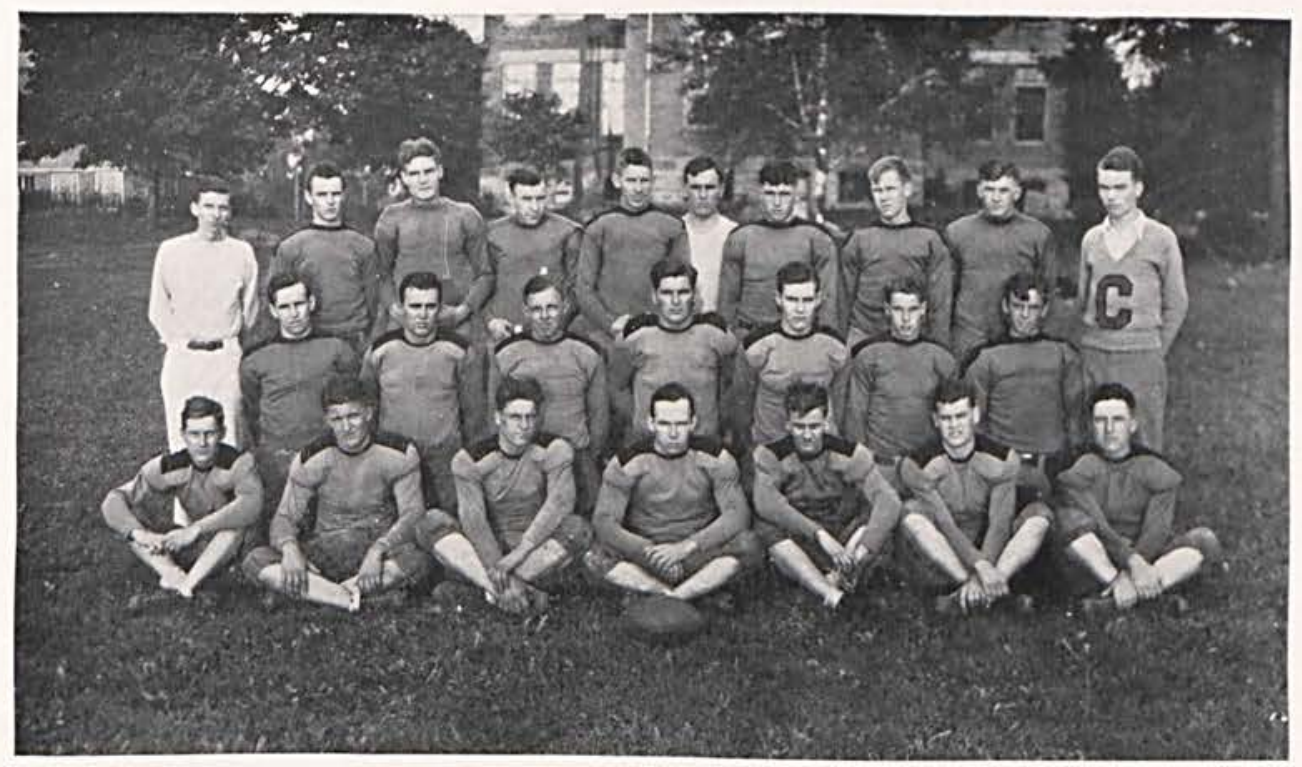

Standing-Manager Waddle, Bull, Ballard, Murray, Gariow, Coach Bors:, Finay, Richards, Finny, Manage: Hostet.er.

Krceling-Osborn, Hinten, Turner, Irons, Townsiey, Grant, Rife.

Sitting-Allen, Idding., Collins, Stormont, Wait. Boyer Wend. Boyer, Kennfield.

\section{Football Review}

$\mathrm{T}$

HE Cedarville College football team experienced a successful season, although winning only one game and tying another. The team was scrappy at times and at other times played listless football but most of the time the boys made touchdowns difficult if not hard for the opposing team to get. They were out there doing their best which is all that can be asked of anybody. Considering the schools we met, their size and their superior numbers, and Lady Luck, Cedarville experienced a successful season.

Our team played practically the same class of schools as last year. Two Ohio Conference teams, Cincinnati University and Otterbein, Wilmington, Urbana Junior College, Rio Grande and Morehead State at Morehead, Kentucky, were played. The scores on the average were smaller than those of last year indicating a somewhat better team. This was to be expected as we lost only two members from last year's squad.

The opening game with Cincinnati was quite different from last year. Our boys were playing their first game of the season, practically their first hard scrimmage. So we lost 46 to 0 . Quite different from the score of 19 to 0 of last year.

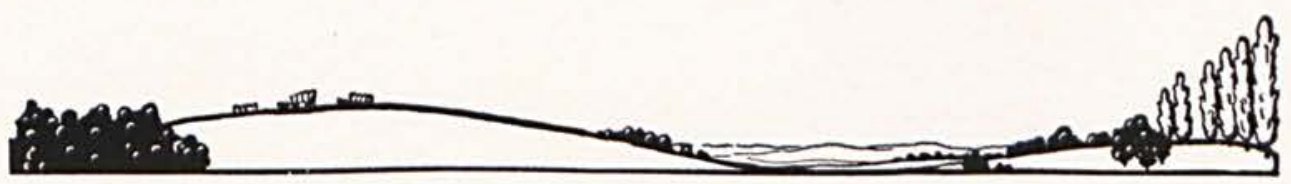


At Otterbein, Cedarville actually met the proverbial "steam roller." The entire line averaged well over 200 pounds, the tackles weighing 245 and 250 . Even so, our boys held them to one touchdown in the first half. The final score was 25 to 0 .

Our first home game was with Urbana Junior College. Urbana scored first and it looked for awhile like Cedarville would not score at all, but in the last half a punt was blocked and the fellows converted it into a touchdown in a few plays. The goal was missed and we had to be content with a tie score 6 to 6 . The return game at Urbana ended 12 to 0 in their favor.

Wilmington defeated us twice, the first time 20 to 0 and the second 12 to 7 .

The high spot of the season was the victory over Rio Grande, there. The last time Cedarville played football there the score was-painful to recall. But we got partial revenge by defeating them 34 to 0 . If the team had been feeling as good and working so well together in some of the other games as they did in this one more would have been won.

The season closed with a game at Morehead, Kentucky. After the long trip the boys could not seem to pull together and play ball so we lost 7 to 0 .

When schools we played found out we had an enrollment of only 75 or 80 they shrugged their shoulders as if to say, "Here is another easy victory." Before the smoke of the battle cleared away they usually changed their opinion of our school and our boys. We may be small in numbers but when it comes to fighting there are very few who can beat us.

J. C. S.

FOOTBALL SCORES

$\begin{array}{lrlr}\text { Cedarville } & 0 & \text { U. of Cincinnati } & 46 \\ \text { Cedarville } & 0 & \text { Otterbein } & 25 \\ \text { Cedarville } & 6 & \text { Urbana } & 6 \\ \text { Cedarville } & 0 & \text { Wilmington } & 20 \\ \text { Cedarville } & 34 & \text { Rio Grande } & 0 \\ \text { Cedarville } & 0 & \text { Wilmington } & \\ \text { Cedarville } & 0 & \text { Urbana } & 12 \\ \text { Cedarville } & 0 & \text { Morehead } & 7\end{array}$

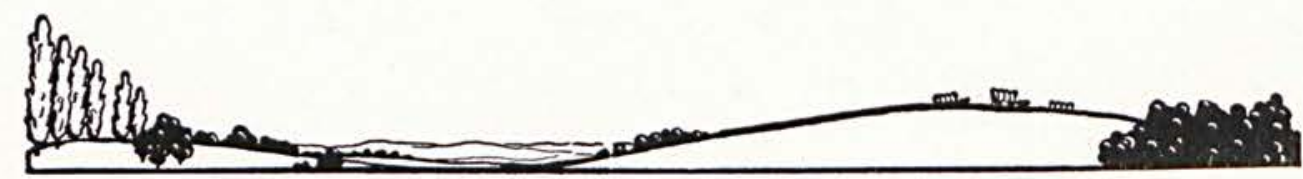



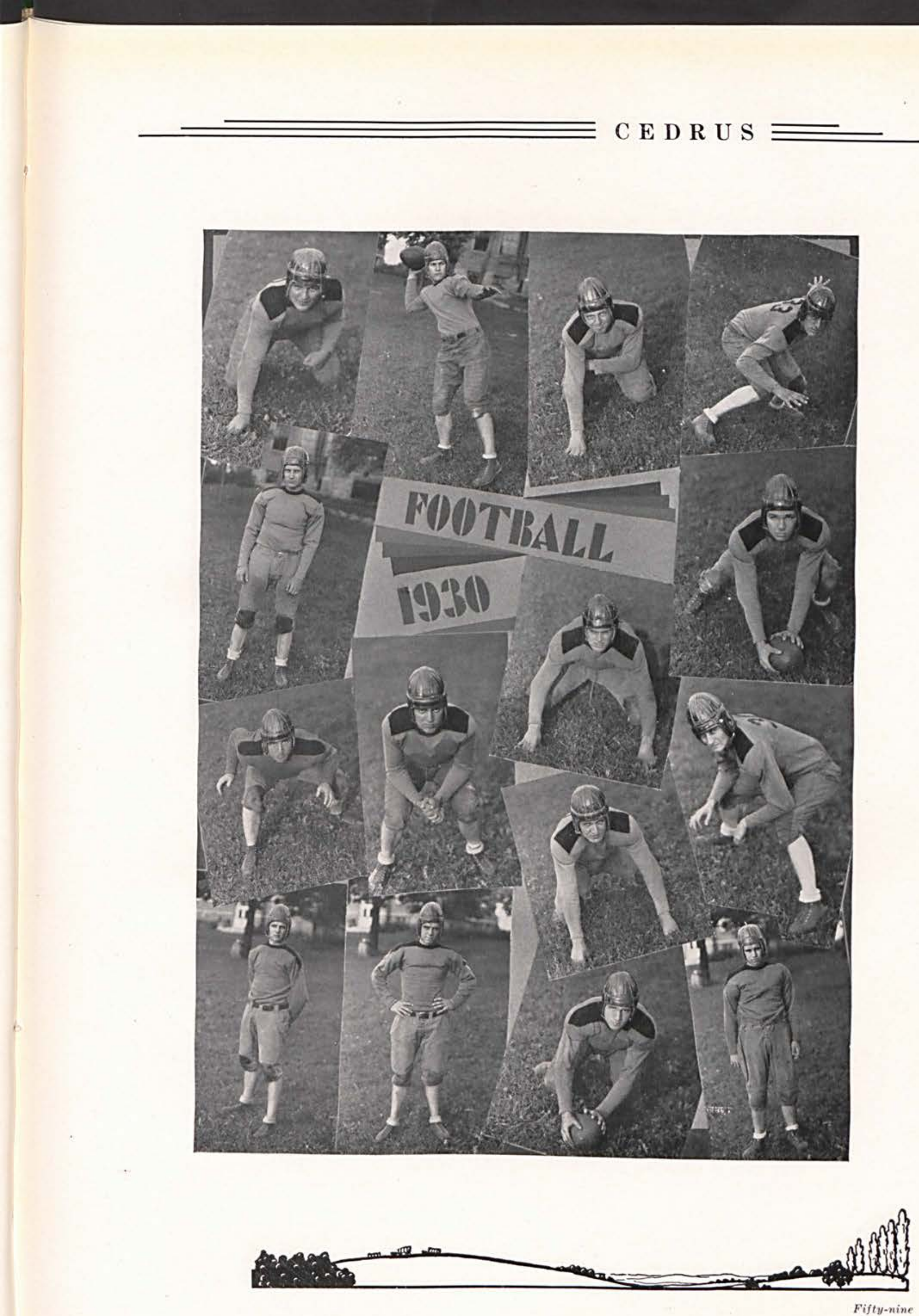


\section{E D R U S}

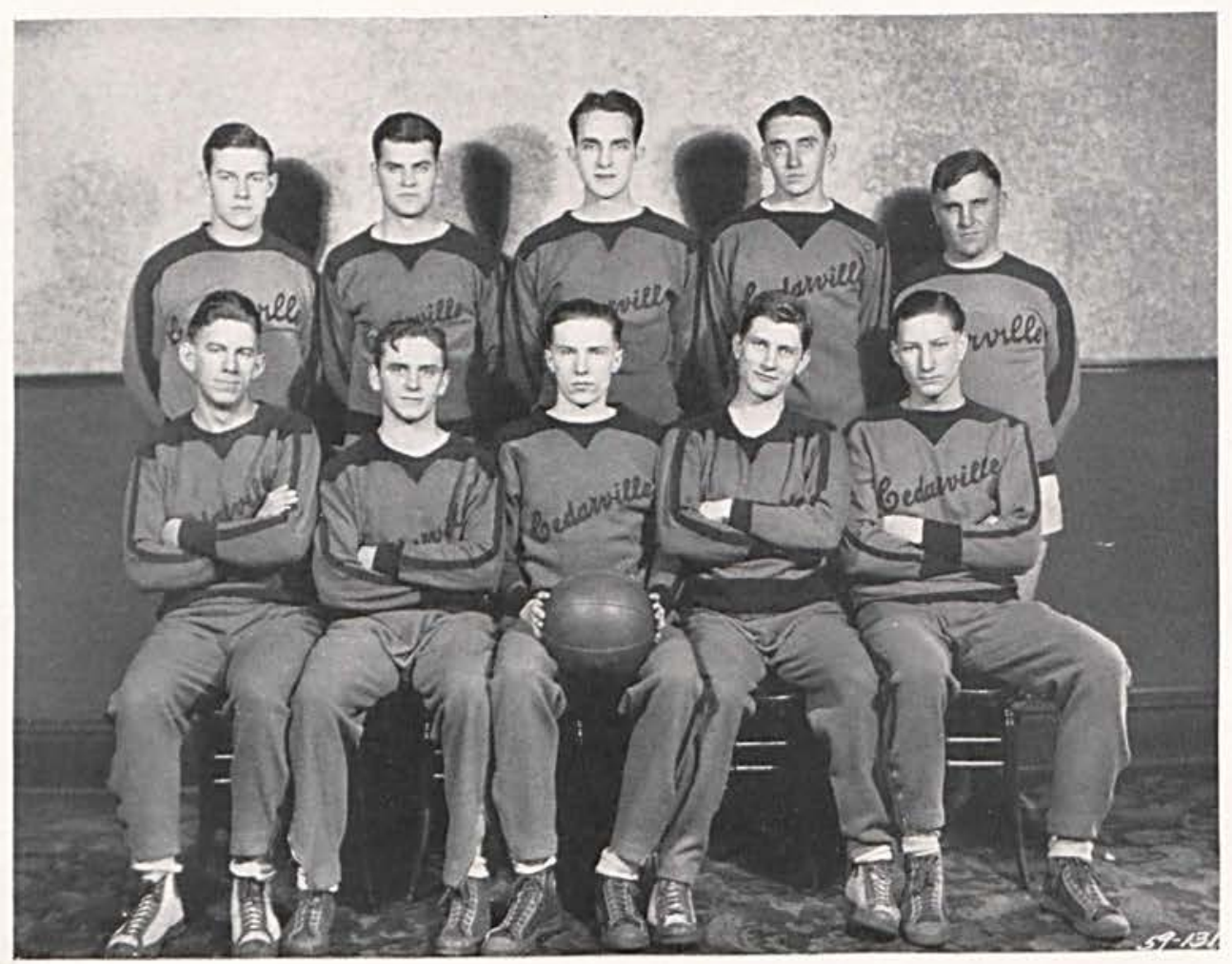

\section{Basketball Review}

\section{0-1931}

$\mathrm{P}$

ROSPECTS for the season of 1930-31 were bright when the season started. With the return of nearly all of last year's squad and the addition of new material C. C. expected to experience the best season in the history of the College. Playing some of the foremost teams near our size in our state we did very well to win five victories. We lost a game to the University of Dayton and the Homecoming game to Antioch by one point and two points respectively.

Several other games would have been won if everyone had been at his best. But no ball club can be "hot" all the time.

The season opened with the first seven games being lost. Then it seemed as if we might be going good as we won the next two games from Urbana and the return game with the University of Dayton. However the next two games were dropped by decisive scores.

We won from Wilberforce here in a fast and furious game, 31-30, and from Antioch, there, 31-26. Only one game was won the rest of the season and that from Urbana, there.

The crowds attending the games were small and consequently very little money

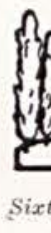




\section{E D R U S}

was made this year. The students and people of the community must take more interest in basketball if it is to be a financial success. Cedarville College has a team nearly every year which any school of three or four hundred students would be proud to support and it is up to the students to see that the team is backed to the limit.

The prospects for next year are not very bright as we lost Wendall and Walter Boyer, Alfred Townsley, Albert Turner and Robert Collins by graduation. But we have excellent Sophomore and Junior material to step in and take their places.

We must take this opportunity to thank Coach Borst and the squad for their faithful and successful upholding of Cedarville College's honor and name on the hardwood courts of Ohio and the neighboring states. These men have always been clean and fair players upholding Cedarville College's name and traditions wherever they played ball.

We wish the squad and Coach Borst the very best luck in their next year's basketball season and may they spread the name and fame of Cedarville wherever Collegiate basketball is played.

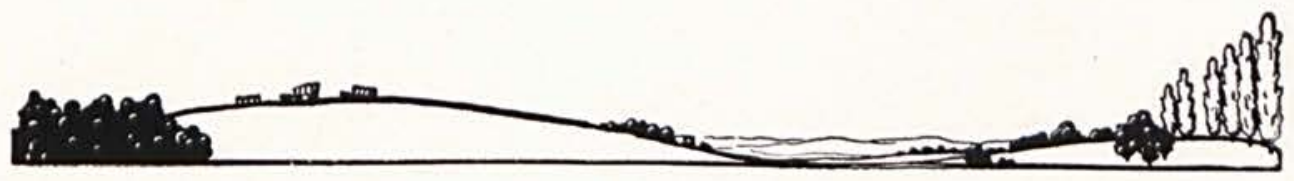




\section{Scores}

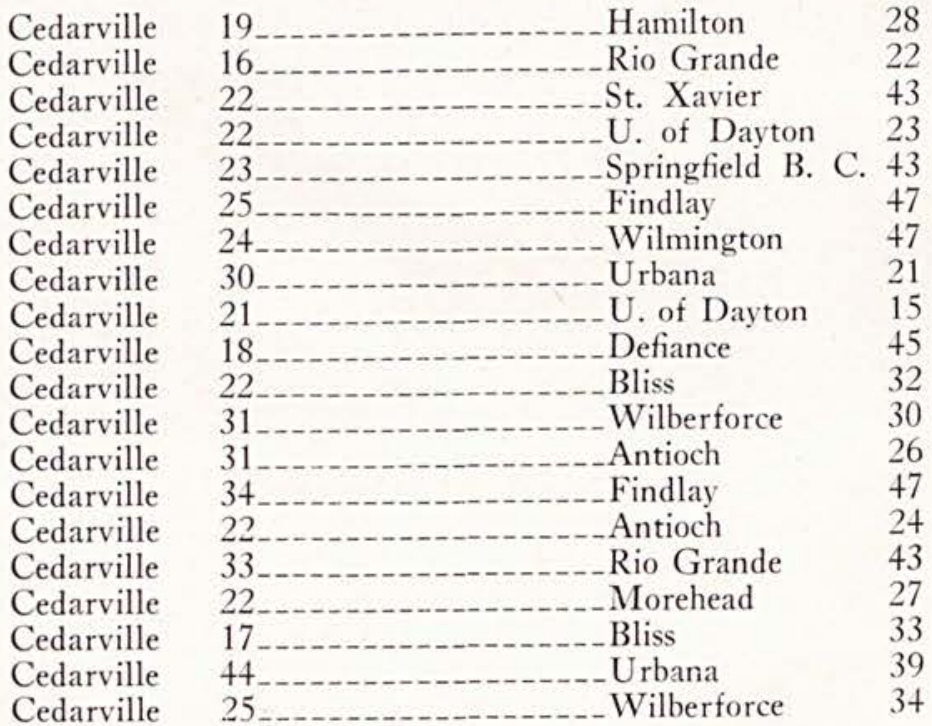

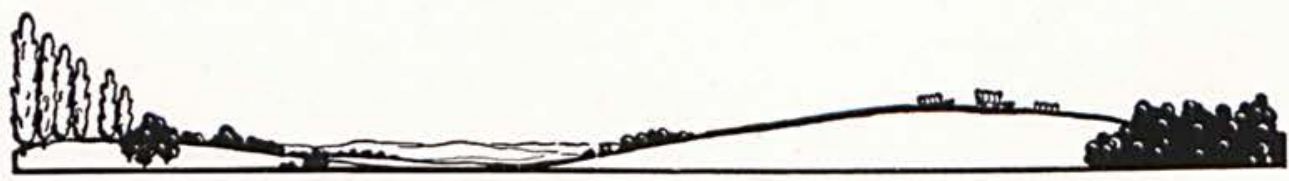



They returned to Columbus a far less "cocky" bunch than arrived here for the game and realizing that at least occasionally they play some real baseball at Cedarville.

One of the closest and most exciting games was with the heavy hitting Wilberforce team. Our boys went down to Wilberforce and not only held them even as far as fielding and pitching are concerned, for we pride ourselves on our defensive work, but we also outhit this powerful crew and brought home the winning baseball.

Our closest rival, Antioch, fell before our team and last but not least, Wilmington was actually defeated by Cedarville, and it was done fairly and squarely, too, although Wilmington tried to make some new rules in the last couple of innings, but the umpires were wise to their tactics and it availed them nothing. Perhaps this will break the long spell that Wilmington has held seemingly over all athletic teams representing Cedarville.

The only Senior we lose by graduation is Paul Tanner our right-fielder, so at present with at least eight veterans remaining it looks as though Cedarville College should have a banner year in baseball for 1931, and I think everyone will join me in saying that we are truly proud of the 1930 record and now look forward with great hopes and aspirations for the coming year.

B. T.

\section{Good-bye "Pops"}

$\mathrm{T}$

HERE are seven members of the Athletic teams who graduate from the halls of old C. C. this year and we wish to take this time and space for these seven Seniors to say good-bye.

Four long years ago we started together, playing, fighting, endeavoring to put Cedarville College Athletics on the map. We have learned to love our Coach and each other. It is hard to shake the hand of Coach Borst and say good-bye without shedding a tear. But of course we must; as our ways are doomed to part. We shall carry fond and aching memories from our Athletic experience, memories which we shall probably brood over for a very long time. But let us hope that some day in the future we can have a sort of get-together and do a little, "Do you remember the time when-? etc., etc.

We say good-bye to you "Pops" and we say good luck. We wish we could be with you another year.

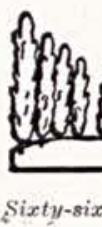




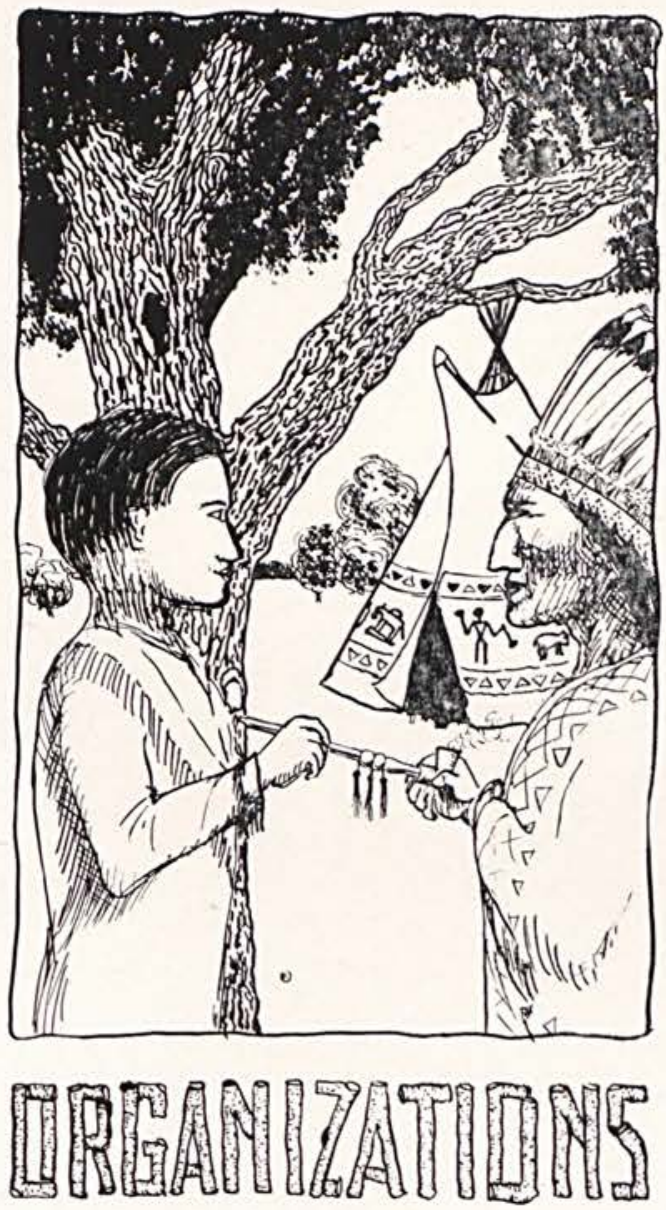





\section{Organizations}

Co-operation in organization we learn, is ideal.

We need not tarry to prove to you

That we attack things with zeal.

We shall prove to you in the following pages

That our noise is not all squeal.

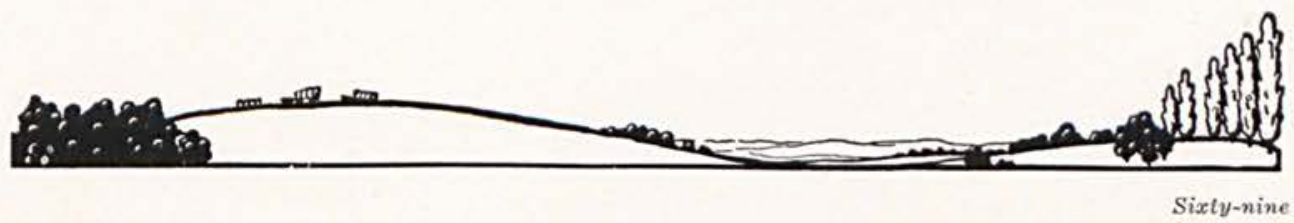




\section{E D R U S}
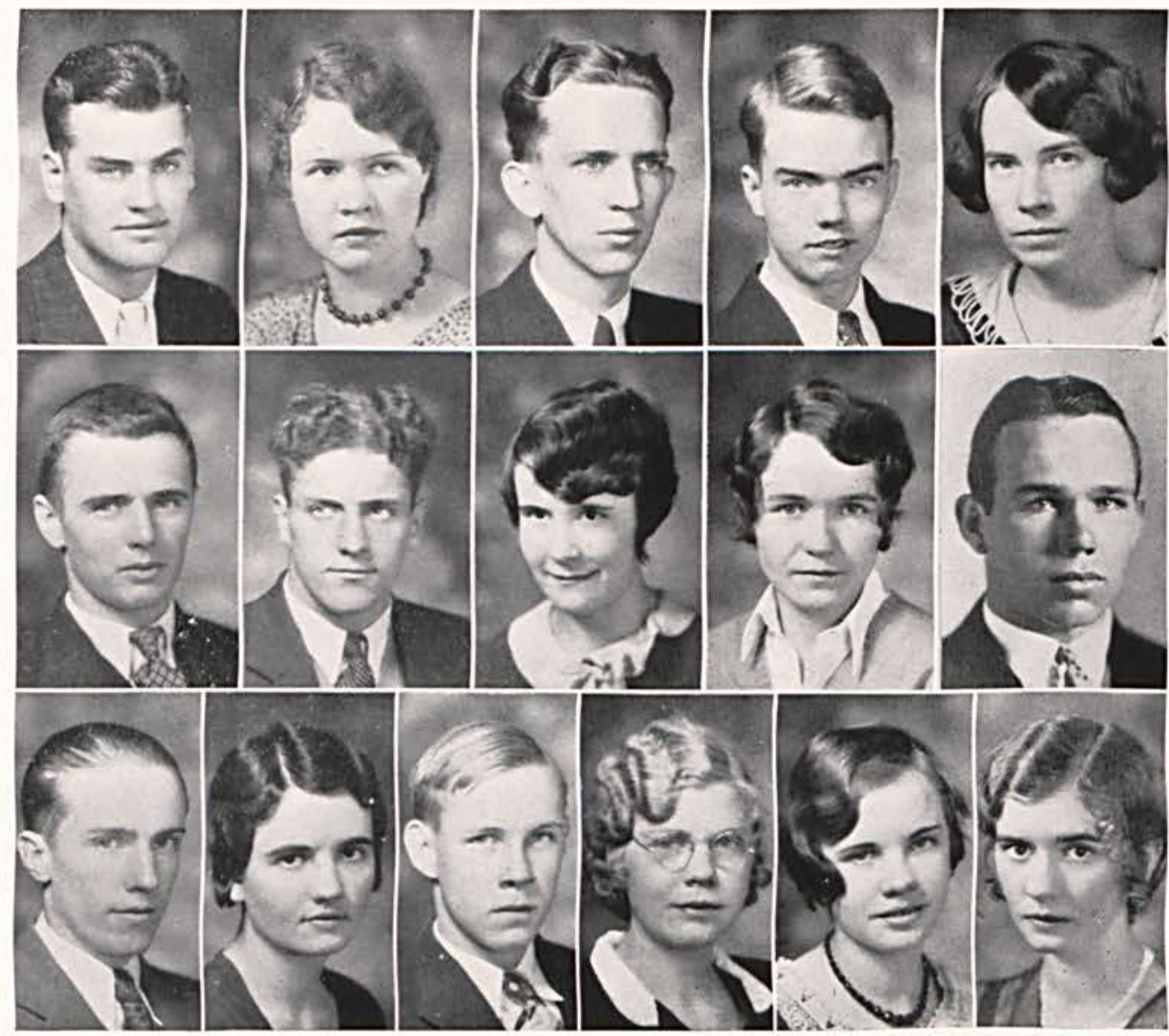

\section{Cedrus Staff}

$\mathrm{L}$

ATE nights, arguments, cramped fingers, hard work, worry, sacrifice, co-operation and much planning have all had their place in the publishing of this book. We hope that it comes somewhere near the high standard which has been set for it in the past. If pleasure or enjoyment is by any chance received from it, we wish you would kindly mention it to any member of the staff, who has been so kind and careful in working toward the completion of the book.

At this time we wish to thank very kindly, all those who have in any way helped in the making and publishing of this book.

We wish to especially mention and thank Miss Helen Baker and Miss Irene Tobias for their labors and to point out our selection to the post of honor which bears the insignia "a bear for work." Mr. Marion Hostetler.

I might add, if you want to wish upon some one of your enemies something real bad, wish upon them the editorship of the Cedrus.

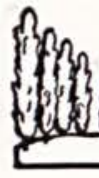


We wish to again thank all those who have had anything at all to do with the making of the Cedrus. And we wish you a very pleasant summer. Have many, many experiences and when you come back to school next fall you can astound the boys sitting down at Doc's when you tell them.

Wendell Boyer Editor-in-Chief

Gertrude Martin Assistant Editor

Vernon Hickman Business Manager

Marion Hostetler Art Editor

Carmen Frazier Social Editress

Edwin Bull Assistant Advertising Manager

Robert Collins Advertising Manager

Doris Swaby Diary

Wilda Auld Girls Athletic Editress

James Stormont Boys Athletic Editor

Robert Wilson Humor Editor

Lenora Skinell Music Editress

Robert Richards Assistant Business Manager

Ruth Marshall Snapshot Editress

Rachel Daulthet Snapshot Editress

Ruth Bradley Snapshot Editress

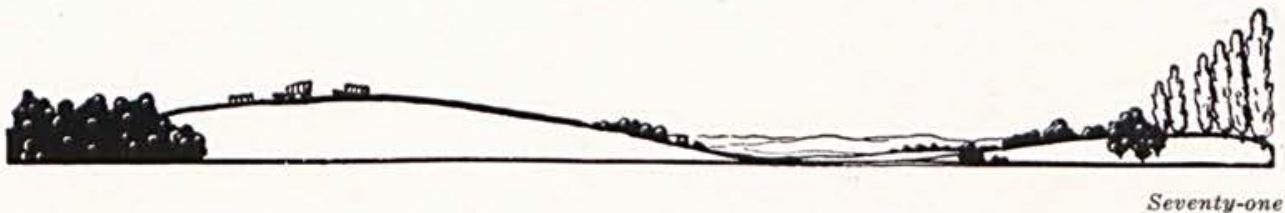




\section{E D R U S}
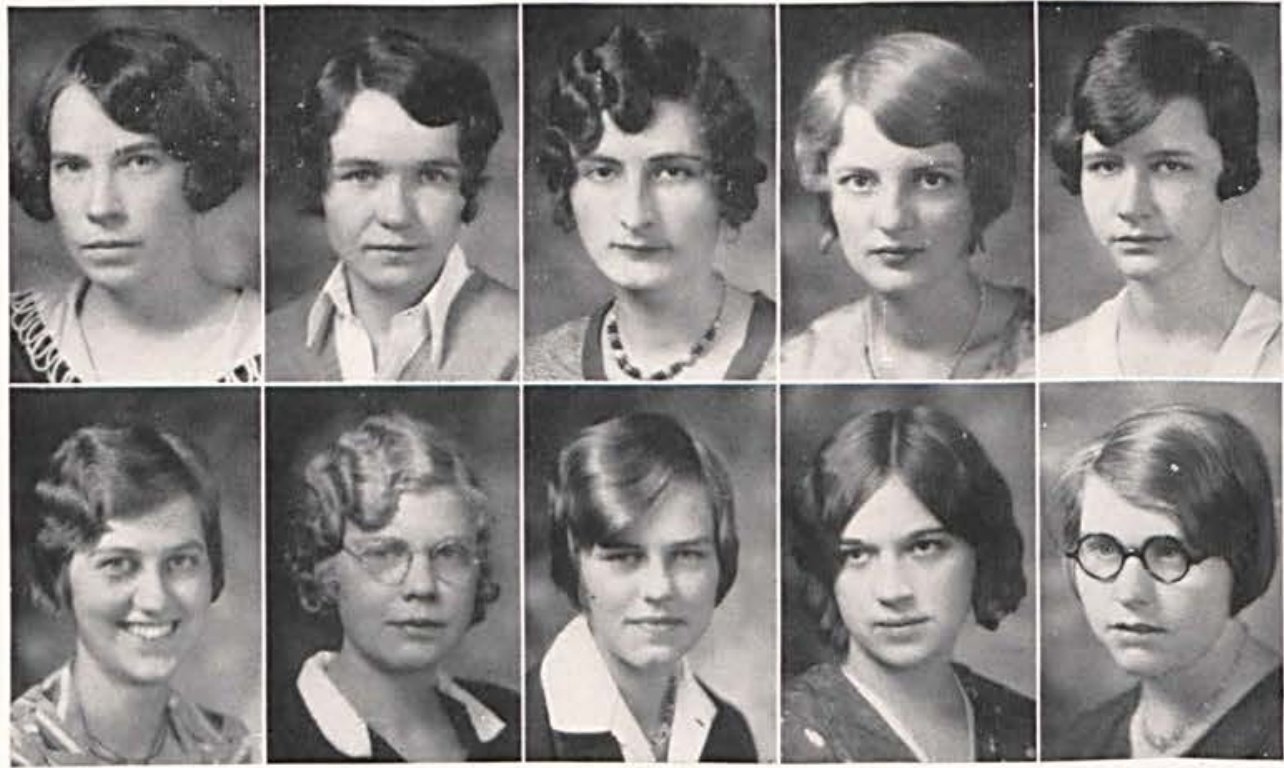

Y. W. C. A.

President Carmen Frazier

Vice President Wilda Auld

Program Chairman Eloise McLaughlin

Secretary-Treasurer Mildred Carle Finance Chairman Sarah Rumbaugh Social Chairman Sarah M. Chance Social Service Chairman _artha Waddle Foreign Relations Ruth Marshall Publicity Chairman Bernice Bryant

Hostess Chairman Wilma Curry Faculty Advisor Dorothy Angevine

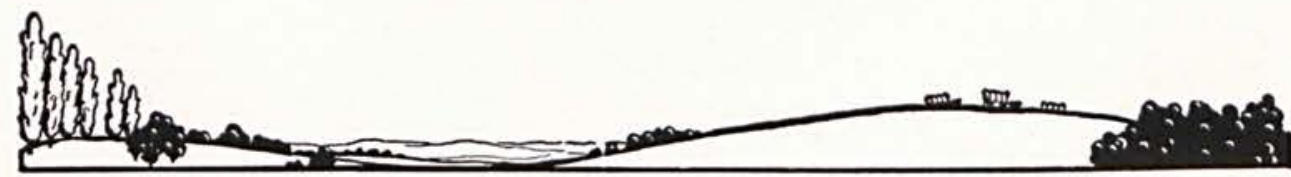




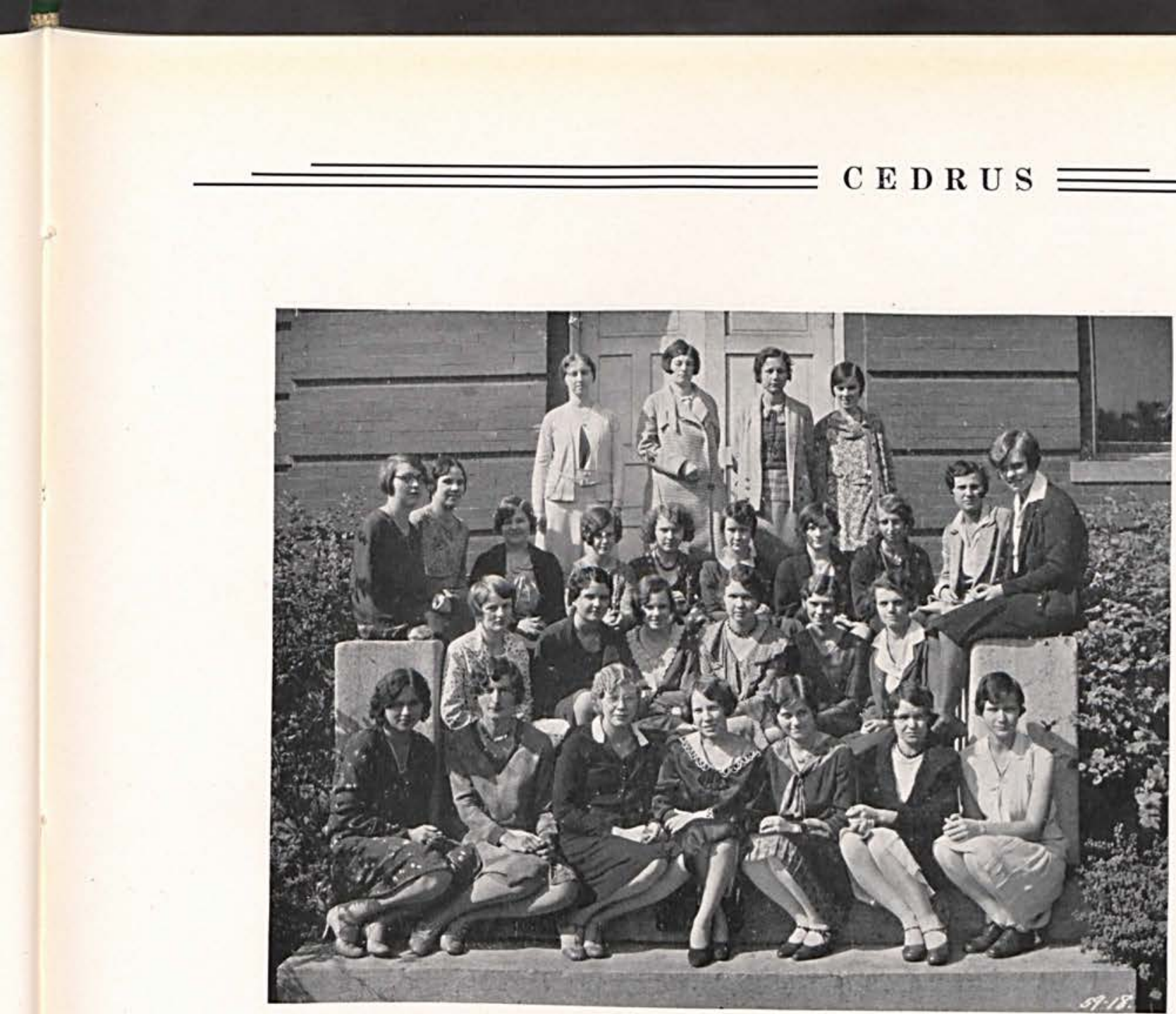

\section{Young Women's Christian Association}

$\mathrm{T}$ HIS has been a difficult year for the Y. W. C. A. owing to the decreased number of girls in the college and the general financial depression. However, we have had much to be thankful for. Our small number has enabled us to drop formality and to have round table discussions at our weekly meetings. Some subjects discussed were: Marriage ruins career; Good Sportsmanship; Boy and Girl Relations et al., and we derived much benefit and pleasure from these meetings. Some projects presented this year were: Art Appreciation, Music Appreciation, Beauty Culture, Physical Culture, etc.

As money-making scheme we sold hot dogs on business days, and in November we successfully held a Waffle Breakfast inviting the public. This last was an entirely new scheme but it proved to be so successful that Dr. Mac requested that it become an annual event. We were able to send thirty dollars to the National Board.

In a social way we have held a number of Cabinet parties and get-togethers; we sponsored the college Hallowe'en Party; worked co-operatively with the College Y. M. C. A. several social occasions. We held an unusually fine Mock Wedding this year and now we are planning our annual Mother and Daughter Banquet to be held May 8.

C.F.

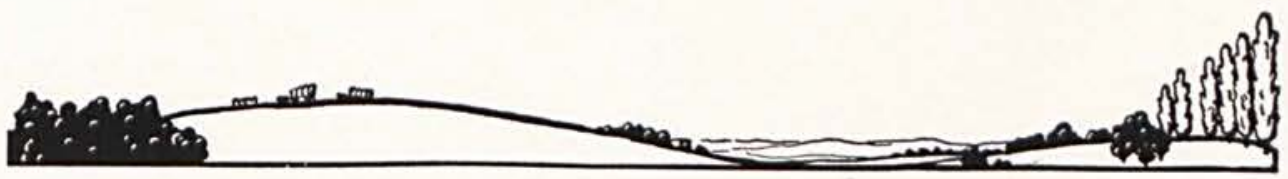



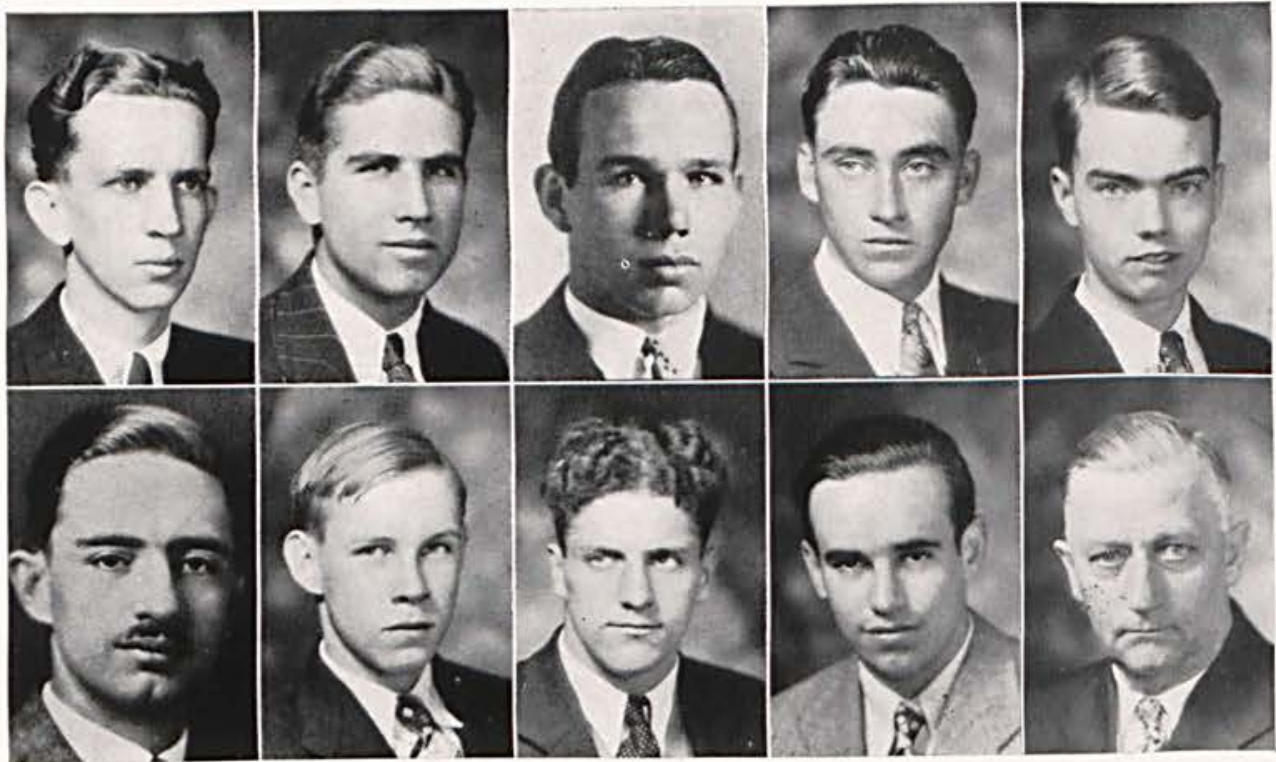

Young Men's Christian Association

Vernon Hickman President

Brenton Turner Vice President

James Stormont Secretary

Charles Spencer Treasurer

Marion Hostetler Program Chairman

Prof. Kuehrmann Faculty Advisor

Robert Richards Social Chairman

Robert Collins Program Chairman Jack Osborn World Affairs Chairman

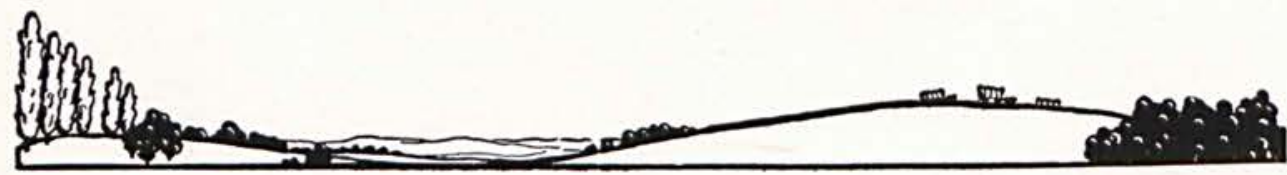




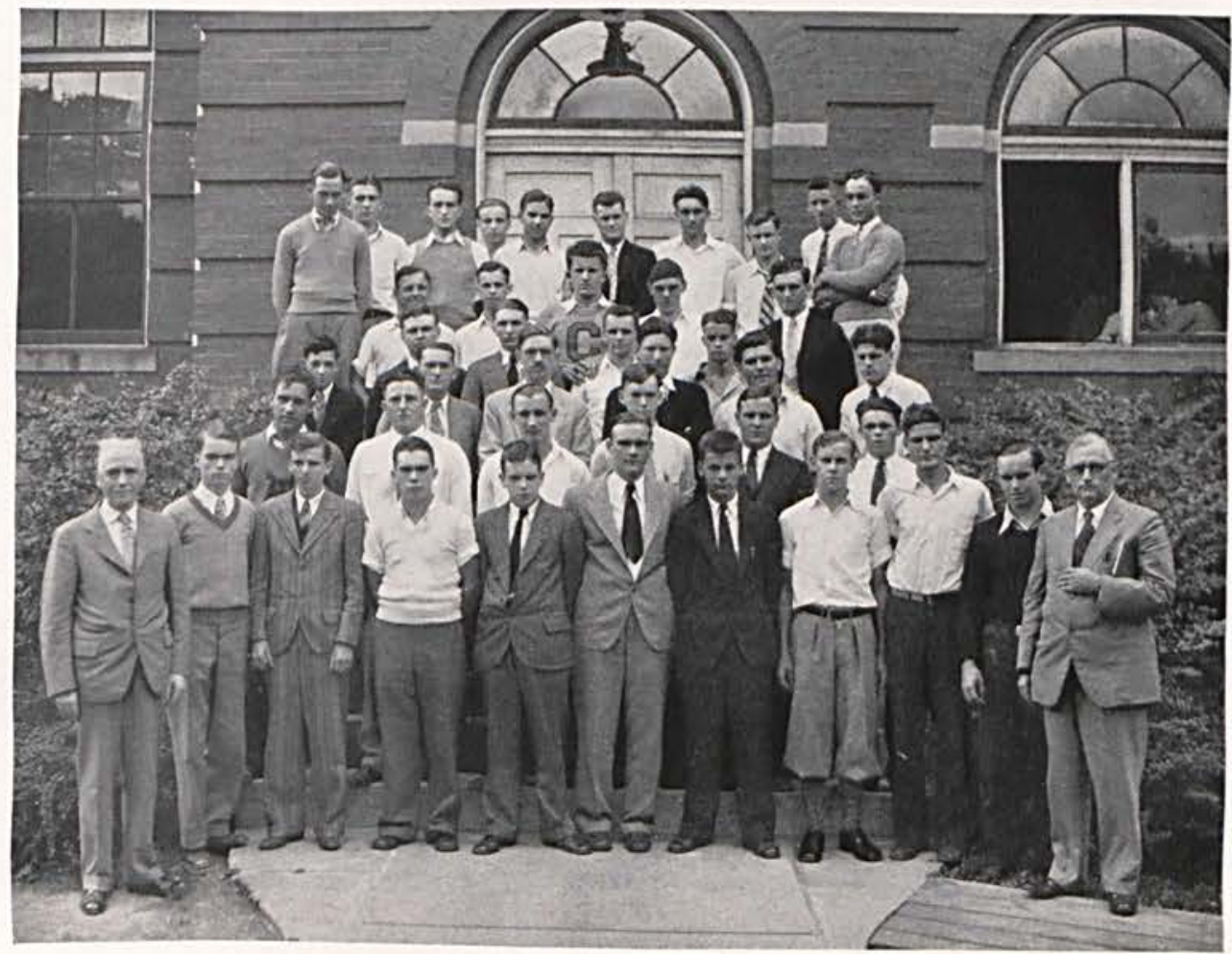

\section{Y. M. C. A. Notes}

7 HE Y. M. C. A. is one of the major organizations of Cedarville College. It has for its duty and aim the building of strong spiritual characters in the young men of the College. For this reason it holds its importance with scholastic and athletic organizations.

The efforts of the program chairman have been to promote a keen interest in the meetings by calling in men of the professional walks of life along with well-known ministers of the surrounding communities.

We have had several student-led discussion meetings this year. All these meetings we feel have been intensely interesting, and the members have attended very faithfully.

The Y. M. C. A. and the Y. W. C. A. have always enjoyed perfect co-operation. This year has been no exception to the rule. Our several joint meetings have been very successful due no doubt to the availability of more talent.

The Y. M. C. A., with the Y. W. C. A. and the social committees of the student body has done much to keep up the interest of the students by the direction of social functions.

It is our sincerest wish that this organization for the furthering of Christ's Kingdom may continue to enjoy its prosperity in Cedarville College. May it continue to build Cedarville's men into chirstian leaders who will always honor their Alma Mater and its Y. M. C. A. organization.

J. R. C.

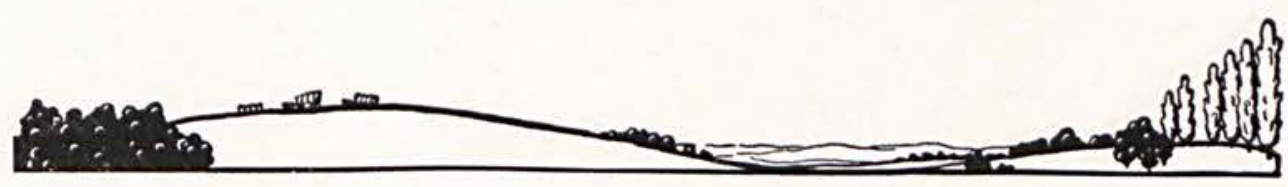

Seventy-five 


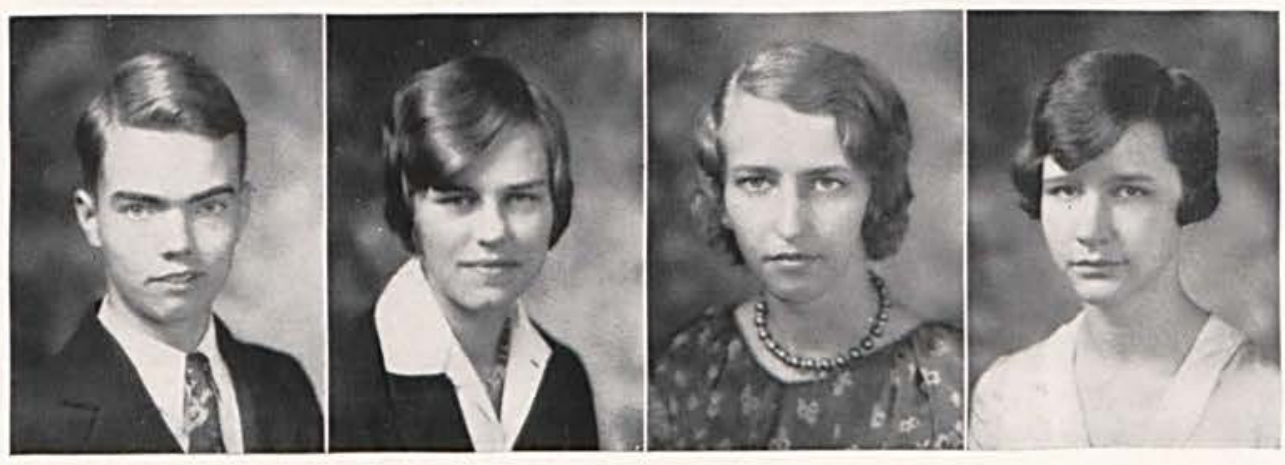

\section{Philosophic Literary Society}

Marion Hostetler President

Wilma Curry Vice President

Doris Hartman Secretary

Eloise McLaughlin Treasurer

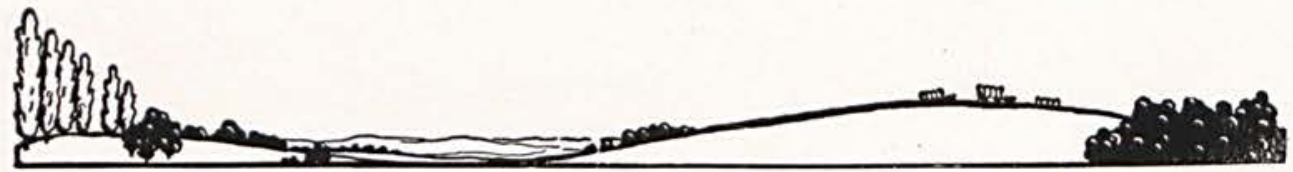




\section{E D R U S}

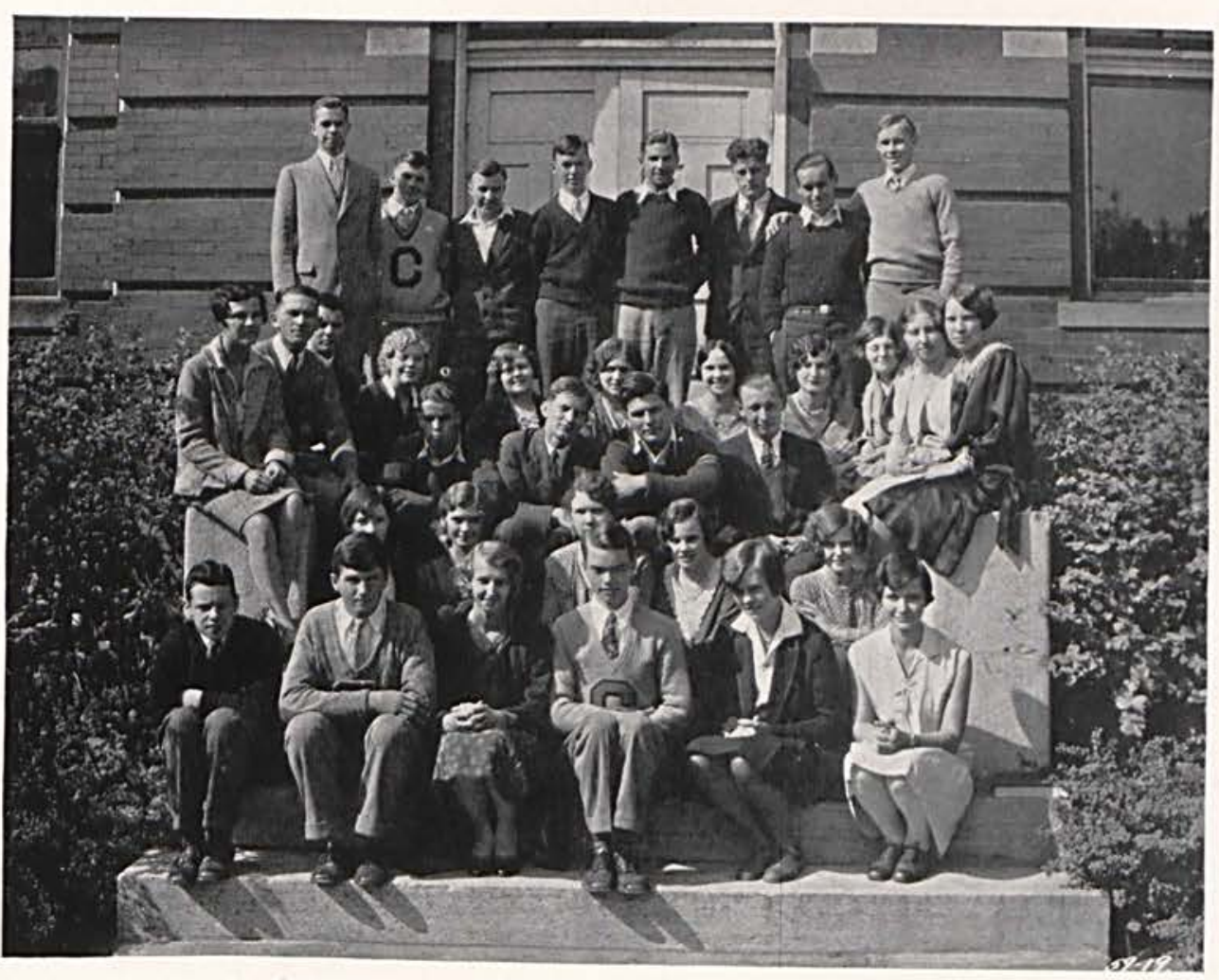

\section{Philosophic Literary Society}

T HE Philosophic Literary Society has no rival in the college, but even though it lacks the stimulus of competition it has enjoyed an active and successful year. Since membership is entirely voluntary, only those with mutual social or literary interest attend the meetings, so that a fine spirit of co-operation results.

The officers elected at the first meeting of the year were: President, Marion Hosttler; Vice President, Wilma Curry; Secretary, Doris Hartman; and Treasurer, Eloise McLaughlin. Three freshmen contributed their efforts during the year toward making the society a success: Chaplain Clyde Hutchison, who led the devotions; Sergeant-at-Arms Joe Finney, who arranged the meeting place and helped serve refreshments; and the Reporter, Walter Kilpatrick, whose items in the "College News" column of the local press were timely and well worded. All officers were re-elected for the second semester.

The programs consisted of talks, readings, debates, and short stories, as well as vocal and instrumental solos, duets, and ensembles. Some topic is carried throughout each program, and special features are frequently arranged. After Hallowe'en an impromptu mock trial was held, in which Carmen Frazier was charged with the theft of a traffic sign from a nearby village, but she was acquitted when she pled insanity. At the Thanksgiving meeting appropriate refreshments were served, and the Christmas program was presented at the Christmas party of the student body. An outdoor meeting at the Cliffs was quite successful.

Although the members undoubtedly gain practical experience in public speaking which will be of value to them in later life, the chief aim of the society is to have a good time in the living present and those who know agree that the aim was realized.

M. H.

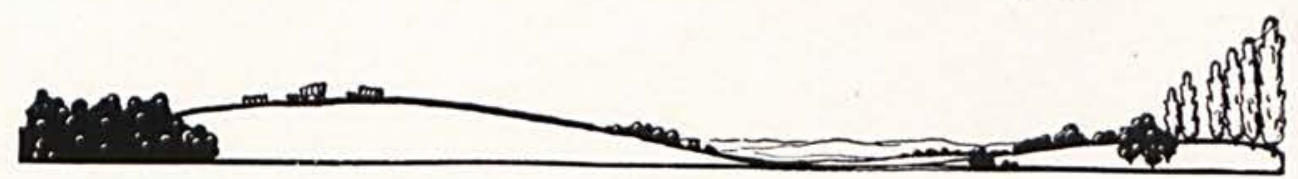

Seventy-seven 


\section{E D R U S}

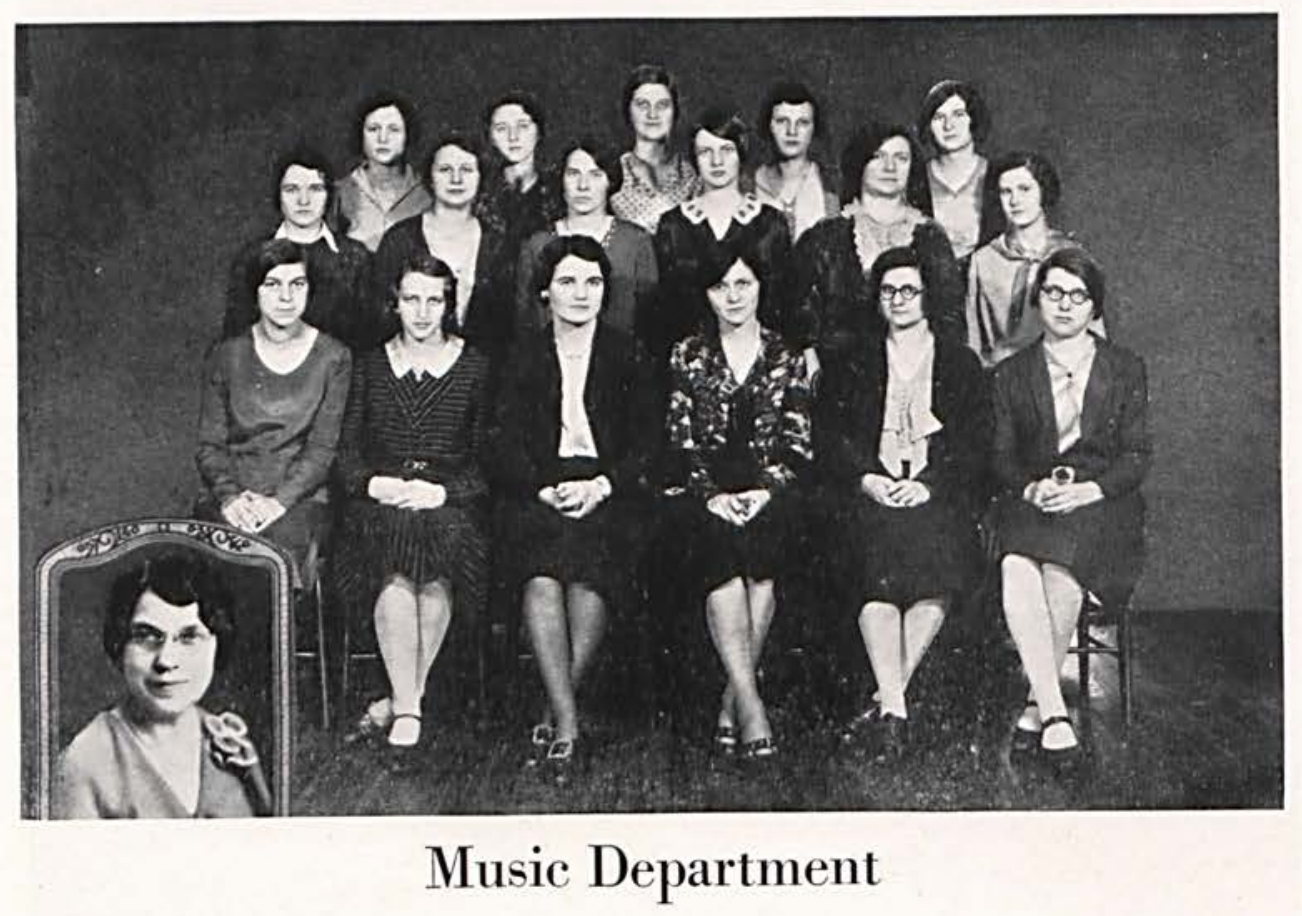

A LTHOUGH our Girls' Glee Club is smaller in number of members this year, we have been doing more advanced work. So far, we have filled no outside engagements, but our work here at home has been highly complimented. The mid-semester concert, with its variety of chorus numbers, solos, trios, quartets, and readings, was received with great appreciation by a large audience of music lovers.

The Department of Music, taken as a whole, has been larger this year than for some time. Several instrumental recitals have been given under Miss Berkeley's direction.

An added feature of interest in music has been the Reveler's Quartet, composed of George Gordon, Ed Irons, B. Turner and P. Garlough. This quartet has proven very popular and has given many outside performances. Also, this quartet, together with the girls' quartet, which is composed of Misses Waddle, Skinnell, Hartman and Stevenson, has accompanied Dr. Mac on several trips to various high schools where performances were given as advertisements for our college.

\section{L. S.}

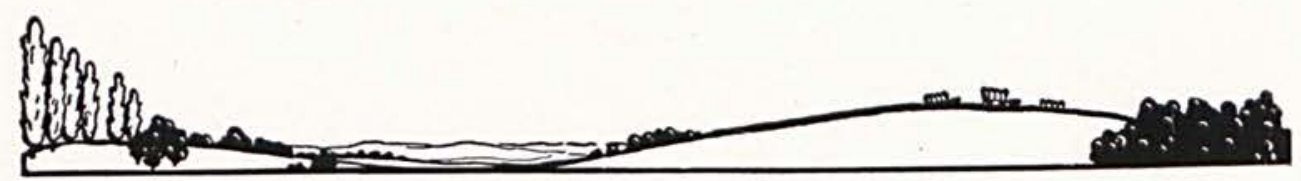

Seventy-eight 


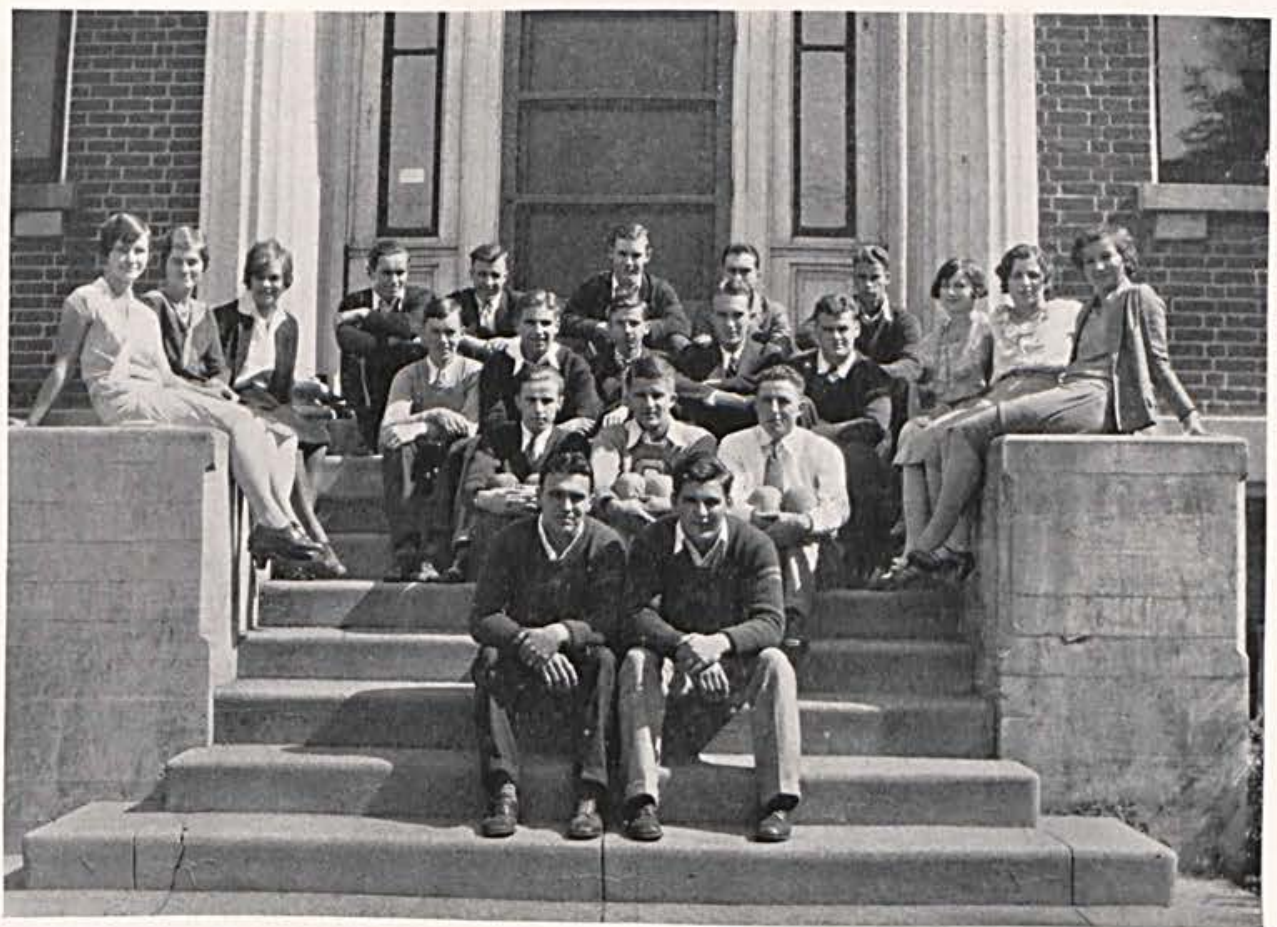

\section{College Club}

$\mathrm{O}$

$\mathrm{NE}$ of our favorite spots about college is the club located in the basement of the library. Every day the sound of the bell draws a hungry crowd around the dining room tables. It is here we learn to know each other well, for under the influence of plenty of good food we lower the bars of reserve and allow our true disposition to show forth.

Of course there is lots of teasing and joking going on while we eat, but experience has taught us to enter into the fun and contribute some ourselves.

We will all remember the place where we ate, drank and were merry.

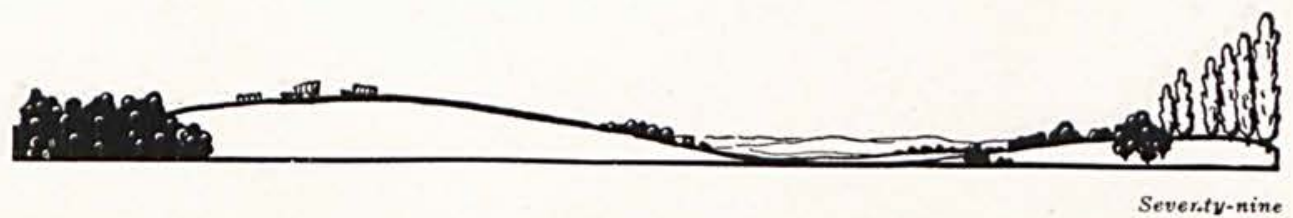



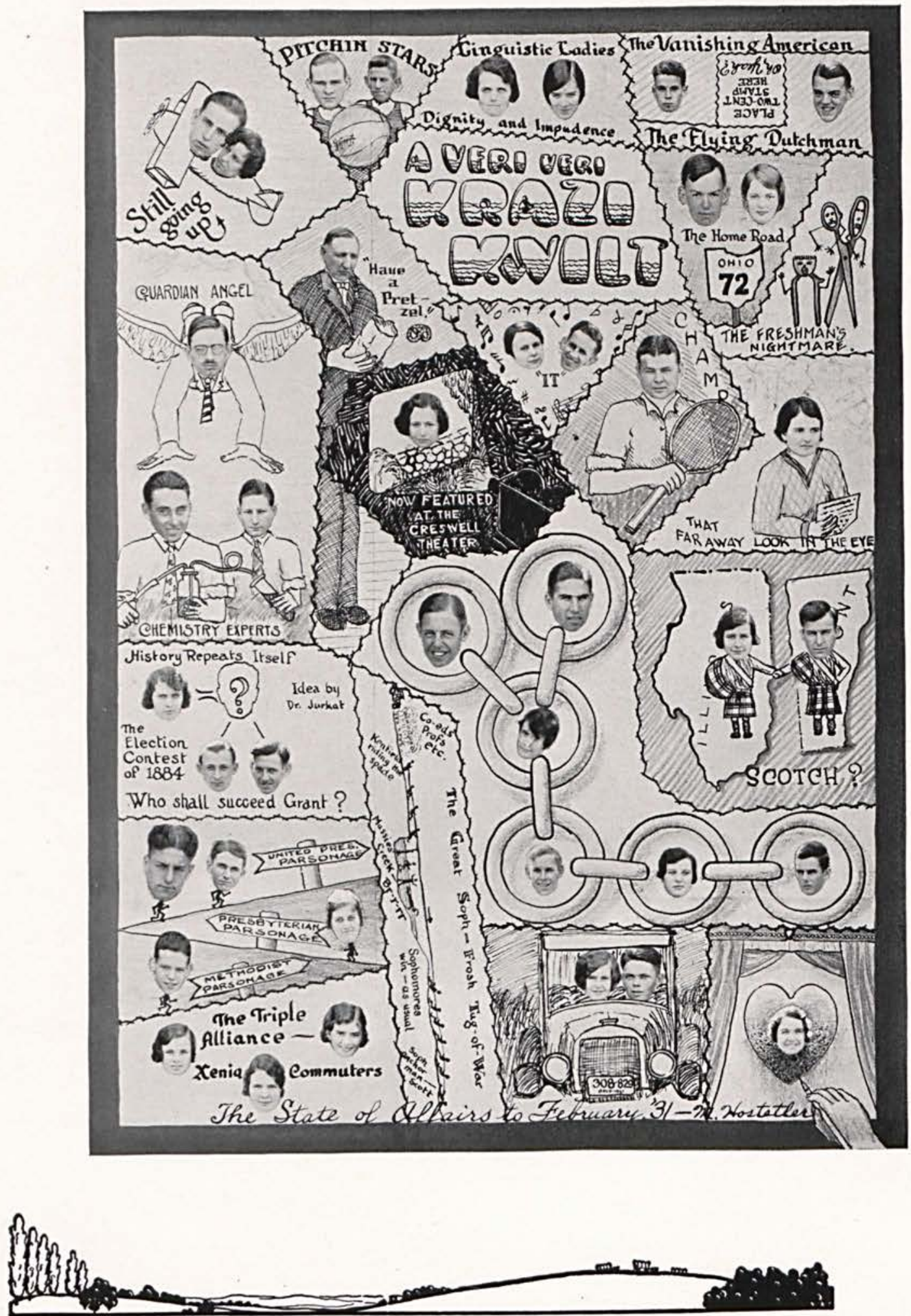


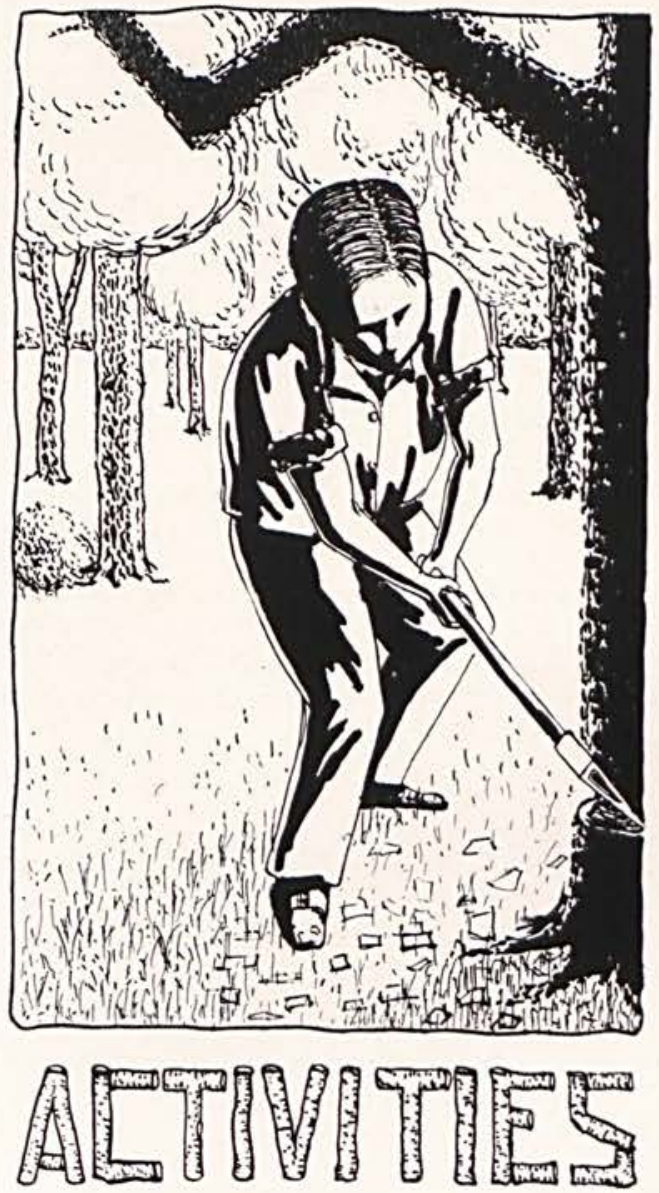




\section{Activities}

Active beings are we, a free will have we

We were given this by God and we use it constantly

It enters into our college work and in our play

We keep young and carry on by being active every day.

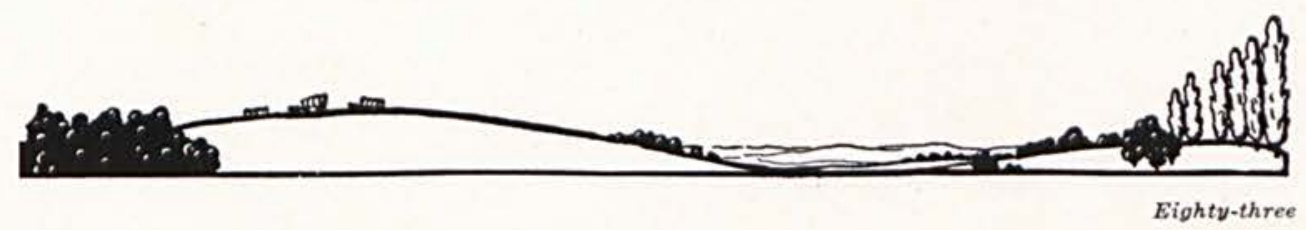




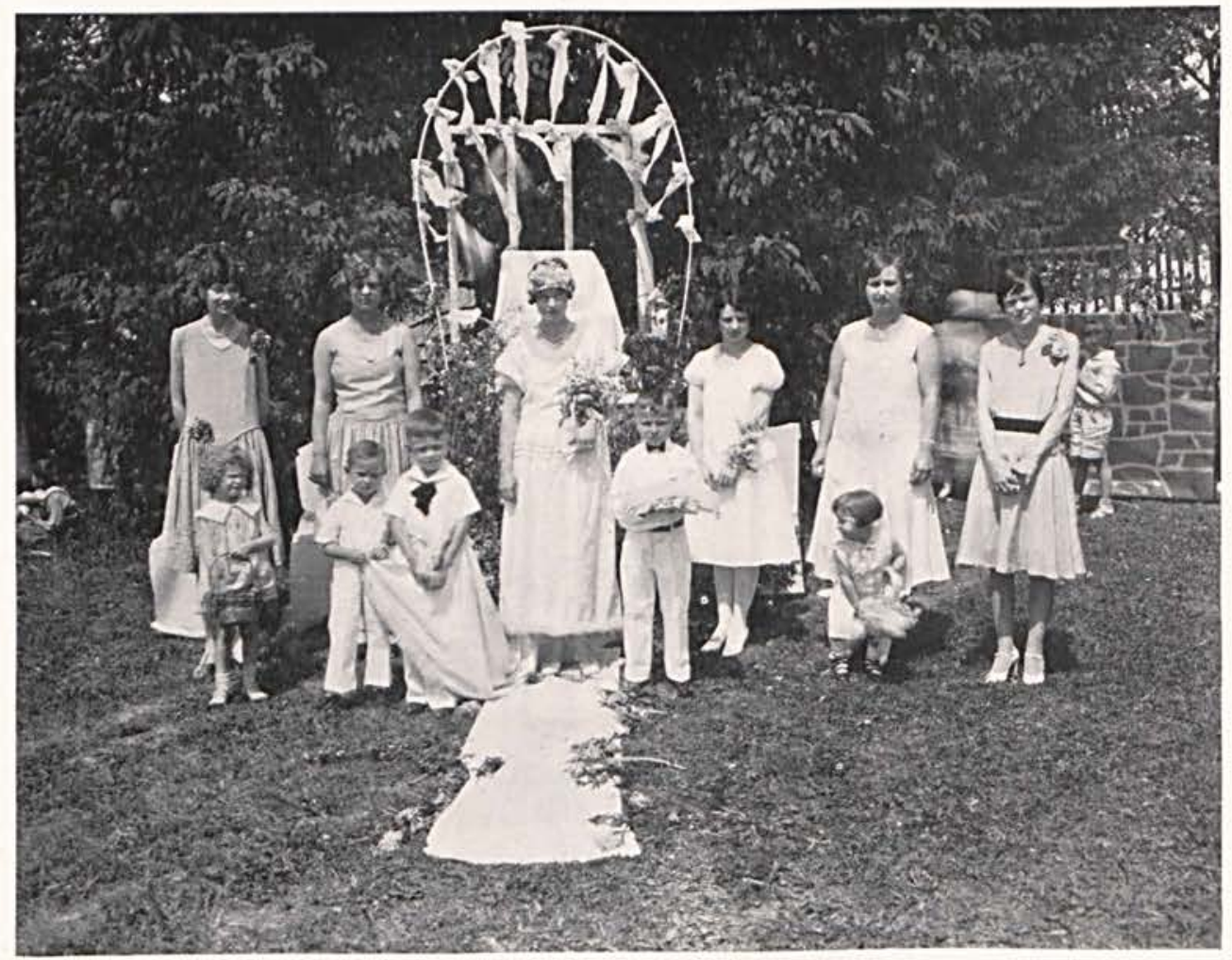

Queen thy beauty is to me

Like those Nicaean barks of yore,

That gently o'er a perfumed sea,

Thy weary wayworn wanderers bore

To his own native shore.

On desperate seas long wont to roam

Thy hyacent hair, thy classic face,

Thy Naiad airs, have brought me home

To the glory that was Greece

And the grandeur that was Rome.

\section{Lo! on yon brilliant throne}

How statue-like I see thee stand,

The Agate lamp within thy hand

Oh! Psyche, from the regions which

Are Holy Land!

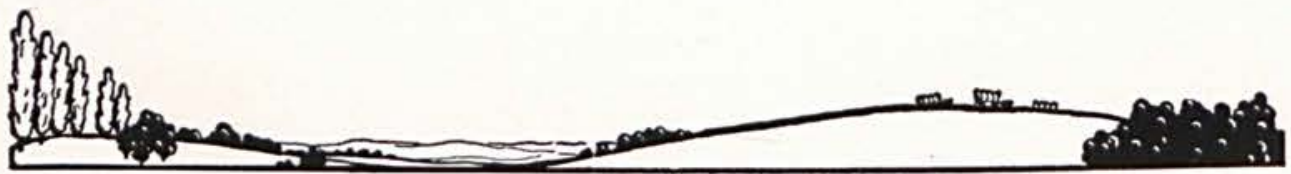




\section{Cedar Day 1930}

$\mathrm{N}^{\prime}$

INETEEN-THIRTY Cedar Day Exercises will never be forgotten by those present on that beautiful, sunshiny morning of June fourth.

Accompanied by beautiful and sweet strains of music the procession began. The beautiful queen, Lucile Tanner, knelt before a white, flower-bedecked throne, surrounded by her many attendants to be crowned by Miss Margaret Chandler.

Possibly one of the most outstanding memories of the day was the May Pole Dance. It was well done and worthy of high praise.

Praise was also due Herbert Main, the orator of the day. All those present were permeated with his dauntless hope, vision, loyalty, enthusiasm, and undying love for dear old C. C.

The theme of the remainder of the exercises was Spring. Villagers were on the green, dancing to invoke the arrival of Spring. When Spring did not come they went away to the woods in search of it. They found many signs of Spring, the violet dance, the butterfly dance, the tree nymph dance, and the Spring flower dance, but none of these brought the spirit of Spring, (Rachel Douthett). The Wild Rose (Jean Morton) brought the Spirit (solo dance).

The spirit of Spring entered attended by sport (stunts), Wanderlust (gypsy dance) and romance. The Wild Rose and the Spirit of Spring then danced accompanied by the villagers and dancers.

\section{CEDAR DAY COMMITTEE}

Coach Borst, Mrs. Borst, Rachel Douthett

Music_________-_Mary Ruth Wham, Vernon Hickman

Costumes_-_-_-_-_-_ Gertrude Martin

Decorations -_-_-_Herbert Main (ch.), Osborne, Tanner

Collins and Bratton

Dances_-_-_-_._- Rachel Douthett

Program____ Wolff, Mrs. Borst, A. Townsley

Marshalls_-_ Irons, E. Hinton, $W$. Boyer

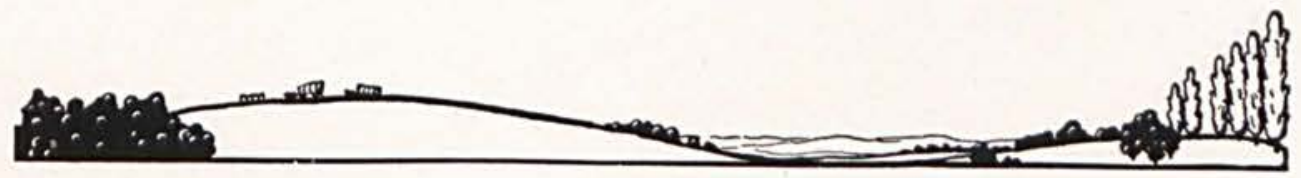

Eighty-five 
C E D R U S

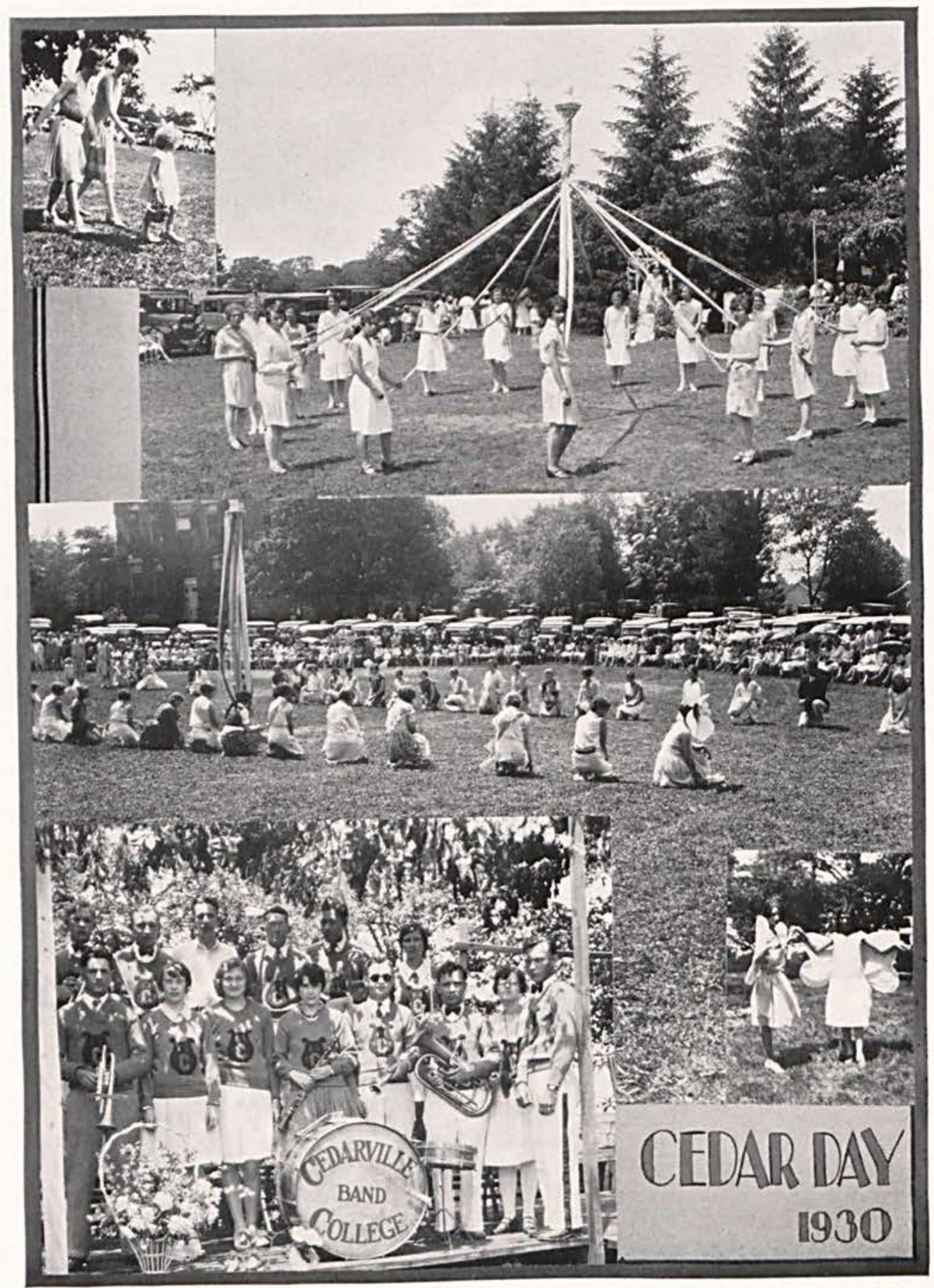

8 


\section{Baccalaureate Service}

As the music pealed forth in the Presbyterian Church, Sabbath evening June 1st, thirty-eight graduates marched down the aisle and took their places. After the Invocation, Scripture reading, and music by the College Girls' Glee Club, Dr. McChesney delivered an excellent sermon, with advice to these young pople who were so soon to step out into life for themselves. Following the message, Mrs. Corry rendered a vocal number. Then the many students and friends departed thinking of the things that are in the future.

\section{Commencement}

Friday morning, June 6th, friends and relatives gathered in the Opera House for the thirty-fourth annual commencement. The Speaker of the morning was Rev. Percival Barker, D.D., pastor of Point Breeze Church, Pittsburgh, Pa., who brought some practical advice to those who were just setting sail into the sea of life. Dr. McChesney conferred the Degrees and gave a Farewell Address warning them of the dangers they would meet and urging them to always follow the paths of right.

\section{Home-Coming Banquet '31}

On Saturday Evening, February 7, the Cedarville College Home-Coming Banquet was held in the Alford Memorial Gymnasium. This event was especially enjoyed, it being the first since 1928 .

After the bountiful banquet our president, Dr. W. R. McChesney, welcomed the two hundred guests. Then Mr. Earl Collins, president of the Alumni held the Class Roll Call. There were present three members of the Class of 1900.

The After Dinner Speech was given by Prof. Paul Brees, A.M., Head of the Department of Public Speaking at Wittenberg College. His topic was "The Mission of Mirth."

After the banquet quite a vast audience witnessed the Antioch-Cedarville game in which the visitors won by the narrow margin of two points.

C. F.

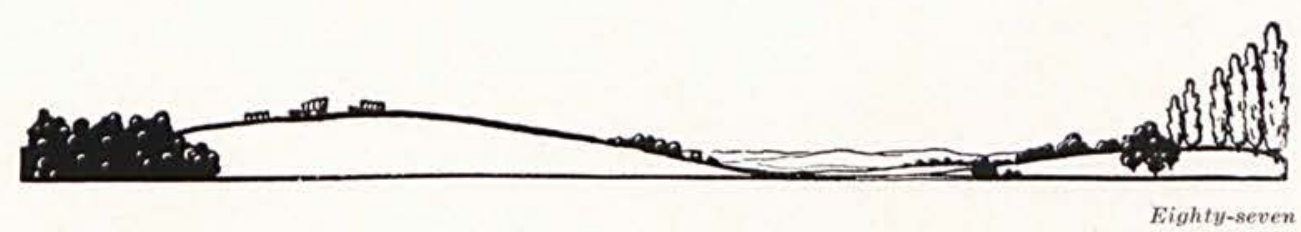




\section{Mother-Daughter Banquet}

Friday Eve, May 9, '30, a delightful Mother and Daughter banquet was held in Alford Memorial Gymnasium. This is an annual affair held under the auspices of the Y. W. C. A. After the banquet consisting of:

\section{Cocktail}

Chicken Patties

Mashed Potatoes

Peas and Carrots

Pocketbook Rolls

Butter

Pineapple-Cheese Salad

Angel Food Cake

Ice Cream

\section{Coffee}

The following program was enjoyed:

Toastmistress_______frances McChesney, President Y. W. C. A.

Music Edward Irons, George Gordon

Welcome Josephine Auld, Pres. Y. W. '29

Response Mrs. Wm. Marshall

Music Irons and Gordon

"Mother" (composed by Geo. Davis, '30) Dorothy Angevine, Faculty Advisor, Y. W. C. A.

Music Irons, Gordon

Address Dean Voight, Ohio University

C. F.

\section{President's Reception}

Dr. and Mrs. McChesney's reception for the students is a pleasure which we anticipate every spring, and we can safely say we are never disappointed. Last year it was an unusually happy occasion. Our President and his wife have the faculty of making one and all feel quite at home. The lunch served to a large number of guests was particularly delicious. Later in the evening we sang the old songs and new songs, and everyone carried home the impression of a happy and memorable evening spent in an ideal home.

S. M. C.

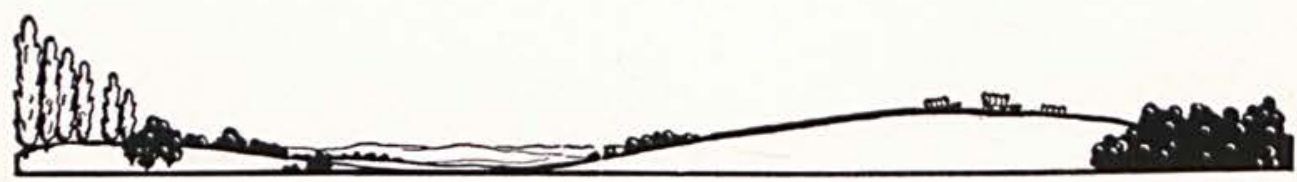

Eighty-eight 


\section{Committal Service}

Our Committal Service this year was indeed lovely and impressive. It was arranged by Frances McChesney, president of Y. W. C. A. of '30-as a Thanksgiving Committal Service. It was held in the Presbyterian Church. As a special feature a half hour organ recital was held before the opening of the service by Mr. Marion Hostetler.

The girls, dressed in white, entered the darkened church singing the processional hymn. This year's president Carmen Frazier, opened the service with the lines (arranged by Miss McChesney):

Hope giveth us

Another year

Adventurous

To follow the climbing good

By thorn and beast withstood

To heights of brotherhood.

God giveth us

Another year

All luminous

With him our shining source

Divine redeeming force

Of life's bewildered course

Still charioteer.

Then the program continued much as the Committal Services have continued for a number of years in Cedarville College Y. W. C. A.-with the old members' testimonies; with the pledging of the new members; and then lastly, the candlelighting service in the participation of which every girl is always thrilled and inspired. At the close of this part of the Service a beautiful bouquet of flowers was presented Miss McChesney for her splendid contribution toward the success of our Service. Then came the recessional with the girls carrying their lighted candles and singing the Y. W. hymn "Follow the Gleam."

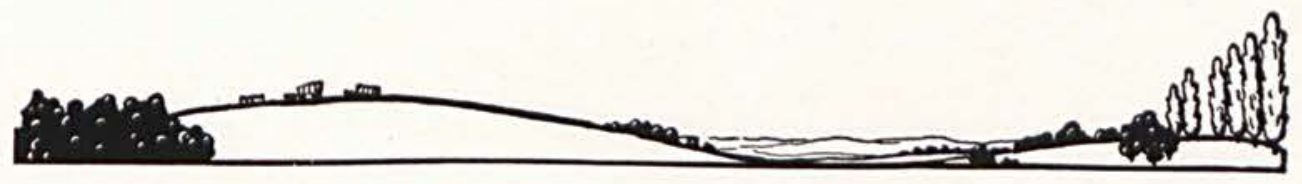




\section{Junior-Senior Banquet}

The Junior-Senior Banquet in honor of the class of 1930 was held Wednesday evening, May 7, at Houston Inn, South Charleston.

\begin{tabular}{lcr} 
& \multicolumn{3}{c}{ MENU } & \\
Chicken Croquettes & Fruit Cocktail & Mashed Potatoes \\
Hot Rolls & Peas & Jelly \\
Ice Cream with Strawberries & Perfection Salad & Cake
\end{tabular}

Following the banquet the very enjoyable program was presented:

Toastmaster

Vernon Hickman

LIFE

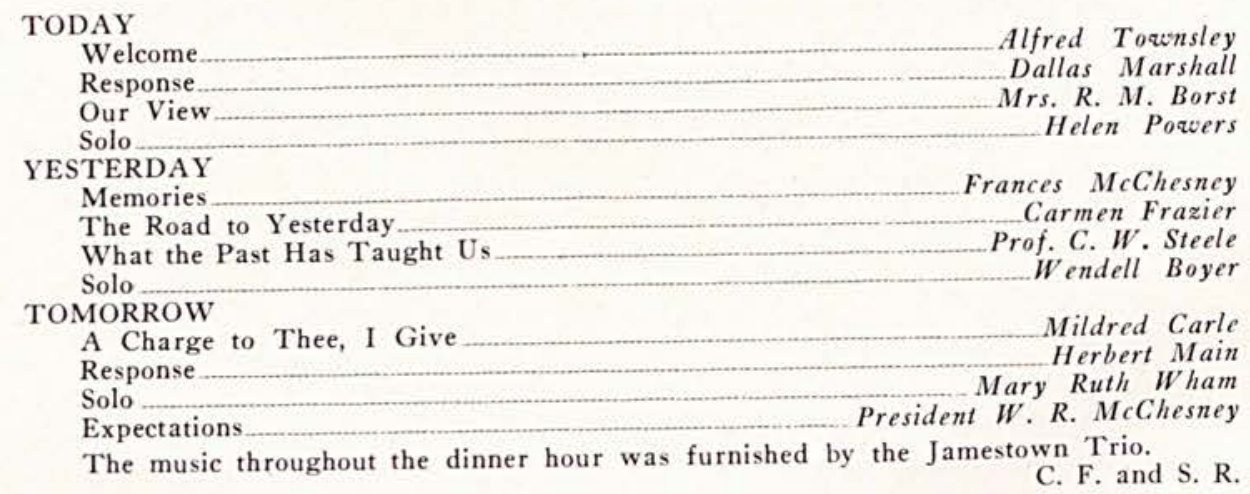

\section{Waffle Breakfast}

We are very proud to know and to have the world know that we have added a new number to the list of Annual College Events. It has been for the Y. W. C. A. as well as for other organizations and for individuals a hard year financially. But it would have been harder had it not been for the Waffle Breakfast. Yes, it was a social and a financial success. It was held on a crisp Friday morning in November at Miss Ruth Marshall's home from 7 to 9 A. M. Considering the early hour there was a surprisingly large crowd out. Many of the college fellows came out (about 8:30) and partook of the hot waffles, sausage and coffee. About sixty persons were served. Dr. Mac was there. Calling for a second helping he said, "Your Waffle Breakfast seems to be quite a success. I propose that it be made an annual affair."

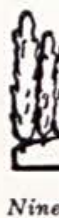




\section{Riproarin' Weddin'}

$\mathrm{T}$

HE home of Miss Doris Swaby, north of town, was a scene of a "Riproarin" Weddin'," Thursday evening, April 9, 1931, when the ceremony uniting Miss Rosebud Delicatessen and Mr. Archibald Hercules Headlight in the Holy Bonds of Wedlock was rudely disturbed by a rejected suitor, Mr. Joe Foster, and his gang of would-be desperadoes from Cedarville.

It was one of those lovely evenings in April when sudden calamities occur. Twilight had stolen down upon the country home. Everything was in readiness for the wedding - almost. Downstairs, the tables were set; the chicken simmering on the stove; the salad set aside to cool; the ice cream packed away in the cellar; the bridal flowers delivered and placed in a cool place; the bridal bower in the living room waiting invitingly; in the parlor the few early guests gathered idly gossiping. Upstairs was the flurry and excitement common with weddings. There was much excited questioning and directing, and much suffering as the stronger sex struggled with Tuxedos, and much anxiety as responsibility settled on inexperienced shoulders. Convention was overlooked. Both sexes mingled freely in the dressing rooms. It was not an unusual sight to behold a dainty Miss buttoning a perspiring gentleman into a stiff bosomed shirt, adjusting his suspenders, tying his shoe, etc. There was small talk of the gang's threat to "Bust up the weddin'."

Suddenly the hub-bub inside subsided with a "WHOOP!" from the outsidesubsided to break out anew in a changed atmosphere. The ladies paled or giggled hysterically; the gentlemen muttered behind their smart mustaches. The gang was attempting to carry out the threat. However, there was not undue anxiety for precautions had been taken against uninvited guests-in the way of locked doors and windows. Thus, the dressing went on until a scream from a far room stilled the hub-bub once more. The unwelcome visitors had found an unlocked window and, swarming up over the porch roof were making a triumphant entry with shouts of victory. Then indeed was the wedding party dismayed. The bride trembled. The minister, always a retiring, unassuming little gentleman rushed to the defense, waving aloft his white carnation. He grasped the sill of the raised window, crashed it down, well-nigh fracturing the skull of one ne'er-do-well who, unaware of the pending danger was following fast upon the heels of his predecessor. The fast following gang, however, soon routed the Reverend Gentleman, who dismayed at his attempted assassisation retired to think it over. The gang meanwhile had gained entrance and its members had arranged themselves about the bridal bower where with loud laughter and rude jesting they awaited the ceremony.

The wedding proceeded as if nothing had happened. Just before the processional Miss Nina Stevenson sang "Because" and "I Love You Truly." These numbers were boisterously applauded by the intruders. Then to the measured beat of the Wedding March played by Miss Lenora Skinnel came the processional. First came the ushers, Messrs. Martin and Swaby; then, the little flower girl, Miss Lois Cultice; then, the little ring bearer, Master Martha Lackey; then, the bridesmaids, Misses Bradley, Auld, McLaughlin, Waddle; these were followed by the Maid of Honor, Miss Rachel Douthett, lovely in pink, carrying pink and white sweet peas; lastly, came the bride, (Miss Helen Powers) upon the arm of her father Dr. B. Elias. She was more than lovely in her white georgette gown and veil. In her arms she carried a huge boquet of White Madonna Lillies and white sweet peas. The wedding party was met at the

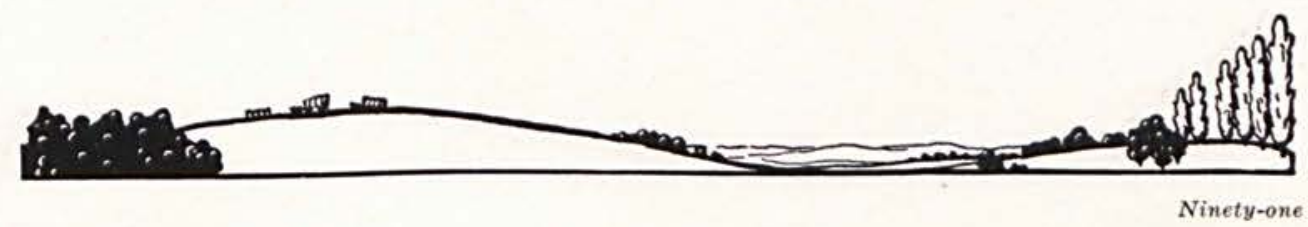




\section{E D R U S}

altar by the groom, (Miss Mildred Carle), the best man, Mr. Sarah Rumbaugh, the minister, Mr. Carmen Frazier, ushered in by Messrs. Chance and Marshall.

Amid jeers, comments, and coarse laughter the ceremony commenced. The Reverend Gentleman, realizing the momentousness of the occasion, exerted all his oratorical powers and, though having to pause a number of times to await silence, he concluded the ceremony and pronounced the couple husband and wife. With a sigh of thanksgiving the friends and relatives realized the intruders had failed to make good their boast. Evidently they were catering to the inner man-they had been promised dinner upon good behavior.

The friends extended the couple hearty congratulations. The would-be desperadoes expressed the intention of kissing the bride, but apparently they lacked hte boldness they had at first assumed.

A delicious dinner of creamed chicken, mashed potatoes, creamed cauliflower, silver and gold salad, Angel Food cake, — coffee was served. (Score one for the visitors. They stole the ice cream.)

\section{Fanning-Tanner}

A very quiet but impressive wedding ceremony was witnssed by members, friends and relatives Thursday evening, April 10, 1930, when Miss Dorothy Fanning and Mr. L. Tanner were united in marriage-the ceremony taking place at the home of Miss Ruth Marshall, the Reverend Frances McChesney officiating.

The dining room and living room were beautifully decorated-a yellow and white color scheme being carried out. A lovely bridal arch, built in the living room served as the altar.

Preceding the ceremony Miss Mary Ruth Wham sang "I Love You Truly" and "O Promise Me." Then the strains of the Wedding March marked the entrance of the processional. Down the winding stairway it came; first, the ushers, Messrs. Carle and Kirby, Followed by the little flower girls, Misses Bishop and Badstuber; then preceding the bride's attendants was the little ring bearer, Master Jean Morton; then the bridesmaids, Miss Auld, Mrs. Betty Graham; then the Maid of Honor, Miss Hilma Raisenen; lastly, came the bride leaning upon the arm of her father, the Hon. D. Wolfe. The bride was lovely in white silk crepe and long floating veil. She carried a bouquet of white roses.

At the altar the bridal party was met by the groom and the best man, Mr. G. Martin and the minister, these being ushered by Messrs. Marshall and Tobias.

After the ceremony a delicious luncheon was served the guests. Miss Helen Powers, finding the ring in her piece of cake was proclaimed the bride for ' 31 .

C. F.

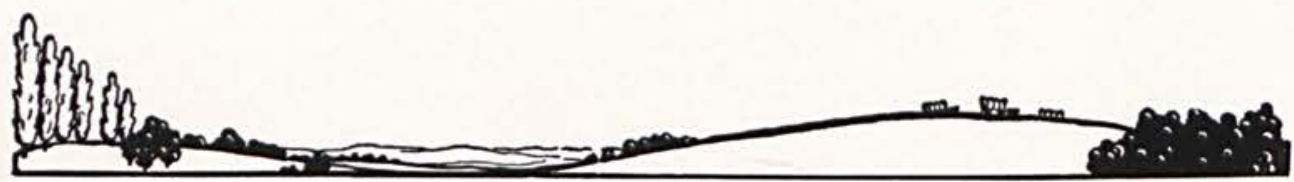




\section{E D R U S}

A $\mathrm{S}$ all Junior Classes must raise money to banquet the Seniors, and as the Class of ' 32 is not an exception to the rule, it also had to secure some means whereby it might fulfill its duty and so it was decided that the class should present a play. Realizing that they must choose something above the ordinary in order to keep up with the College's high standard, they decided to give a comedy, "Old Lady 31" by Rachel Brothers. They were fortunate in securing the services of Esther Smith Schick, to whom the Juniors owe their success. The play was presented before a capacity house on Wednesday evening, April 8, 1931, and its success was apparent from the first. The lines were well spoken, all responded to their cues, and as on later remarked, "Everything went lovely."

Wilda Auld with her meekness and Ed Hinton with his slow drawl acted the parts of Angie and Abe to perfection. The lovers played by Ruth Marshall and Ed Irons, furnished the comedy; and the necessary romance was well taken care of by Rachel Douthett and Henry Iddings, the former as Mary and the latter as John.

In all, as the theatrical critics would say, it had an all-star cast, and was worthy of anyone's time to have seen it.

S. M. C.

\section{"Old Lady 31"}

Angie Wilda Auld

Abe Edgar Hinton

Nancy Lenora Skinnell

Mrs. Hammans Sarah M. Chance

Sarah Jane Martha Waddle

Abigail Gertrude Martin

Blossy Ruth Marshall

Mary Rachel Douthett

John Henry Iddings

Samuel Darby Edward Irons

Mike Donald Allen

Elizabeth Eloise McLaughlin Granny Ruth Bradley

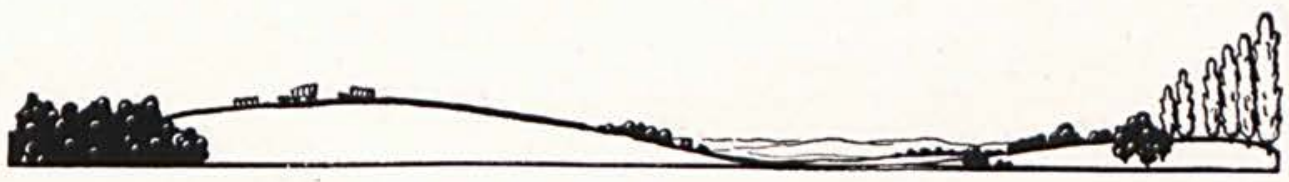




\title{
C E D R U S
}

\section{Cedrus Staff Play}

\author{
"MERTON OF THE MOVIES"
}

The Cast

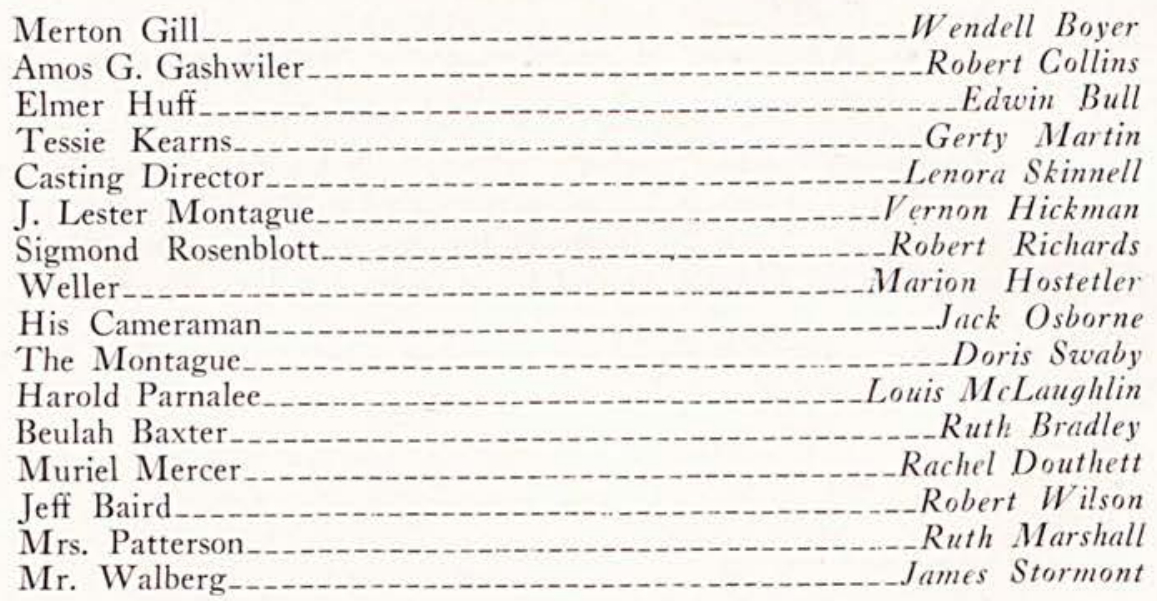

Would you like to be a great movie actor? Just ask Wendell Boyer the road to success. He was only a small town clerk but he had "big time stuff." With the clever directing of Robert Richards, and the feminine diplomacy of Doris Swaby, his name was soon made famous.

\section{Minstrel}

The Cedarville College Minstrel, the big show boat of fun, is given every two years. The year of 1930 was the scheduled year for it. The year of 1930 marks an advance in the displaying of unknown and unheard of talent.

The minstrel this year was something out of the ordinary as minstrels go, due to the talent displayed and due to the spirit and energy displayed in preparing for it and giving it. The cast had more fun in presenting it than the audience did in seeing it.

Under the able leadership of our interlocutor, Professor Borst, and the wild antics of our super-end men Shorty Kinnison, Henry Iddings, Bob Bratton and Robert Wilson. A barrel of fun was unearthed on the nite of May 1, 1930. We wish to congratulate and thank the male and also some of the female student body for the wonderful spirit shown in the presenting of this bit of high class showmanship.

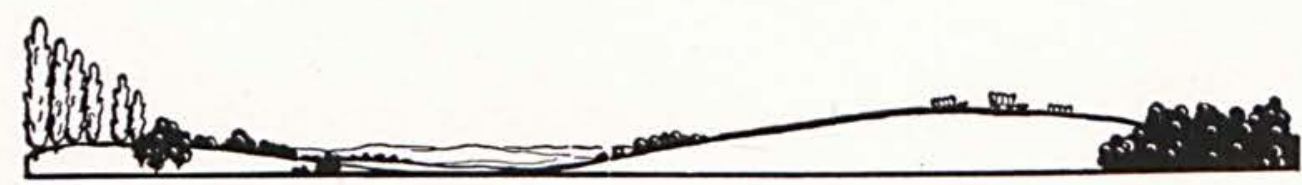




\section{Diary 1930-1931}

September 10-The lid's off-Registration- "I'll pay as soon as father sells his hogs"-assignments-speeches-"Aren't the freshmen little?"

11-Y. W. \& M-eating meeting.

12-Waterworks finishing in the mud.

13-Doctor Borst chapels with two verses of Proverbs.

14-M. E. Nutty party. M. E. Minister's first sermon (not at the party. P-jamma P-rade.

15-U. P. Social. Martha W. Silent. Rain. Dobbins-Jamieson youknowhat.

16-Footballers footballing.

17-Only five freshmen frails.

19-Borstmen vs. Orrmen. No decision.

21-One Frosh, Fat Mills, shorn.

22- The other Froshorn. Iddings arrives too oily. I mean early.

23-Marion late to orate. Studes trek to Dayton Air Fair.

24-Jurkat puts history class in bread line.

25-Hep meeting. Waldemar loses pompadour.

26 - Cedrus groups snapped at.

27-Candlite football at Zinzinnati. Flunked our night work.

29-“Aunt Lucia's" Miss Francis steps in from Rhome Fohk.

$30-$ Frosh-Soph officers elected. Is this necessary?

October 1-Fresh farm food at Frosh farm feed. Juniors descend on Douthett's.

2-Presbyterientertainment. Olympic games. Seniors slumber at Nagley's.

4-Jackets at Otterbein. Score worse than it otterbeen.

5-Y. M. at Columbo. Indiana-OSU mellee.

6-Willie Gormley's appendix in trouble.

8-Senior chicken carving at Power's. Swaby Soph. supper.

9- "Aunt Lucia" entertains half a house.

10- "Aunt Lucia" still here. The old gal was about all in though.

11-Early morning football. Six all. Borst woke 'em and Urbana put 'em back to sleep.

18-Wilmington wins. And so on far into the years'

22-Mlle. Angevine goes to Toledo teacher's meet.

24 - High School takes Bath-Township.

25-We play best in the afternoon. Rio licked first time in records. Thirtyfour and a goose egg.

27-Rev. Blair of Korea speaks. 


\section{E D R U S}

30-Femmes furnish frolic at jim. Gypsy Sprinkle prettiest. Um. Fudge and Schmidt clevah.

November 2-Boys' Bible reading hoax. Saxist gets surprise prize.

4-Mr. Cooper leaves Columbus. Mrs. Cooper comes to Dox. Y. W. plays Tag. Mills' gravel pit freshfeed. Foster calls Madame Burns and hoofs from Solon.

6-Gordon, Allen submerge sedan in Clifton creek.

7-Alumnustewart speaks on "Be Prepared. YW-affle eat. Wilmington wins, 13-0. Musical Mexicans at Opera.

10 -Cedrustaff picks play- "Berton."

11-Lost to Urbana. Any thing can happen now.

14 -Borst wins one. Generals H. S. team for ill Orr.

$18-$ Y. W. candles and committal.

22-Morehead, 7-0. And the suits go into mothballs.

$2+$-Rev. Schmidt speaks.

25-Second years gather at Garlough's. Thanksgiving vacash. at 12 . McCoy Franklin, Dr. White, Herbie Main speak. Variety.

27-Turkey Day. White meat hot. Weather cold. Few go to 'Force.

December $1-$ End of parole.

3-Lecture course. Lecture, of course.

4-Cedrus play, "Merton of the Movies." Good Hope boy makes good and whoopee.

9-Rio here. Avalon burns.

10-Antioch's Broda on League of Nations.

11-Enter, the Camelot scourge.

12 - Handed it to Hamilton.

13 - St. X. Xceeds our fears. 23-42.

15-Fra Lust in town. O. A. Dobbins talks on Holy Land. Some hair cut.

16-Dropped a game to U. of D.,

Twenty-two to twenty-three. Pome.

18-All over at noon. Hard times holidays.

January 6-Opening of scene two. Girls, boys, split with Springfield B. C.

7-Selma whips Roush's Ross.

12-Rev. Carl White in chapel.

13-We play Wilmington, Wilmington plays ball. Prof. Kenfield's cagers capture contest.

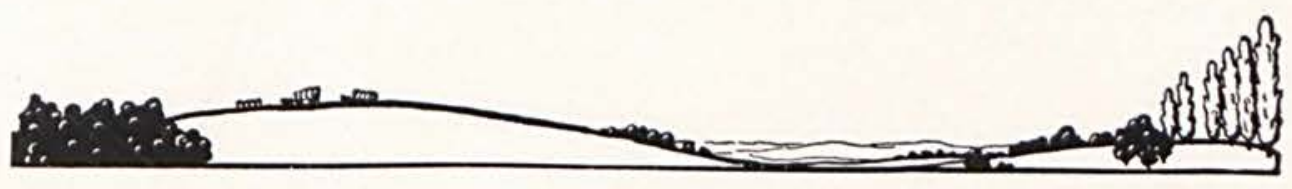

Ninety-seven 
16-Boys-Urbana. Girls-Alumni.

19-Mrs. Cherry sings in chapel. Exam. scheds. out. H. S. beats the great Selma.

20-Jackets tail-spin Dayton Flyers. Haven't we done that before?

22-Seniors spread at Hickman's. Juniors go guzzling to Gun Club.

23-Another athlete at Borst's. "Carl Max."

24-Defiance. Nice trip tho.

27-Crams, exams, d- - .

28-Blistered by Bliss.

30-Wilberforce. Skinned 'em by one point.

31-Over at Antioch.

February 3-Grand opening of second act. Exeunt Schmidt and Grant. Enter Foster, Taylor, White. Fair exchange.

5-Prof. Steele ill. But Senior waffleslumber party goes on.

6- Half Day of Prayer. Other half at talkies.

7-Chickenless Homecoming. Ours, $20-4$ at half. Theirs, $24-22$ final. Must have been the salad.

12-International confab at 'force.

13-Rolling down to Rio. 33-33.

14-Morehead more ahead than we. Brown's canary contest closes.

19-Boys battle Bliss. Girls gang gives glee gab.

20-Cow drills and rumba at Charleston. Home town boys and red head

22-Cho-choo-Sedan smash at 2.00 A. M. on Main St. Mrs. Grundy mistook them for C. C. co-eds.

25-Juniorations at Waddle's.

27-Bims beat Bath.

28-Old Mill unpadlocked. H. S. femmes finish in the money at Xenia.

29-Christine, Nina, vie in vamping Vermin.

March 3-Another Sedan. Belgian Congo Missionary.

4-Urbana overtime. "Ideal Girl" in Y. M. Few ideals at Y. W. Big snow.

6-Wilberforce closes season. Mary Rose Stock Co. opens season.

9-Philo debate, "College next year?" Hot dog snow stag at Cliffs.

12-Marine Markle makes music.

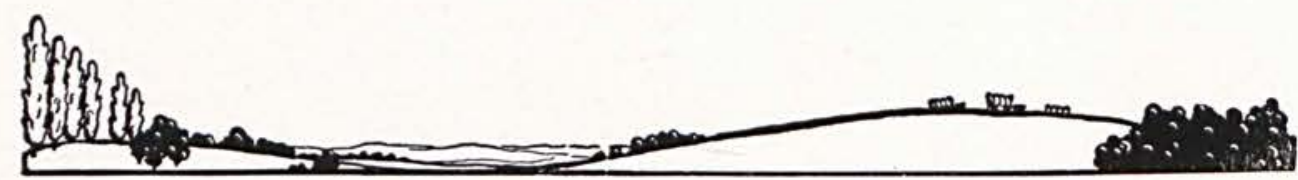


13-Nina, Mrs. Corry sing Irish tunes.

15-"Winning with Wilma," or "From Oil Station to Ice Wagon in Three Weeks."

17-Markle on "Haiti." Smiley switches from Irene to Irene.

18-Mrs. Jenkins-“Making your wish come true"-Tsk, tsk.

20 - Stock Co. packs 'em in for school kitchen berefit.

26-Basketballetters.

31 -Rockne killed in Kansas.

April 1-H. S. Jr. Cls. ply.

2-Easter holiday.

5-Easter bonnet, lily and egg day.

6-Easter recess over.

7-Did I mention Easter?

8-Taylor beat Pitchin. "Old Lady No. 31" simply slays us.

9-Mock wedding. Mock ice cream. Boys eat and walk. Steele gets a little buggy.

11-Morehead makes more hits. 7-4.

15-Little boy whips big boy. Dayton eased 5-4.

19-Girls read Bible. Preston off side. Otto autos for judges.

20-Juniors ramble to cliffs in rain.

22-Austin Black wants us to go touring. In an Austin?

24-Wilmington B. B. Our little flash was so tinder that we were bruised. We were so weak and puny.

25-Wilberforce forces in a few. 8-6.

27-Soft ball well under way.

Doris Swaby

Irene Tobias

Elmo Jurkat

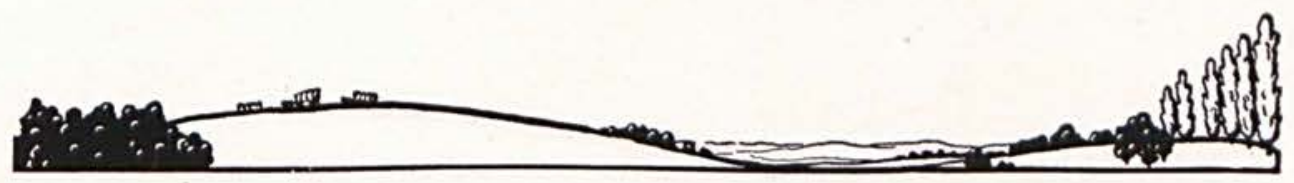

Ninety-nine 


\section{Jokes}

Prof. Davis: Define angular velocity.

Bull: Angular velocity is the velocity of something that goes round and round and never gets anywhere.

Prof. Davis: Give an example.

Bull: Fudge.

Miss Wolfe: Define a monologue.

Kenfield: A monologue is a conversation between two people, such as Miss Angevine and Ballard.

Mother: What do you want for your birthday, darling?

Bill Waddle: I wanna have one of those "rich man's playthings" I've read so much about.

First Convict: When does you all leave here, boy?

Iddings: The first.

First Convict: De first of when :

Iddings: The first chance I get.

Jack Osborn: Da you repair cars here?

Garage Owner: Yeah, but we don't do manufacturing.

Scott: Have you read "To a Mouse"?

Garlough: Naw. How do you get 'em to listen?

Mr. McLaughlin: Your studies are suffering, son. Do you need a coach?

Louis: No, Dad, a roadster will do.

Stranger: I represent a society for the prevention of profanity. I want to take profanity entirely out of your life and-

Marion H.: Hey, Dad. Here's a man who wants to buy your car.

Customer at Doc's: I don't like the flies in here.

Bob: Sorry, Sir, there'll be some new ones here tomorrow.

Edith Foster: He is all the world to me. What would you advise me to do. Hickman: See a little more of the world.

Some girls let a fool kiss them; others let a kiss fool them.

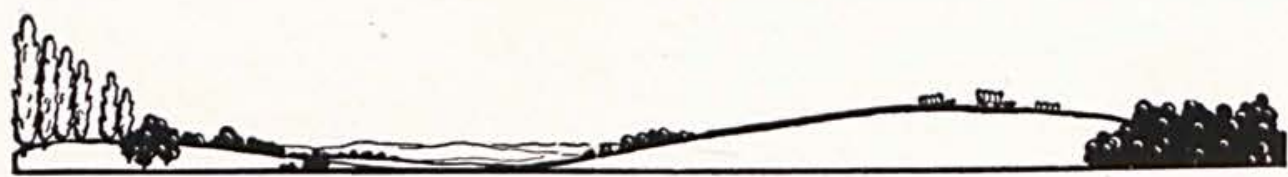




\section{Notice}

Our advertisers are the ones who really make it possible for us to publish our Annual. If it were not for their kindness and their faithfulness it would be impossible for us to publish any book at all. It is impossible for us to say anything which can come any way near expressing our thanks and gratitude.

However, we as students can show our gratitude for the good favor done us by returning to our advertisers a good favor. They are behind us students, so come on, what do you say? Let's get behind them.

We thank you, Advertisers, from the very depth of our heart and we hope that someday it will be our privilege to do something for you.

\section{Advertisers}

E. A. Allen

\section{Cedarville}

Cedarville College

Cedarville Herald

Richards Drug Store

The Exchange Bank

C. E. Masters

Ed Paine, O. M. Camp

Cedarville Lumber Co.

W. W. Troute

C. H. Crouse

Wolford's Garage

Home Clothing Co.

W. L. Clemans

\author{
Xenia \\ Jobe's \\ H-y Art Shop \\ Xenia Auto Necessity \\ Valet Press Shop \\ Woods Barber Shop \\ Xenia Candy Kitchen \\ Bijou Theater \\ The Criterion \\ Tiffany Jewelry Store \\ Adairs \\ C. A. Weavers. \\ Indianapolis \\ Stafford Engravnig Co.
}

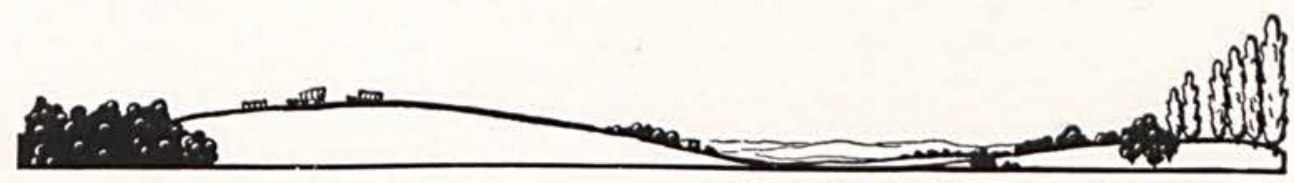




\title{
CEDARVILLE COLLEGE
}

\author{
CEDARVILLE, OHIO
}

$\mathrm{T}$

HE thirty-eighth year of Cedarville College will open September 9, 1931. An unusually large number of young people are seeking information and the outlook for an increased Freshman class is very bright.

Cedarville College offers courses for practically every pursuit in life. The entire expense for tuition, books, furnished room, light, heat, and boarding runs from $\$ 386$ to $\$ 450$ for the year.

All young people who expect to climb to the top will find it absolutely necessary to have a college education. Cedarville College is a Christian institution. It has the commendation of four large presbyteries of the Presbyterian Church in southwestern Ohio. It is in a campaign to raise an additional three hundred thousand dollars for its endowment fund by 1934 and eventually to add to that two hundred and fifty thousand dollars more and to erect as soon as possible two buildings, a girls' dormitory and a chapel with offices for administration attached to it.

Cedarville College appeals to all Christian people of means who believe in a genuine Christian education to contribute liberally to the work of the college.

Catalogue and other literature will be sent free.

W. R. McChesney, President. 


\title{
STANDARD ICE CREAM
}

\author{
Goodness! \\ How You'll Like It
}

By far the most popular Ice Cream in Cedarville for the past 17 years. There must be reasons for this continued popularity.

Special and Fancy Creams and Ices for All Occasions

Richard's Drug Store

"Popular With the Students"

MAKE YOURSELF A'T HOME AT "DOC'S"

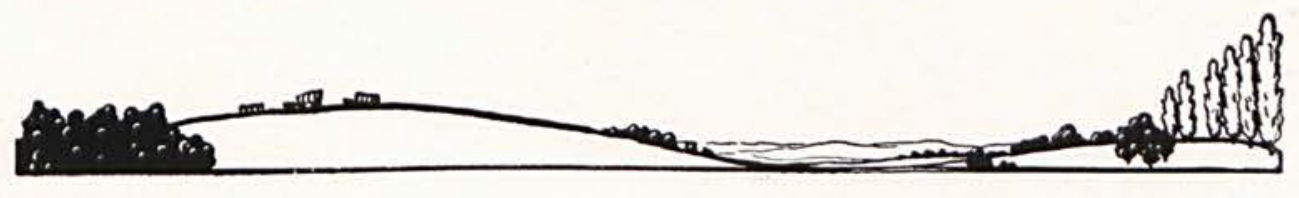




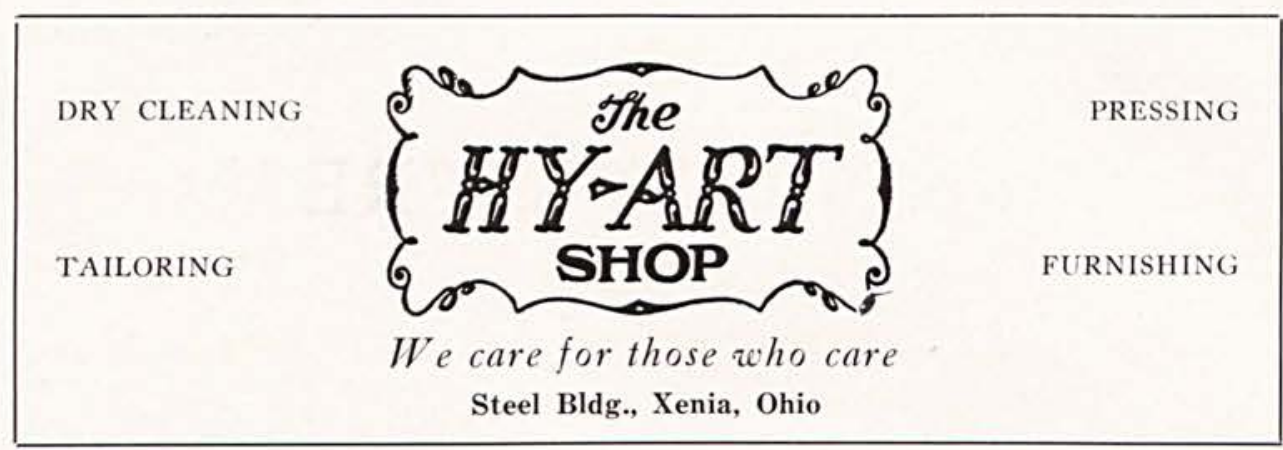

Miss Angevine: Have you read Kenilworth?

Harbough: No. I hate dog stories.

Mother: I'm afraid that Brenton is burning the candle at both ends.

Father: Huh! That boy has cut the candle in half and lit up all four ends.

We understand that Moorman thinks that his economic prof rides to class on a business cycle.

Eloise: What happened to Ballard?

Sarah Margaret: Drowned while skating.

Eloise: Fall through the ice?

Sarah M.: No. He fell down and spring came before he could get up.

Murray: I want a pair of corduroy pants.

Clerk: How long?

Murray: How long? I don't want to rent them. I want to buy them.

Kilpatrick: Where are you going?

Foster: Library. What are you going to do?

Pat: Oh, I'll get my date across the road. his pick.

We hasten to point out that while every man has his wife, only the ice man has

\section{THE CEDARVILLE HERALD}

\section{Commercial Catalogue}

Job Printing

LET US GIVE YOU AN ESTIMATE ON YOUR PRINTING

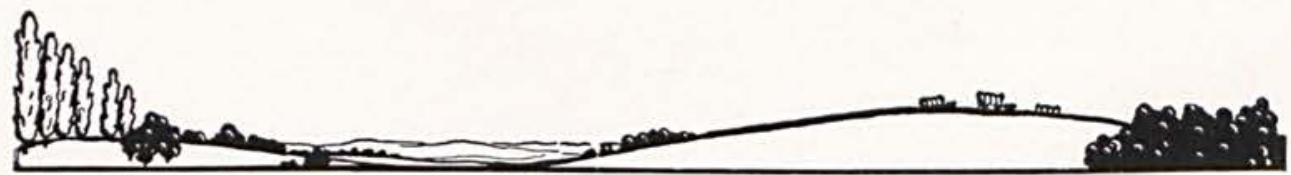




\section{E. MASTERS \\ Grocery and Meat Market}

Phone 2-44

Cedarville, Ohio

Hopkins: How can I make anti-freeze?

Dobbins: Hide her woolen pajamas.

Mills: What does Trader Horn call his mother?

Bennett: Mater Horn, of course.

Spencer: How did you even up with Prof. Keuhrman?

Bost: Oh, I handed him a hot retort.

Swaby: Do you keep all your love letters?

Elias: Sure thing. Some day I expect them to keep me.

\begin{tabular}{|c|c|c|}
\hline $\begin{array}{l}\text { Permanent Waving } \\
\text { Finger Waving }\end{array}$ & WOOD'S BARBER SHOP & $\begin{array}{l}\text { Marcelling } \\
\text { Manicuring }\end{array}$ \\
\hline
\end{tabular}

Ed Wood in charge of Beauty parlor

181 W. Main St., Xenia, Ohio

Taylor: How was the geology lecture?

White: Fine. I was rocked to sleep.

Rumbaugh: What are you going to do with your bathing suit next winter?

Curry: Use it for a book mark.

Douthett: I've got a standing date every Saturday night.

Hinton: How come? Engaged?

Douthett: No. Working in a store.

Dry Cleaning
VALET PRESS SHOP
33 S. Detroit St.

Xenia, Ohio

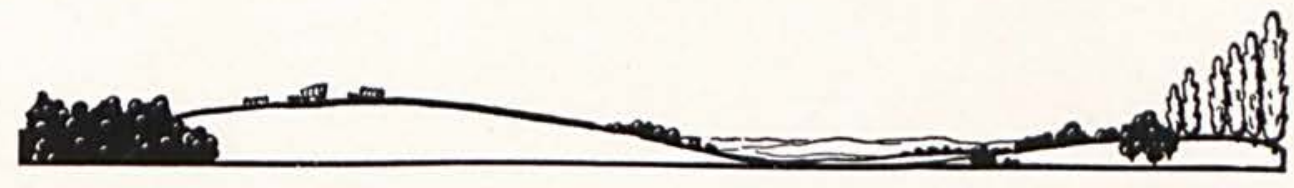




\section{THE CRITERION \\ "Value First Clothiers"}

XENIA

OHIO

Photographer: Your son in college ordered these pictures from me.

Mr. Kitchen: Well, well, they certainly look like him. Has he paid for them.

Photographer: No, sir, he has not.

Mr. Kitchen: Hum-m-m. Still more like him.

Cultice: Shall I tell you the joke about the cheerleader?

Lackey: Remember, no rah stories.

Miniature Golf

\section{OLD MILL CAMP \\ TEA ROOM \\ Meals-Short Orders}

Fifteen Cents

Love is an urchin,

A poor gutter rat,

Starved and anemic,

But happy at that.

Mr. Hostetler: Miss Rife, why does the state of Missouri stand at the head of mule raising?

Christine: Because the other end is too dangerous.

\section{A. Weaver Co.}

Fashion Park

Clothiers

$\$ 22.50$ UP
Xenia, Ohio

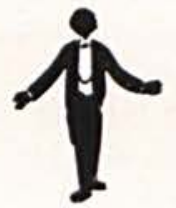

Experience, Equipment and Education make your work well done.

$$
\text { We have it }
$$

\section{WOLFORD GARAGE}

STORAGE OILS GREASES

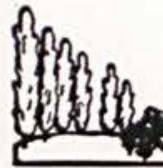




\section{THE "SWEETEST SPOT IN XENIA" \\ XENIA CANDY KITCHEN \\ Wonderful Candies - Lunch - Fountain Specials COME AND VISIT US}

Dutch Rife: Hello, Wendy.

Wendy: Oh, hello. I didn't recognize you with your clothes on.

Hinton: It's a great pipe. Thanks Pop. I see it's already broken in for me.

Papa Hinton: Yes-that's your birthday cake.

Nina: I am firmly convinced that man is made of mere dust.

Hickman: But not gold dust.

Fudge: Did you hear the story of the three aspirin tablets?

Skinnell: Huh?

Fudge: Did you hear the-

Skinnell: No.

Fudge: Maybe I should have said the three Bayers.

\section{CEDARVILLE LUMBER CO.}

Everything in Lumber, Millwork, Fence and Posts, Wool, International Farm Machinery and Repairs

Phone 33

Professor Steele: How many people are there in this country?

Joe Finney: Er-r-r-rlarger.

Professor Steele: Hurry, hurry. Every second you dilly-dally the number grows

Martin: How were your grades last semester?

Bradley: Jules Verne.

Martin: How's that?

Bradley: Twenty thousand leagues under the " $\mathrm{C}$ ".

No, Carmen, a coquette is not a small coca-cola.

\section{W. L. CLEMANS \\ REAL ESTATE-FARM LOANS}

Cedarville

Life, Health, Accident, Fire and Tornado Insurance

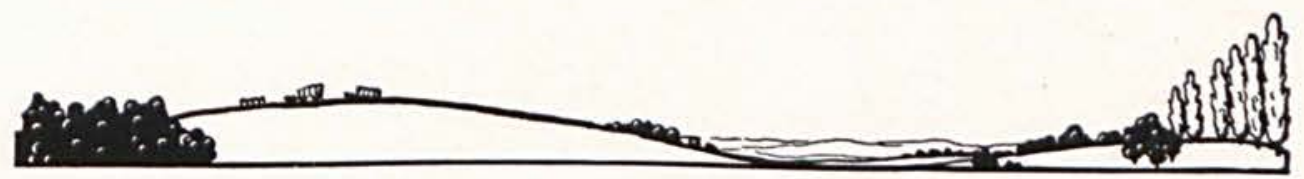

One hundred seven 


\section{THE EXCHANGE BANK}

Cedarville, Ohio

We solicit your account-four per cent on savings

Alfred tells us that the modern flapper is very quick on her feed.

Irons: I'm groping for words.

Roseberry: You don't expect to find them around my neck do you.

Mildred Carle tells us that some bath tubs are called "diamonds" because they are settings for rings.

Will sombody tell Mary Andrus that a polygon with seven sides is not a hooligan?

\section{BIJOU THEATRE \\ "The best of all talking pictures"}

Matinee Every Day 2:30

Xenia, Ohio

Martha Waddle: How did Albert Turner fall out of the airplane?

Bernice Bryant: His hat blew off and he jumped off to get it.

Officer: Why did you call me? Is this man annoying you?

Curry: No, but he is trying to get away.

Prof. Jurkat, in History: What is the latest date mentioned in your book?

Collins, thinking of his diary: Sunday night until four o'clock.

Doris Hartman: I don't tell everything that I hear.

Lucille: No, you haven't time.

\section{ADAIRS}

Furniture, Carpets, Stoves, Radios

20-24 N. Detroit St.

Xenia, Ohio

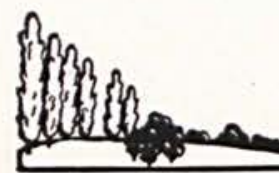

One hundred eight 
YENIA

\section{TIFFANY JEWELRY STORE}

It is hinted that the following statement was found on the paper of Helen Powers: The battle of Trafalgar was fought on the sea, therefore it is sometimes called Waterloo.

Borst: Name the three races of man.

Walter Boyer: Foot race, horse race and automobile race.

And again, if all the frosh were placed end to end at a banquet, they would reach.

\section{H. CROUSE}

GROCERIES AND HOME KILLED MEATS

Willis: Have you seen Ruth Marshall's new evening gown?

Eddie: No. What does it look like?

Willis: Well, in most places it looks quite a bit like Ruth.

Lady: I want some kid gloves for my ten-year-old daughter.

Sarah (at Penny's store): White kid?

Lady: How dare you!

\section{Improve Your Health With Good Eats TROUTE'S}

\section{CASH AND CARRY GROCERY}

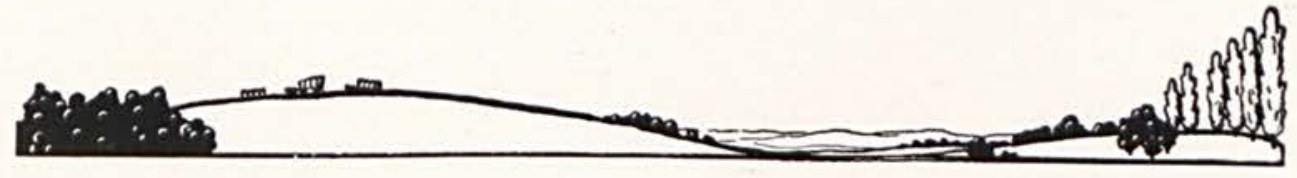




\section{When You Need Tires Take Advantage of Our Free Road Service}

PHONE 533

Dayton Tires, Gould and Delco-Remy Batteries, Quaker State and En-ar-co Motor Oil

\section{XENIA AUTO NECESSITY COMPANY}

T. R. McClelland

31 S. Detroit St.

R. J. CcClelland Xenia, Ohio

Collins: I hear that Lenora has parrots' disease.

Stormont: How so?

Collins: She repeats everything she hears.

Kenfield: What are you doing with your socks on wrong-side out?

Kitchen: Oh, my feet got hot so I turned the hose on them.

Bobbitt wants to know why he should use Ivory soap. Even the manufacturers admit it isn't pure.

Coach Borst: You must be the worst caddie in the world.

Caddie: Hardly. That would be to much of a coincidence.

It seems that some of the boys were at a certain show in Springfield.

Foster: What is the matter with Kenfield?

Murray: He forgot his glasses.

Marshall: I hear that Steele's courses are snap courses.

Choppy: Yeah, if you look sideways he'll snap your head off.

\section{For 1931}

We offer you a most carefully selected stoze full of quality merchandise at the lowest prices in ten years. You will find that the business trend is definitely toward

XENIA
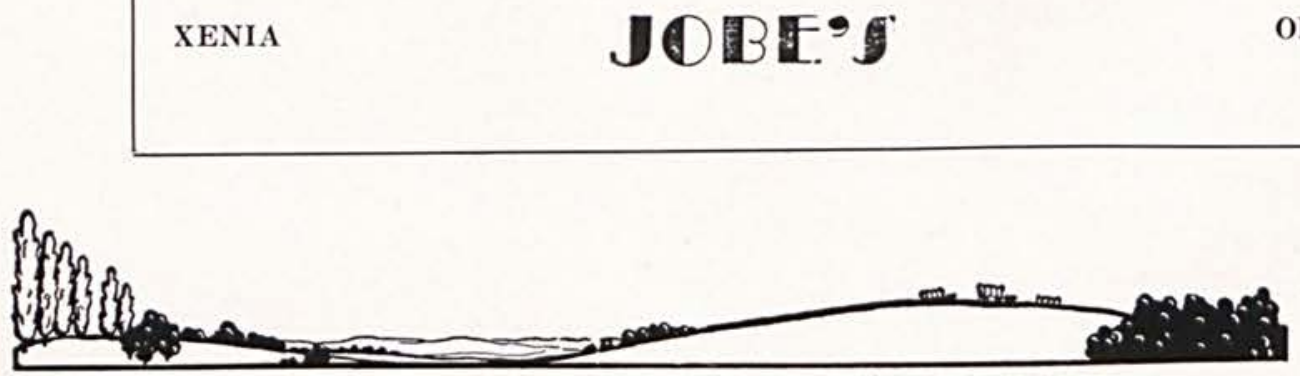


\section{Be good to your pocketbook \\ HOW?}

Consult

Phone 21

\section{E. A. ALLEN}

Coal, Fence, Paint, Farm Equipment

Dr. Mac (slightly aggravated): Listen here, young man, are you the teacher of this class?

Taylor: No, sir, I am not.

Dr. Mac: Then don't talk like an idiot.

Roseberry: What's the reason, Ruth, since you broke your arm ski jumping that all the boys are flocking around you?

Sprinkle: You see, that was my slapping arm.

We hear that Malcolm Finney holds an umbrella over his sheep when it rains so the wool won't shrink.

Albert: I am going to send my wife to the mountains for the holidays.

Irene: What holidays?

Alfred: Mine.

Murray: Let us journey to town, dear roommate.

Ballard: But my good fellow, I have nary pence.

Murray: I have a pair that you can wear.

Virgil Hughes: Mother, are sheep the dumbest animals?

Mrs. Hughes: Yes, my lamb.

\section{QUALITY CLOTHES AT REASONABLE PRICES}

Hats, Furnishing Goods, and Shoes for the Whole Family

\section{Home Clothing Company}

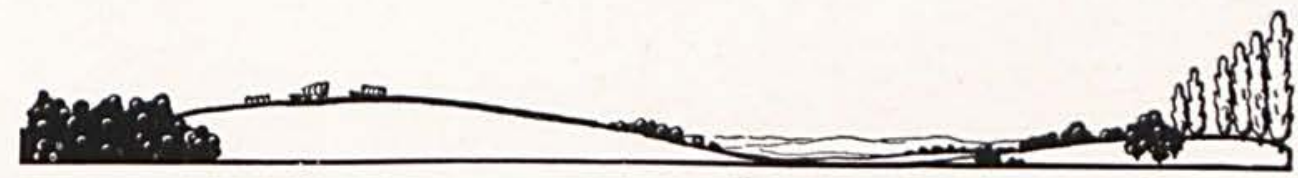




\section{E D R U S}

Foster: Do you know that chorus girls have a hard time?

Brenton: Yes, they do have to bare a good deal.

Prof. Steele: My boy, at your age I was up at six in the morning with the lark. Iddings: I don't care to keep a lark going that long.

Dr. Mac: What kind of leather makes the best shoes?

Bill Waddle: I don't know, but banana skins make the best slippers.

Sarah R.: Hopkins was the goal of my ambitions but-

Bernice: But what?

Sarah: Uncle Fred kicked the goal.

Curry: Young man, can I get into the park through this gate?

Little Boy: Guess so, lady. I just saw a load of hay go through.

Eddie: I'm writing a song.

Willis: Yes? What's the subject matter?

Eddie: It doesn't.

Mrs. McChesney: Do you know where the step-ladder is?

Eloise: Brenton had it last.

Mrs. Mac: Then it is probably in the pantry.

Hopkins: I suppose that you wish every year had 365 days of rest.

Mormon: Are you mad? Then I would have to work a day every four years.

Tobias: I see that Moses was a toreador.

Prof. Steele: How do you figure?

Irene: Well, wasn't he in the bull rushes?

Miss Berkley: My father has always given me a book for my birthday.

Lenora: My, what a wonderful library you must have.

Strange Girl (just introduced) : Somehow you seem familiar.

Albert: Good heavens, I haven't started yet.

Wilda: Marion told me a story last night.

Eloise: Did he tell it well?

Wilda: Well, he held his audience.

Mr. Waddle: Your B. F. talks too much. He rattles along like a Ford.

Martha: I know, Dad, but his clutch is so different.

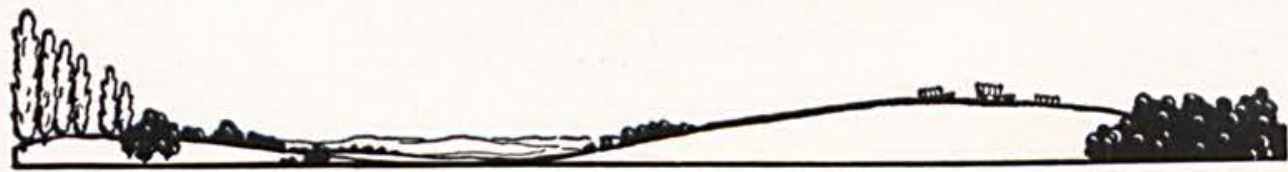


Dutch Rife: I have solved the mystery of what a hotel means when they advertise "rooms $\$ 1$ and up."

Garlough: What is it?

Dutch: I got one of the dollar rooms and was up all night.

Mildred: What was Sarah talking about?

Carmen: Business

Mildred: I know, but whose?

Prof.: Congratulations, my boy.

Irons: But you just said I flunked out in medical school.

Prof.: Sure, think of the lives you have saved.

Teacher: Canaan was a land flowing with milk and honey. Now what do you think a land flowing with milk and honey would be like?

Ballard: Sticky.

Nina tells us that Vernon is so silent that she is going to have him wired for sound.

Prof. Steele: Make a sentence using the word evanescent.

Iddings: Well, well, well, evanescent my old friend Charlie.

Mrs. Keuhrman: What lovely fleecy clouds. I'd like to be up there sitting on one of them right now.

Mr. Ditto: All right. You drive awhile.

Ballard: How long can a man live without brains?

Collins: I'm sorry, but I don't know your age.

Elias: Since Walter has been married I notice that he hasn't been running around so much.

Eloise: No, since the knot has been tied he hasn't so much rope.

Bost: Does your grandpa wear a full beard?

Bull: No, he is always careful when he eats.

Brenton: Marriage is a great game.

Sarah Margaret: Yes, but it always ends in a tie.

B. F.: How long before she will make her appearance?

Ma. Marshall: She is upstairs making it now.

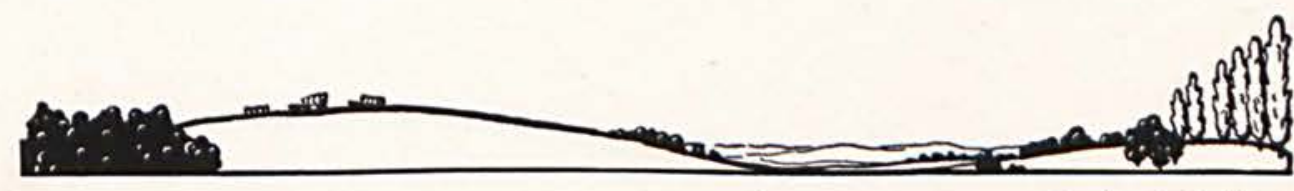

One hundred thirteen 


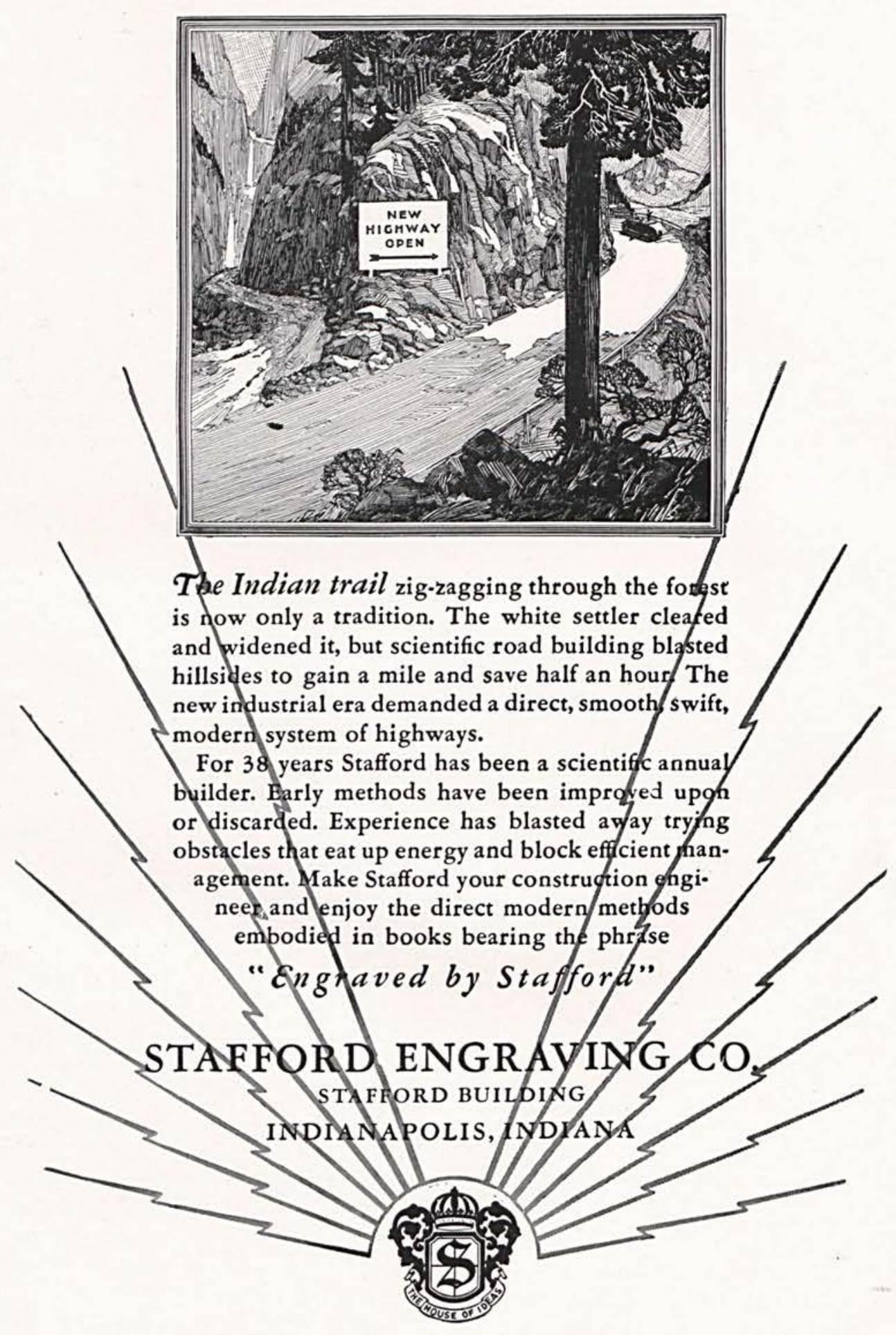

Man 
Autographs

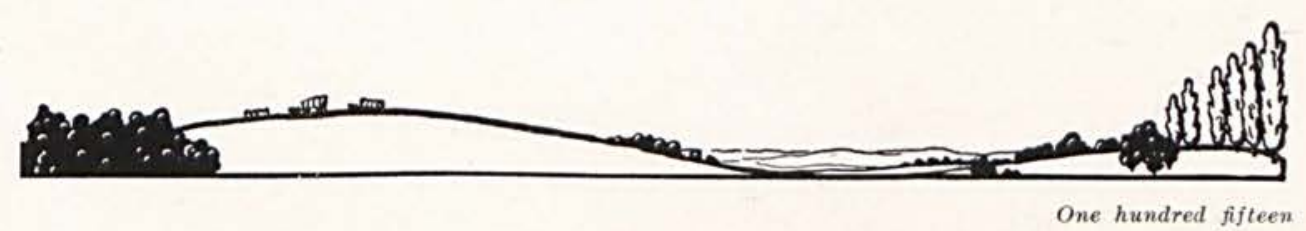


Autographs

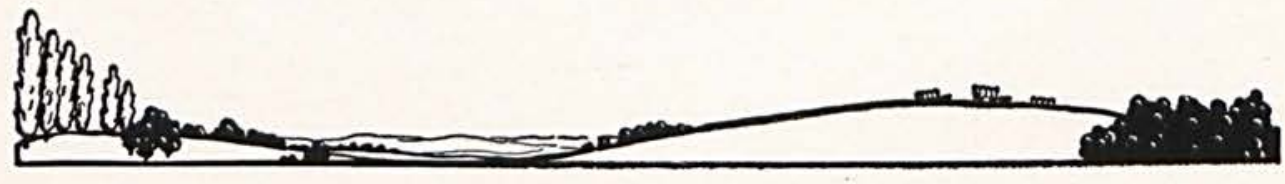


Memories

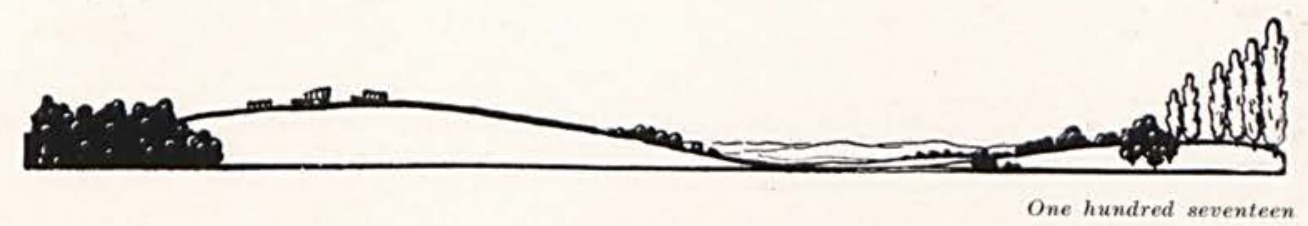


Memories

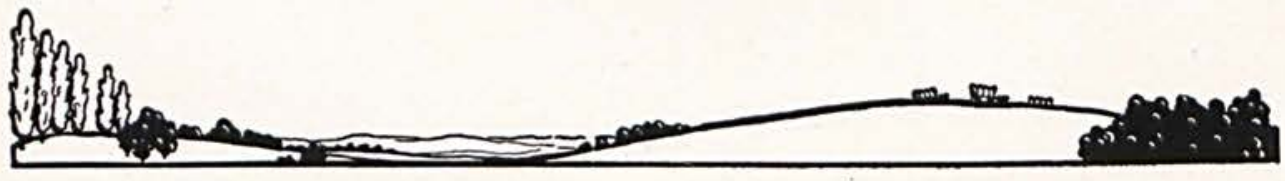




\section{Ending}

There comes an ending to everything And now it's time to say goodby

There is a meaning to the songs we sing As the merry moments fly

We want to thank you for everything

You make us glad we came to school

Good luck to you, we are sorry we are through

But it's time to go.

\section{"Oh, Goodbyee"}

Oh goodbyee, don't you cryee

For there's a silver lining in the skyee

Cheerio, old thing

Come on and sing

You'll be back some other year

So goodbyee.

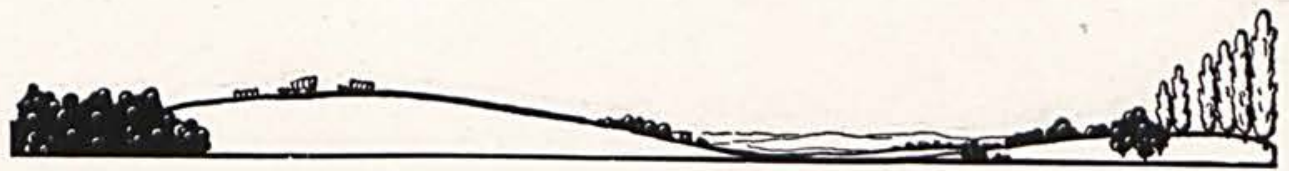



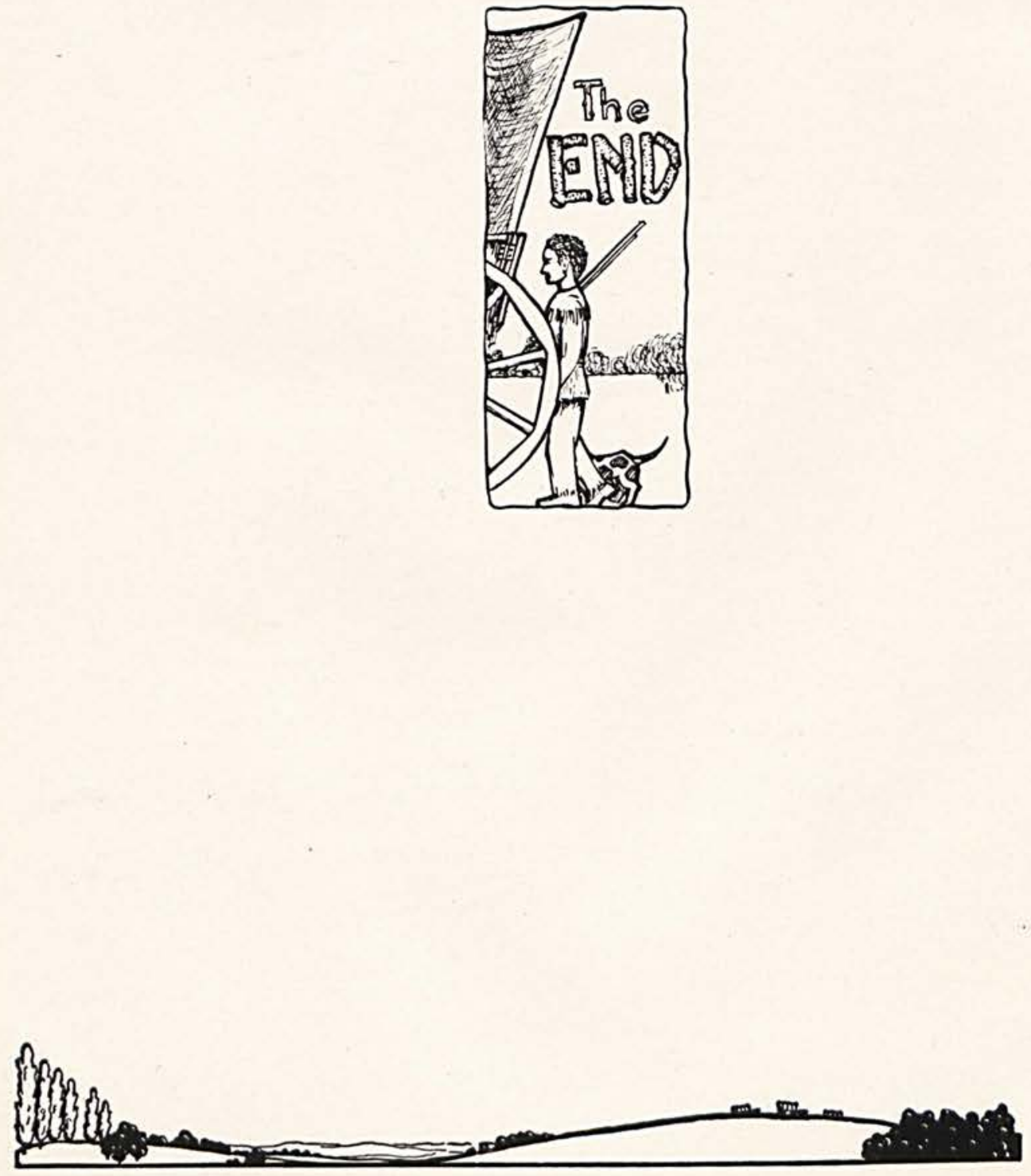

One hundred twenty 


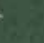



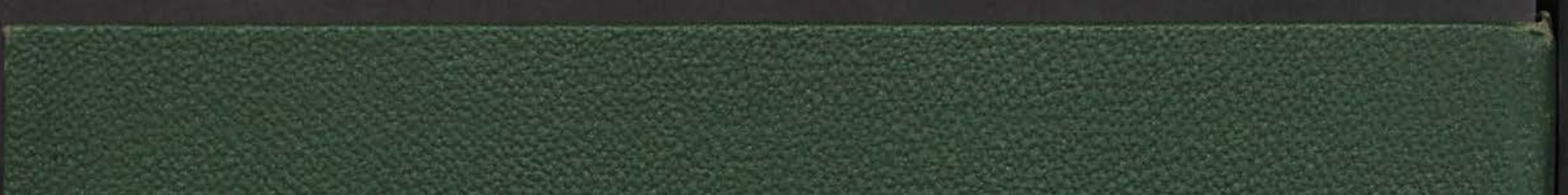

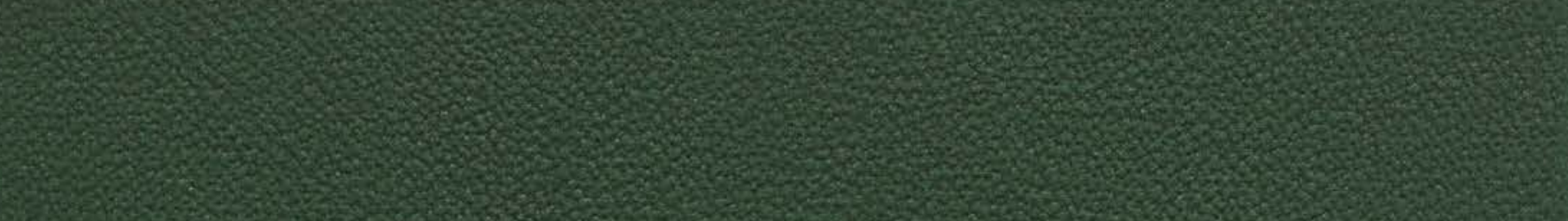

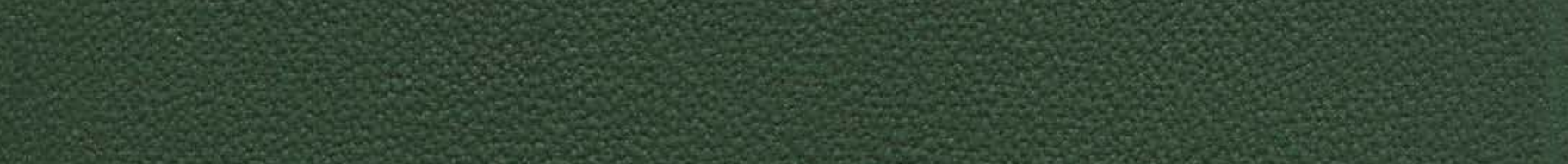

